1

2

3

41 = Department of Geological Sciences, Chiang Mai University, 239 Huaykaew Road,

5 Chiang Mai, 50200, Thailand.

62 = Department of Earth Sciences, University of Oxford, South Parks Road, Oxford, OX1

$7 \quad 3 \mathrm{AN}, \mathrm{UK}$.

8 Abstract

9

\section{Structural and tectonic development of the Indo-Burma Ranges}

By

\author{
C. K. Morley ${ }^{1}$, Tin Tin Naing ${ }^{2}$, M. Searle ${ }^{2}$, S. A. Robinson ${ }^{2}$
}

The Indo-Burma Ranges form an enigmatic mountain belt, with fragments of evidence for an early accretionary history (Jurassic Jade belt HP-LT metamorphism; Early Cretaceous ophiolites; highly deformed Triassic turbidites (Pane Chaung Formation, PCF); Kanpetlet Schists). It remains uncertain whether this early history involved collision of a microcontinent (Mt. Victoria Land, MVL), unconformably sealed by Aptian-Cenomanian limestones, or can be explained entirely as an accretionary-type ophiolite on the western margin of the West Burma Terrane (WBT). Complex deformation in the deepwater Triassic, Jurassic, Late Cretaceous, and Paleogene deepwater sequences is replaced in the Late Eocene-Early Oligocene by molasse deposition. These events mark closure of the Neo-Tethys ocean between India and the IBR/WBT, and the onset of major dextral translation $(>2000$ km, 40 Ma-Recent), between the coupled India/IBR/WBT region and Sundaland. In the Late Miocene-Recent major transpressional deformation affected the IBR and Central Basin of the WBT. The late deformation events, sedimentary depocentres, and impinging thick crustal regions of the eastern Himalayas and Shillong Plateau, have all affected the overall shape 
(wedge taper) of the modern IBR, with the wedge and retro-wedge behaving anomalously compared with typical accretionary prisms. All tectonic models proposed for the IBR/WBT have weaknesses or ambiguities, and there is considerable scope for future research to resolve the many outstanding, tectonic, metamorphic, structural, and sedimentary issues. These are important tasks because the IBR is a key region for understanding the development of northern Gondwana, the Himalayan orogeny, and SE Asia, as well as providing insights into the complex development of highly oblique collisional margins.

\section{Introduction}

The Indo-Burma Ranges (IBR), and the adjacent Central Basin and Wuntho-Popa Arc, represent a Mesozoic accretionary-forearc basin-arc complex (referred to here as the West Burma Terrane) related to subduction of various stages of the Tethys ocean, analogous to the Makran accretionary complex some $3000 \mathrm{~km}$ to the west (see reviews in Rangin et al., 2013; Rangin, 2017; Burg, 2018). Parts of both complexes are affected by transpressional Cenozoic post-accretionary phase tectonics at the eastern and western margins of the India Plate. As India converged with Eurasia, accretionary prism complexes contiguous with the Makran and Indo-Burma Ranges became incorporated into the Himalayan Orogen. The resulting the Indus-Yarlung Suture Zone (IYSZ), comprises 177-150 Ma and 130-80 Ma ophiolites (Hebert et al., 2012), serpentinite and sedimentary matrix mélanges, and trench and wedge top basins (Ding et al., 2005; DeCelles et al., 2014; Li et al., 2015). The mountain belts of the Kirthar, Brahui and Sulaiman ranges in Pakistan lie oblique (N-S to NE-SW) to the E-W Makran and Himalayan trends, on the west side of the India Plate. These ranges are equivalent to the NW-SE to N-S trending Indo-Burma Ranges on the east side, in accommodating the lateral motion of India moving northwards relative to Eurasia. SE Asia 
48 (Sundaland) and the Afghan Block/Central Iran areas of Eurasia formed southerly continental

49 protrusions on the eastern and western flanks of the Indian Continent respectively (e.g. Rangin et al., 2013; Burg, 2018). In the oblique position on the eastern margin, the West Burma Terrane linked with India as it moved northwards, and underwent considerable strikeslip translation (Rangin et al., 2013; Rangin, 2017, 2018). However, the details of how deformation evolved within the Indo-Burma Ranges, how much dextral translation has affected the region, and the tectonic context and timing of emplacement of the fragments of oceanic crust all remain controversial. Like the Makran (Burg, 2018) and IYSZ (e.g. Hebert et al., 2012), the Indo-Burma Ranges contain a very important record of the Tethys subduction history that can be used to test and refine Mesozoic-Cenozoic plate reconstructions. The Eocene sedimentary record of the forearc in the Central Basin is very significant for understanding the palaeoclimate history of the region, including development of the monsoon (e.g. Licht et al., 2018). For both tectonic reconstructions and palaeoclimate history a much better understanding of the development of the IBR and West Burma Terrane is needed.

Fundamental challenges to understanding the IBR include: historically highly limited access by roads and trails; limited exposures in high relief terrain covered by jungle; highly complex structure; very extensive, highly monotonous flysch units with a wide age-range (Triassic-Palaeogene) and limited biostratigraphic control (e.g. Brunnschweiler (1966), Bannert et al. (2011); and access to areas restricted by political unrest. While these issues still exist, progress with accessibility to some areas has occurred. Road building has created some new outcrop sections, and some excellent river sections exist. U-Pb dating of zircons and other dating methods have advanced our understanding of the timing of tectonic, igneous, and metamorphic events and stratigraphy (Table 1, see review in Zhang, J. et al., 2018 and Licht 
et al., 2018). Geochemical analysis of 'ophiolites' has better identified their tectonic setting

73

74

75

76

77

(Table 1).

The geological context of tectonic events in the IBR remain open to multiple interpretations. In this paper, we review the evidence for key structural relationships, and timing of events, and additionally provide new structural observations that we have made from fieldwork over two field seasons in the Kanpetlet-Mindat area, and the Kaylemyo area. We have also added analysis of satellite and Google Earth data. The aim is to provide an updated overview of the structural development of the core and Inner Belt of the IBR. While we cannot resolve all the questions that we pose, a review of all the data is important at this time in order understand what the data presently suggests, and to focus new research to address key gaps or uncertainties in our understanding. Key basic questions, for which there are a diversity of unresolved opinions in the literature, include: how the structural styles evolved with time, the timing of ophiolite emplacement, how the ophiolites in Myanmar relate to those in the Naga-Manipur region of India, how the events in the IBR relate to plate tectonic models of the region, and how the accretionary prism was modified by oblique collision.

\section{Geological Background}

The IBR (Fig. 1) comprise a thick sequence of Mesozoic and Cenozoic flysch deposits associated with several large and numerous small 'ophiolite' fragments. The ranges initially formed in an accretionary prism setting, then evolved to a sub-aerial fold-and-thrust belt during highly oblique collision between Sundaland and the India Plate, their general characteristics have been described in a number of publications (e.g. Brunnschweiler, 1966, 1974; Maurin and Rangin, 2009; Bannert et al., 2011; Mitchell, 1993, 2017; Mitchell et al., 
2010; Rangin et al., 2013; Rangin, 2017; 2018). The ranges are also known from the adjacent areas of Bangladesh (e.g. Gani and Alam, 1999; Steckler et al., 2016b) and India (e.g. Ghose and Singh, 1981; Singh and Ghose, 1982; Ghose et al., 2014; Fig. 1). Traditionally the IBR has been divided into an outer Western Belt, and an inner Eastern Belt (e.g. United Nations, 1979; Mitchell et al., 2010). The identification of this division is not facile everywhere in the ranges, and is clearest in the Chin Hills, where the Kheng Fault (Fig. 1) divides the two belts. Maurin and Rangin (2009) use Outer Belt for the detached fold and thrust system developed primarily in Neogene sediments, Inner Belt for the folded and thrusted region of predominantly Late Cretaceous-Palaeogene section, and Core for the most easterly and tectonically complex zone (Fig. 1). The Core marks a broad suture zone of Tethys ocean and related back-arc basin-derived rock units comprising oceanic crust-related units (including large and small bodies of peridotite and serpentinite, pillow lavas, radiolarian chert, mélange), a poorly dated flysch unit that appears to be primarily of Late Triassic age (Pane Chaung Formation), and metamorphic units that include fragments of the metamorphic sole to large ultrabasic bodies (e.g. Webula Bula area, Zhang et al., 2017). A larger region of predominantly low-grade metamorphic rocks, called the Kanpetlet Schists, crops out in the Southern Chin Hills area (Fig. 2). These schists are thought to be partly or entirely metamorphosed equivalents of the Pane Chaung Formation (United Nations, 1979a; Maurin and Rangin, 2009; Bannert et al., 2011).

The thick Mesozoic-Cenozoic flysch deposits of the IBR are typically poorly fossiliferous, and difficult to differentiate, particularly in the Inner (eastern) Belt (Brunnschweiler, 1966; Bannert et al., 2011). Since mass transport complexes of highly variable dimensions are common, reworking of older fossiliferous strata (e.g. radiolarian cherts, foraminiferal limestones) into younger deposits frequently occurs (Brunnschweiler, 
1966; United Nations, 1979a), thereby making biostratigraphic dating of these units problematic.

The Indo-Burma Ranges extend N-S for $1,300 \mathrm{~km}$, broaden northwards and are up to a maximum of $300 \mathrm{~km}$ wide passing from the Kabaw Valley in the east, to the most external folds in the west in Bangladesh (Fig. 1). The extent of the oldest part of the Indo-Burma Ranges to the east is uncertain, because of the Late Cretaceous-Recent cover of the Central Basin (forearc basin). However, the metamorphic rocks and ophiolites of the Jade Belt Region, exhumed along strike-slip faults in the $26^{\circ} \mathrm{N}$ uplift area (Fig. 1), indicate one of the following scenarios: 1) a separate suture lies about $120 \mathrm{~km}$ west of the Indo-Burma Ranges, 2) that the full IBR accretionary sequence is over $400 \mathrm{~km}$ wide, when the extent under the forearc basin is also considered (e.g. Kyi Khin et al., 2017; Mitchell, 2017), or 3) that the Jade belt is the offset equivalent of the Kalymo ophiolites (e.g. Morley, 2017; Ridd et al., 2019).

The United Nations (1979a) study, which comprises three 6-7 month long field seasons (1975-1978) with 8-10 geologists in the field parties, is by far the largest effort to date to understand the geology of the Myanmar Indo-Burma Ranges. This program provided the geological maps still used today for key areas (Falam-Kalemyo area, northern Chin Hills; Mindat-Saw area, southern Chin Hills, and the central Arakan area; Fig. 1, 2 and 3). It and established the stratigraphic and structural framework for the Indo-Burma Ranges and conducted widespread stream sampling for mineral exploration.

More recent studies of the Indo-Burma Ranges used 2D seismic reflection data to investigate the nature of the plate boundary and the southern extent of the ranges offshore (Nielsen et al., 2001; Rangin, 2018), and conducted fieldwork, which resulted in estimates of the pressure-temperature conditions of metamorphism in the Kanpetlet Schists (Socquet et 
al., 2002), and a structural model for the development of the Indo-Burma Ranges (Maurin and Rangin, 2009). This work suggested that subduction ceased early in the Cenozoic, and instead an inactive, dangling Indian Plate slab is present that is undergoing lateral dextral translation (e.g. Rangin et al., 2013, Rangin, 2017, also see Morley, 2009). Cenozoic deformation in the IBR is probably strongly strain partitioned, strike-slip motion appears to be most important in the Inner Belt, and perhaps negligible in the Outer Belt, which is dominated by convergent deformation above a detachment (e.g. Maurin and Rangin, 2009; Betka et al., 2018). While disagreement remains as to whether subduction is still ongoing (e.g. Steckler et al., 2016a; Sloan et al., 2017), or not (Rangin et al., 2013; Rangin, 2017; 2018), there is general agreement that modern motions involve about $46 \mathrm{~mm} \mathrm{yr}^{-1}$ of highly oblique motion of India with respect to Sundaland, of which about $21 \mathrm{~mm} \mathrm{yr}^{-1}$ is accommodated by the Sagaing Fault (Steckler et al., 2016a). This leaves the remainder of the motion to be accommodated by contractional and strike-slip deformation across the IndoBurma Ranges (Maurin and Rangin, 2009; Rangin et al., 2013; Stecker et al., 2016a; Rangin, $2017 ; 2018)$

\subsection{The Kalymo Suture zone}

\subsubsection{Ophiolites}

There are many conflicting models for the type of ophiolite, emplacement direction of the ophiolite, and location of the ophiolite suture zone in the Indo-Burma ranges (see review in Searle et al., 2017). Most of these models tend to envisage the ophiolite as initially being a Penrose-type obducted ophiolite, that was subsequently eroded and dismembered (e.g. United Nations, 1979a; Mitchell 1993; Socquet et al., 2002; Acharyya, 2007; Rangin, 2018).

Alternatively, the ophiolites in the IBR are interpreted as accretionary-type (Franciscan-type, e.g. Gealey, 1980; Harris, 1992, 2003), where most of the fragments of ophiolite-related units (i.e. slices of pillow lavas, deep sea sedimentary rocks, gabbros, serpentinite) are derived 
from the downgoing plate (e.g. Harlow et al., 2014; Fareeduddin and Dilek, 2015). Fragments of oceanic lithosphere including high pressure/low temperature metamorphic rocks (i.e. blueschists, jadeitite, eclogites) are interpreted as products of exhumation along a subduction channel, together with coherent blocks (peridotite, serpentinite, metamorphic sole) from the overlying forearc or supra-subduction zone oceanic lithosphere (e.g. Gealey, 1980; Harris, 1992, 2003; Harlow et al., 2014; Fareeduddin and Dilek, 2015).

Ophiolite fragments can also be generated by skinning or tectonic slicing of the downgoing slab (e.g. Li et al., 2004; Monie and Agard, 2009; Angiboust and Agard, 2010; Vogt and Gerya, 2014; Ruh et al., 2015). Slicing commonly occurs within the subduction channel, but can also occur beneath the distal part of the wedge, or slices can be inserted in the very proximal part of the wedge (Vogt and Gerya, 2014; Ruh et al., 2015). To the south of the IBR, slices of upper crust about 1-2 km thick have been observed on seismic reflection data across the Sunda Forearc and prism associated with thrusts, normal faults and duplexes around the lower plate-base accretionary prism contact (Luschen et al., 2011). Early subduction of the Jurassic part of the slab below the IBR accretionary prism could have inserted variable thickness slices of Jurassic age oceanic crust into the prism bisecting Pane Chaung Formation and Kanpetlet Schists, while later subduction inserted slices of Cretaceous age ophiolite oceanward, landward or adjacent to the Jurassic-age slices. Thus, the stacking order of units in thrust sheets cannot reliably be used to infer the relative paleogeographic position of deepwater sediments with respect to other units such as the Pane Chaung Formation and Kanpetlet Schists. This ophiolite fragmentation was further enhanced by extensive Cenozoic dextral strike-slip faulting.

The timing of ophiolite exhumation is also controversial and is based upon the appearance of ophiolitic clasts in sedimentary rocks and the timing of related unconformities (Appendix 1), while the age of emplacement is given by the age of the metamorphic sole 
(Table 1). Some ophiolite fragments were emplaced prior to the deposition of AptianCenomanian limestones (e.g. United Nations, 1979a; Mitchell et al., 1993, 2010). Erosion of ophiolites (i.e. probable subaerial emergence of parts of the accretionary prism) occurred episodically during Maastrictian times (e.g. Socquet et al., 2002; Rangin et al., 2013), to the Late Eocene-Early Oligocene for the Naga-Manipur region of India (Ghose et al., 2014). A detailed discussion of the stratigraphic evidence for the unconformities related to ophiolite emplacement is provided in Appendix 1. The diachronous timing, mixed origins (supra subduction zone, and mid oceanic ridge-type) for the oceanic crust fragments, and highly dismembered nature of the ophiolites best fits with an accretionary-type model, where the oldest ophiolites, related to Jurassic age subduction, lie to the east, and the youngest ones (Late Cretaceous-Eocene) lie to the west (Fareeduddin and Dilek, 2015; Hla Htay et al., 2017; Barber et al., 2017; Zhang et al., 2018). However, as discussed in section 4 (Tectonic evolution of the IBR), there are tectonic and paleogeographic considerations that impact which ophiolite models are appropriate for a particular time period.

A cross-section through the Indo-Burma Ranges is shown in Figure 4. It is constructed assuming the ranges developed following the accretionary-type model. Much of the structure shown is schematic, and is partly based on cross-sections in Betka et al. (2018), Maurin and Rangin, (2009) and Rangin et al. (2013). Seismic reflection data can only help constrain the geometry of the Chindwin Basin in the east, and the Neogene section of the Outer Belt and Rakhine margin in the west.

\subsubsection{Sedimentary and meta-sedimentary units of the suture zone}

The primary stratigraphic units in the suture zone are thick sequences of turbidites assigned to the Pane Chaung Formation, and underlying, generally low-grade metamorphics of the Kanpetlet Schists (United Nations, 1979a). Scattered outcrops of mélanges, deep-water 
radiolarian cherts and exotic limestones are associated with the ophiolite suite (United Nations, 1979a, Mitchell et al., 2010; Zhang, J. et al., 2017; Figs. 2 and 3). The best exposed ophiolitic mélange is found in the spillway area of the Yazagyo Dam (Fig. 5; Zhang et al., 2018), where an ultrabasic klippe overlies Triassic sandstones and mudstones (Zhang et al., 2018). The spillway reveals a melange, whose blocks include bedded red cherts (some dated as Middle Jurassic, Zhang et al., 2018), limestones and serpentinite, sheared in with basalts. $\mathrm{U}-\mathrm{Pb}$ ages of zircons from gabbros and rodingites in the mélange are Early Cretaceous, ranging between $126.2 \pm 2 \mathrm{Ma}-133.1 \pm 2 \mathrm{Ma}$ (Liu et al., 2016a; Zhang et al., 2018).

The Triassic age of the Pane Chaung Formation is based on the rare occurrence of Halobia fossils (United Nations, 1979; Bannert et al., 2011; Yao et al., 2017; Zhang et al., 2017; see review in Mitchell, 2017). However, across large tracts of the Indo-Burma Ranges the Pane Chuang Formation has been identified based on lithological characteristics, without supporting fossil evidence. The discontinuous nature of outcrops in the IBR, and lithological similarities with overlying Cretaceous units, cause considerable uncertainty in mapping the Pane Chaung Formation (Brunnschweiler, 1966; Bannert et al., 2011; Brunnschweiler (1966). Detrital zircon analysis of the Pane Chaung Formation, helps address the problem of correlation, and samples from the Magway, Mindat, Saw River, Kanpetlet and Kalemyo areas indicate the maximum depositional ages are predominantly of Late Triassic age, together with some Early Jurassic ages (Sevastjanova et al. 2015 and Yao et al., 2017).

Along the Kalemyo-Falam and the Webula-Taung-Falam road sections the Pane Chaung Formation is apparently unconformably overlain by Upper Cretaceous flysch (Campanian, Maastrichtian, Falam Formation, Mitchell et al., 2010). Is the depositional gap between the Early Jurassic and Upper Cretaceous real, and if so what is the explanation? There are simply too few occurrences of fossils in the sequences to be sure of the full age range of the Pane Chaung Formation. Additionally, if the only source of Mesozoic zircons is 
related to Triassic-Early Jurassic tectonic events, then detrital zircon evidence will not be able to establish whether there is a component of Late Jurassic or Early Cretaceous section in the Pane Chaung Formation. This is a known problem concerning detrital zircon data derived from Sibumasu (Cai et al., 2016). We will leave the issue of the age range of the Pane Chaung Formation as being posed, but without any firm conclusion.

\section{Structural Field observations of the Suture zone and Inner Belt}

\subsection{Thrusts at base of ultrabasic bodies}

Most of the structural contacts in the Naga-Manipur region are described as thrusts, often high angle (typically around $45-60^{\circ}$ ), and commonly imbricates (Ghose et al., 2010, 2014). Brunnscheweiler (1966) notes one locality where the western margin of the Webula Bula peridotite is thrust over the Pane Chaung Formation (Fig. 3). However, Bannert et al. (2011) tend to show high angle, strike-slip fault related contacts bounding the ophiolites, based on field observations and satellite image interpretation.

In the Kalemyo area we investigated five peridotite bodies, but only Webula BulaKhwekha, Bhopi Vun and Yazagyo Dam provided good outcrops where it was possible to get close to major lithological boundaries (Fig. 5A; 6). The peridotites form large hills, and are predominantly composed of extensively fractured and serpentinized harzburgites, some lherzolites, dunites and gabbros are also present. There is some associated chromite-nickel mining, particularly around Mwe Taung. It is difficult to find clear outcrop contacts between lithologies, but by using mapped contacts, and their intersection with topographic contours it is possible to determine the general dips of the contacts (Fig. 7). The base of the Webula Bula ophiolite is a gently dipping thrust averaging $10^{\circ} \mathrm{E}$ dip (Fig.7). The presence of a low-grade metamorphic mélange unit overlain by a greenschist to amphibolite grade metamorphic sole below the southern outcrops of the Webula Bula ophiolite (Khwekha; Fig. 6) also supports 
the low-angle thrust interpretation (Fig. 3; Zhang et al., 2017, 2018). The average dip of the base of the ophiolite at Bhopi Vun is $14^{\circ} \mathrm{E}$, and $34^{\circ} \mathrm{E}$ at Mwe Taung (Fig. 7). We conclude that ophiolite fragments were initially emplaced along thrusts, but in many places were subsequently affected by strike-slip deformation.

\subsection{Structure of the Kanpetlet Schist}

The Kanpetlet Schists are a monotonous, thick sequence of highly deformed quartzmica schists (Figs. 8 and 9), that in places are black and graphitic. Thick to thin bands of metabasites (greenstones) are scattered through the unit. Metabasites within the schist exhibit actinolite-chlorite associations (greenschist facies), while metapelites show chlorite-phengite associations, characteristic of greenschist conditions around $4-5 \pm 1 \mathrm{~kb}, 300-400 \pm 100{ }^{\circ} \mathrm{C}$ (Socquet et al., 2002). In some metagreywackes, boarderline greenschist and blueschist metamorphism, from chlorite-riebeckite-crossite-epidote-albite associations, indicates conditions around $8 \pm 1 \mathrm{~kb}, 450 \pm 100^{\circ} \mathrm{C}$ or depths of $\sim 25 \mathrm{~km}$ (Socquet et al., 2002).

According to Socquet et al. (2002) the Kanpetlet Schists have been considerably extended, and this deformation is associated with a strong $\mathrm{N} 120^{\circ}$ mineral lineation, with ductile shearing towards the SE. However, there are no maps that show the extent to which this extensional deformation can be identified in the Southern Chin Hills. An example of top to the SE shear in the schists is shown in Fig. 8D. Maurin and Rangin (2009), described the presence of $\mathrm{N} 165^{\circ}$ mullions in the Mindat Anticline, where shear criteria in quartz exolutions (see Fig. 9a for an example) show a top to the north deformation as a result of deep northward transport, on complex sheath fold type structures, related to right lateral shear. There is no detailed structural information presented to support the model. Zhang et al. (2017) studied the main road to Mindat section across the Mindat Dome. They note the presence of multiple deformation phases, and suggest an early N-S striking foliation, with 
cleavages of second generation folds striking NE-SW, and third generation folds striking

NW-SE. The timing of metamorphism has not been established by radiometric dating, however, exotic blocks of Kanpetlet Schist occur within the Sin Chaung succession, indicating a pre-Campanian age, furthermore the schists probably pre-date the Paung Chaung Limestones that overlie them, which suggests an Albian or older age for the metamorphism (United Nations, 1979; also see Appendix 1).

We observed the Kanpetlet Schists along the Saw River, the Saw to Mount Victoria Road, the main Midat road, and the Mindat-Kanpetlet road. The schists tend to either exhibit low-angle foliations where crenulations (Fig. 9c) and small-scale folds have gently plunging hinges, and steep axial surfaces, or high angle foliations, with small-scale folds that have gently plunging hinges and sub-horizontal axial surfaces (Fig. 8). The fold hinges on the lowangle foliations commonly trend $110^{\circ}-140^{\circ}$ and are inclined from $0^{\circ}$ to $45^{\circ}$. The transition between these two orientations is observed in some outcrops (Fig. 8A,C), and can be interpreted in the context of sheath folds (Fig. 8) related to NW-SE dextral shearing, as suggested by Maurin and Rangin (2009). The extensive presence of folds with sub-horizontal axial surfaces could also accommodate considerable vertical flattening. In our measurements of fold hinge orientation in addition to NW-SE trends, there are also diverse E-W and N-S to NE-SW orientations. Foliation strike is highly varied and includes E-W, NNW-SSE, NNESSW and N-S trends (Fig. 10). In a number of outcrops, often in strongly weathered schist, we observed late, NNW-SSE to NNE-SSW trending sub-vertical, brittle fault zones, which are related to the latest phase of dextral deformation, after exhumation of the Kanpetlet schists in the Mindat Dome.

At the largest scale in the Southern Chin Hills the Kanpetlet Schists form a domal feature called the Mindat Anticline or Dome (Fig. 2). Zhang et al. (2017) interpret the anticline as an extruded wedge associated with exhumation of high pressure, low temperature 
metamorphics. This interpretation requires the overlying Pane Chaung to exhibit an extensional detachment with the Kanpetlet Schist, that is yet to be convincingly demonstrated in outcrop. Additionally, the anticline appears to be a late structure related to the Kheng Fault, which emplaces the Inner Belt against Palaeogene section (Fig. 2), and is not related to an earlier (Mesozoic) wedge extrusion. The blueschists and eclogites from the Naga Hills, cited by Zhang et al. (2017) as examples of metamorphism in the core of the anticline, are over $300 \mathrm{~km}$ away, on completely different structures. Consequently, the wedge extrusion model is highly conjectural.

While some interesting structural and metamorphic features within the Kanpetlet Schists have been identified in previous studies, the level of detail provided is low. For example, there are indications that thinning of the schists has occurred, but the timing, kinematics, and tectonic significance of the thinning has yet to be determined (e.g. is it wedge extrusion, extensional collapse of thickened crust, or extension associated with dextral shear, or multiple events). How local observations of a particular shear direction or fold can be traced more regionally is unknown. It is apparent that numerous events related to deformation within an accretionary prism, and in the later strike-slip affected orogenic wedge are present in the Kanpetlet Schists. To properly unravel these events requires a much more integrated and detailed study of the metamorphism, geochronology and structural development than is available from present studies

\section{3.. Structure of the Pane Chaung Formation}

Mitchell et al. (2010) describe the Pane Chaung Formation as having a complex structure, with widespread 'broken beds'. Within and overlying the flysch are partially serpentinised bodies of harzburgite, dunite, gabbro and chromitite. The United Nations study 
provides excellent information on the large-scale structure, but details about the structure of the Pane Chaung Formation are lacking. Recent road improvement schemes have enabled a few continuous sections to be observed through the Pane Chaung Formation on the roads to Kanpetlet, Mindat, and Falam (Zhang et al., 2017; Yao et al., 2017). Here we focus on the road section to Mindat, which offers the best exposed sections through the Pane Chaung Formation.

The E-W Kyaukhtu- Mindat road section traverses about $2 \mathrm{~km}$ width of the Pane Chaung Formation on the east side of the Mindat Dome (Fig. 2), and provides numerous sections, with the best ones being in excess of $100 \mathrm{~m}$ long of continuous exposure. The exposures tend to show steep to vertical beds, affected by isoclinal folds, with sub-vertical axial surfaces (e.g. Fig. 11A). Similarly, flat lying dips can be associated with isoclinal recumbent folds (Fig. 11B). These two fold styles are commonly juxtaposed or superimposed. Bedding strike directions and the strike of fold axial surfaces predominantly range from NW-SE to NE-SW, with NNE-SSW and NNW-SSE directions being particularly favoured (Fig. 11B). In the Southern Chin Hills the dip of fold hinges varies considerably from about $60^{\circ}$ to horizontal. Thrust faults strike predominantly NNE-SSW, although two have NW-SE strikes. Sub-vertical, often upwards splaying, dextral strike-slip faults are common features that strike between NNW-SSE and NNE-SSW directions, with N-S being the most frequent.

In some parts of the sections bedding can be traced consistently across the outcrop. But often bedding is highly discontinuous or competent units are simply blocks in a finegrained matrix (block-in-matrix). In such areas it is easy to understand why these are described as broken beds (United Nations, 1979; Mitchell et al., 2010). In many cases broken beds are syn-sedimentary mass transport units, but later deformation has further enhanced the disruption of bedding, both within the mass transport deposits, and within the initially more 
continuous turbidite sandstone-shale units. Tectonic folds are characterised by fracturing, veins, sometimes cleavage development and related brittle faults, while syn-sedimentary structures exhibit more ductile style folds with stretched limbs, and discontinuous beds in a shale matrix.

In the Saw River section normal faults that strike between $100^{\circ}$ and $145^{\circ}$ are exposed (Figs. 12 and 13). Competent and incompetent beds have been dragged into some fault zones, with a deformation style typical of poorly lithified beds (Fig. 12A, C). Two fault zones show early normal sense of drag in the footwall, but exhibit an unusual normal fault geometry where bedding in the hangingwall lies sub-parallel to the fault plane (Fig. 12A,C). Typically normal faults cut bedding at a high angle in the hangingwall, unless the fault flattens into a bed-parallel detachment. While inversion can move the hangingwall flat geometry upwards, onto the high-angle part of the fault (e.g. Fig. 12A). The presence of inversion is supported in Fig. $12 \mathrm{C}$ by the presence of a small thrust fault in the normal fault hangingwall. In Figure 13 a small thrust with a ramp-flat geometry truncates two small earlier normal faults. We interpret the inversion structures, and deformation style of the fault zones to indicate the normal faults formed early (perhaps gravity driven, or related to crustal extension), prior to compressional deformation.

The presence of overturned beds, in some places consistently overturned for several kilometres, has been noted during mapping by the United Nations (1979a) program. In the Southern Chin hills area, minor folds with antiformal syncline and synformal anticline geometries and younging directions consistent with a structural position on the inverted limb of a major nappe structure have been described (United Nations, 1979a). From the Mindat Road section (Fig. 10B) we see relatively small-scale recumbent, isoclinal folds, that are possibly related to this phase of deformation. These structures formed relatively early (F1) since they are deformed and folded by later structures. For example, in Fig. 14 the F1 folds 
have been folded by later upright folds (F2) that are cut by later NNW-SSE striking, WSWdirected thrusts (T1). These thrusts truncate earlier small-scale folds. In Figure 15 a fold (F4) with a steeply-dipping axial surface that is associated with an oblique-reverse dextral strikeslip fault set (SS1) folds the sub-horizontal F1 axial surface. At the eastern end of the outcrop in Fig. 16B, an early set of thrusts (T1) is present, with thrust $\mathrm{X}$ being truncated up dip at point $\mathrm{Y}$ by a top to the ESE thrust, and down dip at point $\mathrm{Z}$ by a zone of steeply dipping strike-slip faults (SS1). Some small, fault-related folds (F3) are related to the T1 thrusts.

The road sections indicate early recumbent folding is affected by a later phase of dominantly WSW-verging, to upright folding, accompanied by predominantly ENE-dipping, WSW-directed thrust faults. Later oblique-reverse dextral strike-slip motion (predominantly on NNE-SSW faults, but ranging between NW-SE and NE-SW orientations) extensively affected the sequence, and produced dominantly upright to ESE-verging folds, together with some thrusts and late normal faults. The sequence of events affecting the Pane Chaung Formation is summarised in Figure 17.

The road from Kalemyo to Falam also passes through extensive outcrops of the Pane Chaung Formation (Yao et al., 2017). Sections through the formation in the Kalemyo area show generally steeply dipping, commonly tightly to isoclinally folded beds, that are cut by steep, sub-vertical strike-slip faults that strike between $340^{\circ}$ and $015^{\circ}$ (Figs. 18 and 19). The orientation of bedding is not as diverse as in the Chin Hills area (Fig. 18), and ranges between NNW-SSE and NNE-SSW directions, with the NNW-SSE trend being most frequent.

Unfortunately, a constant theme of the Mesozoic-Cenozoic stratigraphy of the IndoBurma Ranges is the absence of simple, clear, mappable units (Brunnschweiler 1966; Bannert et al., 2011). The major units, typically $1000+\mathrm{m}$ thick, can be identified, but the absence of distinctive marker units or fossils hampers identification of structures at the meso-scale, 
limiting structure identification to the outcrop and regional map scale, but not in between.

Viewing the best new road sections we can see extensive arrays of folds and faults with fold wavelengths of metres to tens of metres, in a section 10-15 m high (Figs. 14-17). Yet the height from the valley floor to the road is in the range of 400-600 $\mathrm{m}$, and these small strips of exposure, by necessity, have to be treated as representative of the larger-scale structure.

\subsection{Kalemyo-Kennedy Peak area}

We observed the Pane Chaung, Late Cretaceous (Falam Formation) and Palaeogene flysch (including the Kennedy Peak Sandstone) in the Kalemyo area, and in particular along the Kalemyo-Falam road, where there are extensive good exposures (Fig. 20). Gradual changes in sedimentary characteristics through the section are evident, with no sharp boundary between units. We relied on the mapped boundaries (United Nations, 1978; Mitchell et al., 2010) to indicate approximately where changes in formation were to be expected. The clearest example of the boundary between the Pane Chaung and the Falam Formation we found is on the Webula Bula-Falam road. In low lying outcrops the Pane Chaung is affected by short wavelength folds, and exhibits numerous quartz veins, and overall bedding exhibits NNW-SSE strikes and eastwards dips. Sandstone beds are commonly discontinuous. About $30 \mathrm{~m}$ of landslide-affected hillside separates the Pane Chaung from the Falam Formation. The Falam Formation exhibits more continuous sandstone layers and a few small limestone clasts or floaters, quartz veins are largely absent. Bedding is steep, but continuous, with no short wavelength folds. The presence of limestones is typical of the Falam Formation, which contains olistoliths of pelagic limestones that can be up to several kilometres long (Fig. 20A,B). Bedding strike ranges between $320^{\circ}$ and $340^{\circ}$ with dips consistently around $65^{\circ}$. The geological map shows the contact between the two formations as a thrust. However, the outcrop geometry, suggests that the Pane Chaung Formation simply dips below the Falam Formation, and the contact is an east-dipping 
unconformity, a rotated thrust contact is, however, a possibility. In other stream cuts, and on the Kalemyo-Falam road we observed similar relationships in the vicinity of the mapped contact, suggesting an unconformable contact rather than a structural contact.

Figure 18 shows a cross-section from the Kennedy Peak region to the Kalemyo, constructed from measurements taken along the Kalemyo-Falam road, and Falam-Kennedy Peak road. In the east the Bhopi Vun ultrabasic body overthrusts (Fig. 7B) the Triassic section. The Triassic is tightly folded, and affected by sub-vertical, approximately N-S trending, strike-slip faults (see Section 3.2). These are relatively late structures, and overprint early folds and thrusts. The earlier structures tend to strike NNW-SSE. The reason why the Pane Chaung Formation is exposed in the core region could be due to uplift in a transpressional zone, with major faults marked $\mathrm{Z}$ schematically represented in Figure 18. The Falam Formation is internally deformed by numerous, short wavelength minor folds, that tend to be upright to west-verging, together with some secondary thrust faults. Passing upsection to the west the deformation becomes less intense and passes into the Paleogene Chunsung Formation. Although the Kennedy Sandstone is mapped as overlying the Chunsung Formation, both are deepwater turbidite units, and we suspect that the Kennedy Sandstone is a more sand-rich lateral equivalent unit to the upper part of the Chunsung Formation. This enables a simple synclinal geometry to be drawn that matches the data we gathered on our traverse. There appears to be some stratigraphic thickening passing across the syncline from east to west.

The Falam and Pane Chaung Formations both show bedding that strikes predominantly NNW-SSE with high dip angles (Fig. 18), and the outcrops display numerous examples of short wavelength folding. There is a contrast with the Palaeogene section, which shows gentler dips, and NNE-SSW strike directions on west-dipping bedding and much less 
short-wavelength, outcrop-scale folding. The main syncline is a broad simple fold, with a wavelength of around $6 \mathrm{~km}$.

Between the Saw and Kalemyo areas the topography of the Inner Belt and Core decreases, and in this region some larger-scale structures can be identified on satellite data, which indicates what the map-view geometry of structures in other, less well imaged areas might be like (Fig.21). The images show that major folds can be picked out within the Chunsung Formation, these folds exhibit axial surfaces with a range of orientations between NW-SE and NNE-SSW, and wavelengths of around 2-4 km. The folds have a very similar size and appearance to the Makran accretionary prism (Fig. 21). A linear, fault-controlled ridge separates the Chunsung Formation from the Falam Formation in Figure 21. This fault is probably related to the Kheng Fault to the south.

\subsection{Kabaw Fault}

The Kabaw Fault (Fig. 1 and 23) was originally interpreted as an east-dipping fault that approximately marks the abrupt boundary between the Central Basin to the east, and the Indo-Burma Ranges and extends almost the full length of the ranges (Win Swe et al. 1972). Later east-dipping interpretations have been made by Wang, Y. et al. (2014) and Stecker et al. (2016a). The fault zone has been interpreted as a west-dipping fault by Hla Maung, (1987) and Curray, (2005).

Maurin and Rangin (2009) show the core region of the Indo-Burma Ranges is thrust eastwards over the Central Basin along the reverse-dextral slip, west-dipping Kabaw Fault. The Kabaw Fault in this type of section can be viewed as a back-stop to the accretionary wedge. In map view Maurin and Rangin (2009) interpret the arcuate Kabaw fault as extending almost the entire length of the Indo-Burma range, and in the south passing into a 
dextral strike-slip fault. Wang, Y. et al. (2014) follow the same type of backstop wedge model as Maurin and Rangin (2009), but only for the southern Indo-Burma Ranges and Andaman Sea.

The potential for the Kabaw Fault to form a major fault zone along the eastern boundary of the Indo-Burma Ranges has led to concerns regarding its potential seismic hazard (e.g. Wang, Y. et al., 2014). However, GPS data lacks a significant drop in displacement passing across the Kabaw Fault, unlike the Sagaing and Churachandpur-Mao faults (e.g. Stecker et al., 2016a). According to Steckler et al. (2016a) the drop in fold beltparallel displacement rate across the Sagaing Fault is about $20 \mathrm{~mm} / \mathrm{yr}^{-1}$, and about $10 \mathrm{~mm} / \mathrm{yr}^{-1}$ for the Churachandpur-Mao Fault. For the intervening region between these two faults, including the Kabaw Fault, the decrease of around $6 \mathrm{~mm} / \mathrm{yr}^{-1}$ is more diffuse (Stecker et al., 2016). Possibly the Kabaw Fault was a more active feature in the past, and strike-slip activity has migrated westwards with time. Other GPS studies of the Churachandpur Mao Fault measured a 17-20 mm/yr change in velocity (from 16-22 mm/yr on the western side, to 33-42 mm/yr on western side; Kumar et al., 2011; Kundu and Gahalaut, 2013), leaving even less margin for displacement on the Kabaw Fault.

The west-dipping interpretation for the Kabaw Fault is structurally the simplest one, as this places older, more highly deformed, higher metamorphic grade rocks (including ophiolites) in the hangingwall over, younger, sedimentary rocks in the footwall. The eastdipping thrust fault would be the inverse case (younger rocks over older), is more problematic for a thrust, and implies either an out-of sequence thrust interpretation, or the fault is a normal fault or predominantly a strike-slip fault.

The Kabaw Fault lies at the boundary between the Indo-Burma Range units and the Central Basin units (Bannert et al., 2011). Most critically in the Saw sector of the Chin Hills 
the boundary between these units is marked by a series of unconformities (base of the Paung

512 Chaung Formation, base of the Kabaw Formation, see Appendix 1). Field relationships

513

514 (United Nations, 1979), and satellite images (Fig. 22) indicate that in the Mindat-Kanpetlet sector the boundary between the Paung Chaung Formation or the Kabaw Formation and the Pane Chaung Formation is low-angled and east-dipping. This would fit either an east-dipping unconformity, or an east-dipping thrust interpretation, not a steeply west-dipping fault. This contact is described as an unconformity in the United Nations (1979) report (see Appendix 1, section 1.2 Chin Hills), which seems entirely reasonable. In this area we found no convincing evidence for a major active fault zone.

South of the unconformity in the Saw area, in the southern part of the southern Chin Hills region, a major fault zone can be identified where the contact between the Kabaw Formation and Pane Chaung Formation is linear, with no Paung Chaung Formation being mapped in the area (Fig. 23). The Pane Chaung Formation is upthrown on the western side of the fault. This follows the type of back-stop model for the Kabaw Fault shown in Rangin et al. (2013). The fault zone extends to the Bi-Taung area, west of Mindon (Fig. 23), where Bannert et al. (2011) show a cross-section through several steeply dipping to vertical strands of the fault zone (Kabaw Valley Fault) that juxtapose Kanpetlet Schist with serpentinite, and Paunggyi Conglomerate and Laungshe Formation with serpentitine. Passing northwards into the Saw region (Fig. 23) the contact between the Central Basin units and the Eastern Belt becomes less linear and more sinuous, and it is in this region that the unconformities discussed above are present (Figs. 2, Appendix 1). Hence, map and satellite analysis indicates that a major transpressional fault dies out south of Laungshe (Fig. 23). We suggest that this major fault zone be referred to as the South Kabaw Fault Zone.

The unconformity zone around Saw is characterised by hilly topography (Fig. 22B), which changes north of the latitude of Mindat, to the flat topography of the Kabaw Valley 
(Fig. 22A). The young alluvial fill of the valley masks any potential fault zone that might separate the Eastern Belt from the Central Basin, for example Bannert et al. (2011) show the Kabaw Fault only as a dashed line along the valley. One hint that an inactive strike-slip fault zone might be present is the en-echelon arrangement of the peridotite bodies on the western side of the valley (Fig. 22A). Further north, in the Naga Hills the presence of strike-slip fault zones, including the Kabaw Fault between Central Basin deposits and the Eastern Belt has been described by Bannert et al. (2011), and looks plausible on satellite images.

We found that many late strike-slip faults cut through the Pane Chaung Formation and Kanpetlet Schists (Section 2.2), indicating significant strike-slip motion within the Eastern Belt. But this dextral motion appears to be widespread within the Eastern Belt (Maurin and Rangin, 2009), rather than focussed on a particular fault zone. The topography-fault surface relationships of the Kheng Fault, which defines the western margin of the inner belt (Figs. 1 and 2), indicates a near-vertical fault zone of post-Chunsung Formation age. A linear fault, visible on satellite images also marks the boundary between the Falam Formation and the Chunsung Formation in the Falam-Mindat sector (Fig. 21). We view the Eastern Belt as being composed of many large to small displacement fault strands, with numerous faults contributing to a back-stop geometry for the wedge, rather than a single Kabaw Fault. We favour a predominantly vertical to west-dipping geometry for the key faults rather than a gentle east-dipping geometry, although some secondary east-dipping faults exist as well. There are some segments where major, transpressional fault zones can be identified (e.g. South Kabaw Fault, Kheng Fault, North Kabaw-East Naga-West Naga Fault system; Fig. 1), but these do not appear to be fully connected to form a regional 'Kabaw' Fault.

\subsection{The Indo-Burma Ranges as a critical taper wedge}



in the context of a critical taper wedge. The surface slope, and basal detachment dips define the gross thrust belt wedge geometry, whose shape is controlled by the interplay between basal detachment and wedge strength, and pore fluid pressure (Davis et al., 1983; Dahlen, 1984, 1990; Dahlen et al., 1984). When a wedge reaches critical taper it can propagate towards the foreland, at sub-critical taper it will deform internally without foreland propagation (e.g. Davis et al., 1983; Dahlen, et al., 1984), leading to synchronous and out-ofsequence thrusting (Morley, 1988). Both sedimentation and erosion modify the surface slope angle, and exert an influence on whether a wedge can attain critical taper (e.g. Storti and McClay, 1995; Morley, 2007; Simpson, 2010). overpressured, bed-parallel detachment in Neogene or Oligocene shales at variable depths between about 3 and 6 km depth (Maurin and Rangin, 2009; Bekta 2018). Further eastwards the basal detachment cuts deeper into the stratigraphy to involve Palaeogene, Late

573 Cretaceous, and Triassic units (Fig. 2; Maurin and Rangin, 2009), however, the dip angle of the basal thrust below the Eastern Outer Belt and Inner Belt is poorly constrained. Passing NS along the IBR the topography is asymmetric with the SE or E side of the ranges exhibiting a steeper average surface slope, than the wider western slope, as would be expected for the retro-wedge and pro-wedge of an accretionary prism (Fig. 24; Maurin and Rangin, 2009). out into the foreland basin of the Himalayas. The pro-wedge is relatively narrow $(<100 \mathrm{~km})$ and can be fitted well to a single average slope. In the NE region where the IBR impinges on the Himalayas the surface slope decreases considerably (Fig. 24 profile A) from $2.3^{\circ}$ to $0.6^{\circ}$. 
Indo-Burma Ranges, and is accompanied by a decrease in both the pro-wedge and retrowedge slope angle, compared with adjacent regions.

$$
\text { South of the Shillong Hills the pro-wedge morphology changes considerably }
$$

compared with Figure 24 profiles A, B, C. The impressively thick (up to $25 \mathrm{~km}$ ) Cenozoic sediment depocentre of the Bengal Trough lies on the west side of the IBR (Fig. 24), and this is where the Western Outer Belt detachment is present. The very low $0.2^{\circ}-0.4^{\circ}$ surface slope (Fig. 24 profiles E-K) implies a super-weak detachment, probably due to near lithostatic overpressures (see discussions in Suppe, 2007; King and Morley, 2017; Morley et al., 2018). For the Eastern Outer Belt the average surface slope angle ranges between $0.7^{\circ}$ and $2.3^{\circ}$. The critical taper of the belt is higher due to the increase in dips of both the surface slope and the basal detachment $\left(3.4^{\circ}-5^{\circ}\right)$, which ramps down eastwards from about $6 \mathrm{~km}$ to $12-15 \mathrm{~km}$ depth (i.e. Maurin and Rangin, 2009). The considerable change in wedge taper between the Western Outer Belt $\left(<2^{\circ}\right)$, and the Eastern Outer belt (estimated around $\left.4-7^{\circ}\right)$ probably reflects the presence of older, stronger units within the wedge, and the basal detachment lying in older, stronger rocks. The basal detachment is probably overpressured, but is stronger than the shallow detachment levels due to episodic loss of fluid during seismic activity, and the heterogeneous nature of the units forming the shear zone (e.g. Saffer and Bekins, 2002; Screaton et al., 2009; Saffer and Tobin, 2011; Tesei et al., 2015).

The width of the high (western dipping) surface slope zone varies considerably, from about $125 \mathrm{~km}$ to $20 \mathrm{~km}$. On profile $\mathrm{E}$ (Fig. 24) the zone is narrow due to the presence of the Imphal Basin, a pull-apart type basin formed along the Churachandpur-Mao Fault (e.g. Ibotombi and Singh, 2007). In this region strike-slip faulting has dramatically reduced the critical taper of the wedge. 

which marks the region of broadest, thickest Cenozoic sediment deposition in the belt. The retro-wedge is well developed here, with a high east-dipping average surface slope value of $3.2^{\circ}$. Typically, in analogue experiments the pro-wedge exhibits slopes that correspond with the minimum critical taper, while retro-wedges exhibit intermediate slopes between the minimum and maximum critical taper values, or the angle of a stable non-critical wedge (e.g. Wang and Davis, 1996; Storti et al., 2000). In a pure convergent system pro-wedges grow by frontal and basal accretion, whereas retro-wedges grow by thrusting of the pro-wedge up the retroshear zone (Willet et al., 1993). ways related to the evolution and the highly oblique convergent nature of the belt. First, the accretion of large sediment volumes to the belt, particularly during the Late Cretaceous and Cenozoic, together with the effects of the Himalayan Orogeny, has resulted in westwards migration of the active belt of deformation, with the eastern part of the wedge buried beneath the forearc basin. Consequently, unlike the analogue models where the retro-wedge remains in a fixed position (e.g. Storti et al., 2000; see review in Graveleau et al., 2012), the active retro-wedge in the Indo-Burma Ranges is located considerably to the west of the eastern margin of the Mesozoic accretionary prism (e.g. Ki Khin et al., 2017; Zhang et al., 2018). Hence, late retro-wedge vergent structures are superimposed on pro-wedge vergent structures

625 (as described in section 3.2.). Strain partitioning in the belt enables the Western Outer Belt to be purely convergent in nature according to Betka et al. (2018), while the strike-slip component of the plate convergence is concentrated in the eastern part of the IBR. As we observe in the Kalemyo and Kanpetlet-Mindat areas, late transpressional overprinting of the retro-wedge area is the dominant structural style (Section 4). 

the Pane Chaung Formation. But in the next profile to the south (G, Fig. 24) a similar value retro-wedge slope $\left(3.4^{\circ}\right)$, occurs where Palaeogene section is exposed at the surface, and the the older units to the east (Cretaceous-Triassic) are associated with a much lower slope profile $\left(0.6^{\circ}\right)$, suggesting that the active fault distribution has changed considerably between the profiles F and G. This changing pattern continues to the south, where in the Mount of the profile. The retro-wedge slope averages $2.1^{\circ}$, lower than to the north, which may reflect the importance of the Kheng Fault on the uplift of the belt, which lies west of Mount Victoria, rather than faults on the eastern side of the belt.

\subsection{Cenozoic structure of the southern IBR} accretionary prism (e.g. Moore et al., 2019) before colliding with India, and evolving into a sub-aerial fold and thrust belt. However, the early Paleogene marks the end of a tectonic phase where the IBR/West Burma Terrane were translated from $5^{\circ} \mathrm{S}$ to $4^{\circ} \mathrm{N}$ and rotated $60^{\circ}$ (Westerweel et al., 2019). Hence deformation during phase may have included considerable strike-slip or oblique-slip motion, not just simple plate convergence. The differentiation in behaviour that is now characteristic of the IBR (see section 3.6) developed during the Palaeogene, as the history of convergence with India affected different parts of the margin in different ways. In particular there is a pronounced transition in structural style around $19^{\circ} 30^{\prime}$ N., where north of this latitude structures (folds, thrusts, strike-slip faults) tend to be subparallel to progressively divergent (Figs. 1 and 21). More NNW-SSE oriented structures occur 653 in the outer belt (Fig. 1), and more N-S trending structures are present in the inner belt (Fig. 654 21). There is also a clockwise rotation in structural orientation passing northwards within the 
IBR (Fig. 1). But altogether the IBR north of $19^{\circ} 30^{\prime} \mathrm{N}$ exhibits a low divergence of structural orientations compared with the area to the south. In the Ramree Island area there are the circular and elliptical fold features in Cenozoic deepwater sedimentary rocks with a variety of orientations indicative of deformation of mobile, overpressured shale-prone sequences (e.g. Maurin and Rangin, 2009; Moore et al., 2019). This structural style coincides with a belt of deformation in the northern part of the southern area (south of $19^{\circ} 30^{\prime} \mathrm{N}$ ) where strong NW-SE trends in bedding and strike-slip faults are present (Nielsen et al. 2004; Rangin, 2017; Figs. 25, 26), The trends are particularly strong on the western side of the belt, and are more N-S oriented at the eastern margin of the IBR (Fig. 25C,D). Rangin (2017) calls this the PlayProme Shear Zone, and relates this zone to a major tectonic boundary between an accreted Indian Ridge to the south, and the Burma Platelet to the north. Passing further south the IBR curve to an overall NNE-SSW trend (Fig. 25). Most of the IBR are located offshore in the south and only the eastern-most part of the belt is observed onshore.

A series of NNE-SSW to N-S trending linear strike-slip faults affect the onshore area (Fig. 26B), and passing westward faults and bedding tend to curve to a NW-SE orientation, with dextral strike-slip faults curving into NW-SE thrusts (Figs. 25,26). This deformation pattern was shown to a limited extent by Nielsen et al. (2004), now higher resolution satellite data shows a high density of structures with these characteristics (Fig. 25). Offshore, north of $\sim 19^{\circ} 30^{\prime} \mathrm{N}$, the Outer IBR are characterised by relatively simple folds in the Neogene section (Figs. 1 and 25A; Jain et al. 2010). To the south the Rakhine margin is very different. Offshore, west of the Irrawaddy Delta, Oligocene-Recent sand and shale -dominated sequences overlie Eocene Carbonates, indicating a transition from the extensive Eocene clastics onshore in both the IBR and Central Basin. The high Oligocene-Pleistocene clastic sediment load caused the development of gravity-driven, listric normal fault-bounded depocentres that were episodically inverted (Fig. 25B,D). The development of such inverted 
depocentres is known from some other forearc basins (e.g. Hawkes Bay, New Zealand, Barnes et al. 2010; the Makran, S. Asia, Back and Morley, 2017). However, overall the Rakhine margin does not resemble a classic accretionary prism-forearc basin, where for example in the Hawkes Bay and Makran examples the accretionary prism fold and thrust belts are considerably better developed than the narrow zone present on the Rakhine margin. The reason for the differences reflect the strike-slip dominated nature of the Rakhine margin (e.g. Rangin, 2017, 2018), where the eastern belt of strike-slip and thrust faults accommodates most of the plate motion, leaving less structural activity in the offshore slope region (Nielsen et al., 2004), coupled with the high rates of sedimentation leading to gravity-driven deformation on the shelf. The narrow, deepwater fold and thrust belt offshore at the transition to the flat-lying abyssal ocean floor, that has developed since the Eocene appears to be a mixture of gravitydriven fold and thrust structures, large-scale mass wasting features, and basement-involved strike-slip structures (e.g. Nielsen et al., 2004; Rangin, 2018).

The anomalous region of deformation between the Nicobar Islands to the south and the latitude of $19^{\circ} 30^{\prime} \mathrm{N}$ to the north, is interpreted here as a lithosphere-scale transfer zone between Indian Oceanic crust subduction to the south, and subduction of the Neotethys remnant (or thinned Indian continental crust) to the north, where there is evidence for a short slab dipping between $25^{\circ}-60^{\circ}$ down to about $160 \mathrm{~km}$ depth (e.g. Stork et al., 2008; Pesicek et al., 2010; Sloan et al., 2017). There is virtually no deep (>50 km) seismicity, in this region of anomalous deformation (Rangin, 2017; Sloan et al., 2017), where mantle tomography and gravity modelling suggest there is no subducting slab (Rangin, 2017; Yadav and Tiwari, 2018). Consequently, this region appears to be absent of Oligocene-Neogene (?) subduction (Rangin et al., 2013). The Neotethys slab has detached, leaving a remnant slab dominated by NNESSW dextral strike-slip motion (Nielsen et al., 2004), overlain by an orogenic wedge where strike-slip faults splay and curve anti-clockwise into thrusts. 
The West Burma Terrane, including the Indo-Burma Ranges has been subject to a

great variety of restorations regarding its tectonic position, and when and how it collided with SE Asia (Table 2; see reviews in Searle et al., (2017) Barber et al. (2017). Recently, two new constrains on the palaeo-position of the West Burma Terrane have been developed, concerning palaeomagnetic data for the West Burma Terrane, and provenance data for the Pane Chaung Formation as discussed below.

A recent, detailed, palaeomagnetic study of well-dated Late Cretaceous igneous and Eocene sedimentary sequences in the Wuntho-Popa Arc indicates that West Burma lay around $5^{\circ} \mathrm{S}$ in the Late Cretaceous $\left(97-87 \mathrm{Ma}\right.$ ), and $4^{\circ} \mathrm{N}$ in the Late Eocene (Westerweel et al., 2019). These palaeo-positions mark two key periods in the development of the IBR. The Late Cretaceous paleolatitude imposes constraints on models for the Pane Chaung Formation, and ophiolite development. While the Late Eocene paleolatitude occurred at the time when the accretionary history of the IBR was largely finished and significant dextral strike-slip motions about to be superimposed on the area. Between the Late Cretaceous and Late Eocene palaeo-positions West Burma underwent a drift of c. $9^{\circ} \mathrm{N}$, and also c. $60^{\circ}$ clockwise rotation (Westerweel et al., 2019).

The Pane Chaung Formation shows very similar fossil, sedimentary, provenance (recycled orogen), and detrital zircon provenance characteristics (zircon ages, $\varepsilon_{\mathrm{Hf}}(\mathrm{t})$ values) with the Langjiexue Group (Wang et al., 2016). This in turn implies deposition adjacent to the Indian area of northern Gondwana during the Late Triassic (Cai et al., 2016; Wang et al., 2016). Based on the $5^{\circ} \mathrm{S}$ palaeo-position of the Wuntho-Popa arc, and the correlation of the Pane Chaung Formation with the Langjiexue Group (exposed south of the YarlungZangbo Suture in South Tibet), two basic scenarios for the depositional location of the Pane 
Chaung Formation can be proposed: 1) The Pane Chaung Formation was part of the future NE Indian Continental margin within northern Gondwana (Wang et al., 2016). 2) The Pane Chaung Formation was deposited on the West Burma Terrane, which in the Late Triassic, was located on northern Gondwana adjacent to the future NE region of NE India. In both these scenarios the unconformity with the Albian-Cenomanian limestone (i.e. in the broad age range of 110-95 Ma), of the Paung Chaung Formation, is an important constraint

A) The IBR are underlain by Indian Oceanic crust, ophiolites marking the Tethys suture were emplaced during the Maastrictian, and underlie the western part of the Central Basin, and subsequent strike-slip deformation has considerably modified the area (Rangin et al., 2013; Rangin, 2018).

B) The IBR are underlain by Indian Oceanic crust. Ophiolites marking the Tethys suture were emplaced prior to the Aptian-Cenomanian unconformity (overlain by mid-Cretaceous limestones), onto a micro-plate (Mt Victoria Land), rifted from India, and bearing the Triassic Pane Chaung Formation and Kanpetlet Schists. The 
microplate subsequently collided with the West Burma Terrane, at around $5^{\circ} \mathrm{S}$ in the Late Cretaceous.

C) Accretionary prism model for the IBR-West Burma Terrane where the ophiolites are accretionary-type, and have been emplaced as slices at various times during Jurassic-Eocene subduction (Harlow et al., 2014; Fareeduddin and Dilek, 2015; Hla Htay et al., 2017; Barber et al., 2017). The Pane Chaung and Kanpetlet Schists were deposited on the West Burma Terrane, which lay adjacent to NE India in Northern Gondwana, during the Triassic.

D) Accretionary prism model for IBR-West Burma terrane, where ophiolites are accretionary-type. The accretionary prism built out from the Sunda margin since Jurassic times (Zhang et al., 2018).

The provenance data on the Pang Chaung Formation and the Late Cretaceous palaeoposition of the West Burma Terrane do not fit with the Sunda margin origin for D) above, so this model will not be discussed further. A key difference between model A, and models B and $\mathrm{C}$ is that in $\mathrm{A}$ ) ophiolite emplacement is viewed as occurring during the Maastrictian. This interpretation runs up against two contradictory pieces of information: 1) ophiolite fragments unconformably underlie the Paung Chaung Formation in the Southern Chin Hills, indicating some ophiolite emplacement pre-dates the mid-Cretaceous (United Nations, 1979; Mitchell, 1993; Mitchell et al. 2010; Appendix 1). 2) In the Kalemyo area, at Webula Bula the metamorphic sole (indicative of the timing of emplacement) is dated around -114-119 Ma (Table 1; Zhang, J. et al., 2017, 2018). For Maastrictian emplacement to be viable, an alternative explanation to the field observations made in United Nations (1979) must be offered. But even if this is done, the age of the metamorphic sole does not fit with Maastrictian emplacement. Some more regional evidence for Early Cretaceous tectonic activity also needs to be considered. Advocaat et al. (2018) indicate the Woyla Arc collision 
with Sumatra was diachronous between $113 \mathrm{Ma}$ and $95 \mathrm{Ma}$. The onset of collision at $113 \mathrm{Ma}$, to the east of the West Burma Terrane, is close to the age of the Paung Chaung Unconformity $(\sim 105 \mathrm{Ma})$ in the southern IBR, and formation of the metamorphic sole in the Kalemyo region ( 114-119 Ma, Table 1; Zhang et al., 2017). Indicating a possible link between that unconformity, ophiolite emplacement and the Woyla Arc collision. Peak igneous activity in the Wuntho-Popa arc was reached around $100 \mathrm{Ma}$, then declined (Fig. 28)

Model B (Fig. 27), is constructed to fit the constraints imposed by a) Pane Chaung provenance (Wang et al., 2016), b) the 95 Ma palaeolatitude of the West Burma Terrane (Westerweel et al., 2019), and c) the Aptian-Cenomanian limestone unconformity (United Nations, 1979). Around $95 \mathrm{Ma}$ West Burma was located at $5^{\circ} \mathrm{S}$ at $95 \mathrm{Ma}$, which is too far northwest to collide with India (Fig. 29). Hence, collision with a microcontinent rifted from the Indian Plate, and moving ahead of India is required instead (Fig. 29). This microplate fits with the concept of the Pane Chaung Formation and Kanpetlet Schists originating on a terrane known either as Mt Victoria Land or the Burma micro-block (Mitchell, 1985; Acharrya, 2007; Rangin et al., 2013). The Indian Plate origin requires ophiolite emplacement onto Mt Victoria Land prior to collision with West Burma (Fig. 29A). However, there is only a limited area of thickened crust in the IBR (Appendix 2), and the microplate would have to be a narrow strip, of thin crust to fit (Fig. 27B). The scenario is convoluted, but it indicates the issues required to honour all the key data. The problems with the scenario may well be indicating that one or more key constraints are not viable.

Scenario C (Figs. 27C, and 30), addresses two issues with the previous models: 1) timing of ophiolite emplacement, and 2) an Indian plate origin for the Pane Chaung Formation, but without the problematically narrow Mt Victoria Land microplate. In scenario C ophiolites were emplaced episodically as accretionary (Franciscan)-type (see section 2.1.1 Ophiolites), that are not associated with collision or obduction (Harlow et al., 
2014; Fareeduddin and Dilek, 2015; Hla Htay et al., 2017; Barber et al., 2017) The West Burma Terrane is considered to have been positioned next to India, in Gondwana, and rifted off, carrying part the Pane Chaung Formation province with it. In such scenario, there is then the problem of how to work the Pane Chaung Formation into an accretionary prism setting (Fig. 30 A,B).

Which of the scenarios A-C are more appropriate, or if a new scenario is needed, remains uncertain, but can be addressed through further palaeomagnetic work, improved understanding of ophiolite development, dating of metamorphism in the Kanpetlet Schists and a better understanding of the Pane Chaung Formation depositional systems.

Between $90 \mathrm{Ma}$ and $80 \mathrm{Ma}$, subduction of the fast-moving Neo-Tethys part of the Indian Plate commenced, as India rifted from Madagascar (c. $90 \mathrm{Ma})$, and between 80-65 Ma moved northwards at rates exceeding $15 \mathrm{~cm} / \mathrm{yr}$ (see review in Zahirovic et al., 2016).

Curiously, this time period is marked by an absence or marked decline in igneous activity in the Wuntho-Popa arc (Fig. 28), suggesting it was not experiencing subduction below the arc at this time. Instead, important strike-slip translation and rotation of West Burma may have occurred between $80 \mathrm{Ma}$ and $65 \mathrm{Ma}$, which is marked by deposition of the Falam Formation. The period between $70 \mathrm{Ma}$ and 60 Ma coincides with the Paunggyi Conglomerate unconformity, erosion of ophiolites (uplift of the forearc basin), and the emplacement of the Sin Chaung Exotics (mélange) (Fig. 30D; see Appendix 1 for details of the unconformity and Sin Chaung Exotics).

Deepwater depositional conditions in the IBR persisted into the Middle Eocene. A major change occurred when the Naga ophiolitic melange complex was eroded, and the ophiolite clast-rich Jopi-Phokpur Formation (molasses) was unconformably deposited over the Late Cretaceous-Middle Eocene flysch deposits and ophiolites (Figs. 28, 30; Ghose et al., 
2014). In the northern IBR this collision has continued to the present day, while further south, the collision was transient or avoided (e.g. Nicobar and Andaman islands). The transition from a submarine to a sub-aerial fold-and-thrust belt in the northern part of the IBR started around the time (c.40 Ma) when West Burma was located approximately $4^{\circ} \mathrm{N}$ (Westerweel et al., 2019).

In order to move West Burma $2100 \mathrm{~km}$ north, from $4^{\circ} \mathrm{N}$ at c. 40 Ma to $24^{\circ} \mathrm{N}$ today, requires an average velocity of $5.2 \mathrm{~cm} / \mathrm{yr}$. This rate is in line with the velocity history of the Indian Plate for the same time period, which moved northwards by $\sim 2400 \mathrm{~km}$ (average velocity $6 \mathrm{~cm} / \mathrm{yr}$; e.g. O’Neill et al., 2005; van Hinsbergen et al., 2011). The comparable velocities, palaeolatitude data, and onset of molasse deposition suggest West Burma was coupled with India by the Late Eocene. In Figure 31 this coupling is shown as occurring by the collision of the northern part of the Western Burma Terrane with a promontory of Greater India. Such a promontory is suggested by the interpretation that the Bay of Bengal is partially underlain by hyper-extended, underplated and intruded, continental crust (Sibuet et al., 2016), not oceanic crust. One issue is how the ocean closed up on the east side of West Burma, and Sundaland (Fig. 31), for which evidence for ophiolites, or an accretionary prism in the Shan Scarp region is lacking. However, there is evidence for Late Cretaceous-Paleogene arcrelated volcanism, and some metamorphism along the western margin of the Shan Plateau, and Peninsula Myanmar and Thailand (see reviews in Morley, 2011 and Gardiner et al., 2015, 2018). The issue of evidence for ocean closure can be mitigated by moving the eastern margin of West Burma along a transform margin (Fig. 31). The presence of a transform margin, called the I-A Transform, has been proposed by Hall (2012) to accommodate the marked difference in velocity during the early Palaeogene between the fast moving Indian Plate, and the slow moving Australian plate. The I-A Transform also fits well with the rapid northwards displacement of the West Burma Terrane, required by the palaeomagnetic data 
851 (Westerweel et al., 2019). The Sagaing Fault has traditionally been regarded as a relatively 852 young feature (Middle Miocene or younger), while the Shan Scarp marks an older major 853 Cenozoic strike-slip fault zone (e.g. Bertrand et al, 2001; Bertrand and Rangin 2003, Sloane 854 et al., 2017). The only suitable location for the eastern margin of the West Burma terrane as 855 far back as the Late Eocene is somewhere between the Sagaing Fault and the Shan Scarp 856 Fault, and is simplest if the Shan Scarp Fault (Bertrand and Rangin, 2003) marks the boundary. Whether that interpretation can be justified by field evidence requires further study.

The Oligocene period is marked by E-W extension in the eastern Andaman Sea, and 860 activity along, at least, the northern part of the Sagaing Fault (Morley and Arboit, 2019). The Palaeogene section of the IBR and Central Basin is primarily sourced from the Wuntho-Popa Arc, and only during the Neogene did the Himalayas become a significant source of sediment for the Central Basin (e.g. Allen et al., 2008; Wang, J.-G., et al., 2014; Kyaw Linn Oo, 2015; Licht et al., 2018). This shift indicates when, during northwards motion the West Burma Terrane was finally close enough to connect with drainage from the Himalayas, coupled with onlap and covering of the Wuntho-Popa arc by Oligocene-Miocene sediments in the Pegu Yoma.

During the Early Miocene-early Late Miocene the Central basin experienced NNWSSE oriented, dextral transtensional deformation that resulted in numerous ENE-WSW trending normal faults, following R' shear orientations (Morley and Searle, 2017). Such faults are known to be extensively present further south in the East Andaman Basin, where they are of Early Miocene-early Middle Miocene age (Curray, 2005; Srisuriyon and Morley, 2015; Morley, 2017). A switch to more transpressional deformation occurred during the Late Miocene in the Central Basin, which gave rise to the major hydrocarbon-bearing anticlines in the basin (Pivnik et al., 1997; Bertrand and Rangin, 2003). This significant change in 
structural style can be viewed as symptomatic of major regional structural changes in the Indo-Burma Ranges. Following coupling with India around $40 \mathrm{Ma}$, and a period of shortening that lasted into the Early Oligocene, subduction along the IBR would have ceased (Rangin et al., 2013). To maintain a similar displacement velocity as India, requires little significant deformation between the IBR and India, with virtually all displacement focussed on the eastern margin of the West Burma Terrane. This lack of tectonic activity in the IBR is seen by the development of Oligocene-Miocene listric-normal fault controlled depocentres in the offshore Rakhine area (section 3.7; Rangin, 2018). However, by the Late Miocene, the dextral motion between West Burma and Sundaland became increasingly resisted. Relative motion changed from $>90 \%$ of Indian Plate motion (as required by the translation of the West Burma block north, Westerweel et al., 2019) to $c .50 \%$ (as indicated by modern displacement rates on the Sagaing Fault, see review in Rangin et al., 2013). This change resulted in the onset of transpressional deformation within the Central Basin, and the strong Late MioceneRecent dextral-transpressional deformation of the Indo-Burma Ranges, described here and in Maurin and Rangin (2009). The $300 \mathrm{~km}$ discrepancy in northwards motions between India (2400 km motion) and West Burma $(2100 \mathrm{~km})$, could be explained by c. $200 \mathrm{~km}$ dextral motion between India and West Burma from 10 Ma-Present (i.e. 50\% of current plate motion), and c. $100 \mathrm{~km}$ dextral motion for the period between $40 \mathrm{Ma}$ and $10 \mathrm{Ma}$.

\section{Post-Eocene subduction of Indian Plate oceanic crust has occurred at a high rate} below Sumatra, while passing north the amount of subduction beneath West Burma/Sundaland decreased to zero, with the slab being absent north of the AndamanNicobar islands (e.g. Rangin et al., 2013; Yadav and Tiwari , 2018; Rangin, 2018) and displacement was transferred onto the I-Y Transform margin (Fig. 31). The region where subduction is absent in the offshore, southern IBR coincides with the area of anomalous structure in the southern IBR, that lies south of 19³0' $\mathrm{N}$ (section 3.4.). 


\section{Discussion and Conclusions}

The IBR is a key modern example of an active orogenic wedge that evolved from a

904

905

906

907 complex accretionary prism setting and now lies highly oblique to a major orogenic belt. The early history of the IBR is critical for understanding the tectonic evolution of the eastern Tethys ocean. While the post-collisional history is important for demonstrating the response of an orogenic wedge to prolonged ( $>40 \mathrm{my}$ ) transpressional deformation. This response includes atypical retro-wedge development and development of a crustal-scale strike-slip transfer zone between two regions of oblique subduction.

An accretionary-type origin for some of the highly dismembered, variable size fragments of oceanic lithosphere present in the IBR is favoured here (e.g. Fareeduddin and Dilek, 2015; Ki Khin et al., 2017; Zhang, J. et al., 2017), where slivers of oceanic lithosphere are emplaced within an accretionary prism as part of an ongoing processes (e.g. skinning, extrusion from a subduction channel) during subduction. This origin does not require specific collisional events to be associated with the emplacement of oceanic crust fragments. However, the possibility needs to be considered, that the Pane Chaung Formation was deposited on an India-related microcontinent, that collided with the West Burma Terrane in the late Early Cretaceous, following a phase of ophiolite obduction. We suggest that the Naga hills - Kalemyo zone of ophiolites represents a broad, complex suture zone that marks the closing of a succession of back-arc and major ocean basins in the Tethyian realm, and marks the India-Asia suture zone in Myanmar. The zone contains fragments of Cretaceous oceanic lithosphere, Mesozoic radiolarian cherts, alkali volcanic rocks and mélanges very similar to the IYSZ in Tibet. From the review by Hebert et al. (2012) key events in the IYSZ comprise: 1) a subduction-related Jurassic intra-oceanic arc formed around 180-150 Ma, 2) around 130- 
$88 \mathrm{Ma}$ a fast-spreading intra-arc ridge developed related to slab rollback, high pressure metamorphics were exhumed, and the intra-arc basin provided most of the Yarlung suture zone relicts, 3) Late Cretaceous obduction of the intra-arc basin and remnant arc onto the active arc. The timing of these elements in the IYSZ is very much in line with the IBR, with the Jurassic events in the Inner Belt and Jade Belt (180-150 Ma); the 130-115 ages of Kalemyo and Naga oceanic lithosphere fragments, and the $\sim 90$ Ma Kabaw Formation, Paung Chaung Formation unconformity (Fig. 28). In more detail the history of arcs, microplates, and back-arc basins in the IYSZ and IBR are different. The scenario where Mt Victoria Land collides with the West Burma Terrane in the mid-Cretaceous is one such difference.

Exhumation and erosion of the ophiolites, outside of the Mt Victoria Land collision, is unrelated to obduction, but instead marks periods of uplift and erosion of the former accretionary prism associated with India-West Burma collision, West Burma-Sundaland transpressional convergence, and plate re-organizations.

The history of deformation in the Indo-Burma Ranges includes extensional faulting close to the time of deposition of the Pane Chaung Formation during the Late Triassic to Early Jurassic. The tectonic position of the Pane Chaung Formation is key to understanding the early history of the IBR, but remains controversial (Table 2). We prefer two scenarios, either deposition on Mt. Victoria Land, or on West Burma Block that in either case lay adjacent to NE India within Gondwana, but further data is needed to discriminate between them. Fragmentary geochronological evidence from a few poorly located metamorphics from the Jade Belt region suggests ocean floor was generated during the Early Jurassic, while subduction generated high pressure-low temperature metamorphism around $150 \mathrm{Ma}$ (Table 1). Much more substantiation of this early history is necessary. The issues of the Pane Chaung palaeogeographic setting, and Jurassic ophiolite development have a profound 
impact regarding how plates are reconstructed on the SE Asian margin during the early Mesozoic (Section 4.).

Probably much of the metamorphism and deformation in the Kanpetlet Schists occurred between the Jurassic and mid-Cretaceous, since clasts of ophiolitic material and schist are found in the Paung Chaung Formation and the Sin Chaung Exotics (United Nations, 1979a; Appendix 1). The gap in preserved, or exposed deposits of Late Jurassicearly Late Cretaceous age in the IBR is highly problematic to explain in the context of a prolonged accretionary prism story, and are simplest to explain in the Mt Victoria Land collision scenario. The peak of Wuntho-Popa Arc volcanism around 100 Ma (e.g. Mitchell, 2017; Gardiner et al., 2015, 2018) indicates active subduction in the vicinity of the IBR/West Burma Terrane. Around 84 Ma deposition of the Falam and Kabaw Formation was initiated, both formations unconformably overlie the Pane Chaung Formation. The Pane Chaung Formation was subject to a more complex history of superimposed folding and faulting than the overlying Falam Formation. Both the Falam and Chunsung Formations are thought to be related to subduction of the Neo-Tethys oceanic crust, with deformation decreasing in intensity from the Falam to the Chunsung formations. However, the Campanian-Maastrictian decline in Wuntho-Popa arc activity, does not fit well with a simple Late Cretaceous subduction setting for the IBR. The tectonic setting for this period is not well understood, but requires both northwards translation of Western Burma of around $9^{\circ}$ from $5^{\circ} \mathrm{S}$, along with $60^{\circ}$ rotation during the period from $95 \mathrm{Ma}$ to $45 \mathrm{Ma}$ (Westerweel et al., 2019).

India probably coupled with western Myanmar around 46- $40 \mathrm{Ma}$, subduction was halted, and widespread uplift and erosion is marked by Late Eocene-Oligocene molasse deposits that unconformably overlying flysch, ophiolite and metamorphic units. Highly oblique motion of India with respect to SE Asia resulted in extensive development of strikeslip faults (Rangin et al., 2013; Rangin, 2017, 2018). During the Late Miocene-Recent strike- 
slip deformation became increasingly important within the Central Basin, and probably also affected the Core region (Figs. 7C, 11, 16, 18; Keng, North and South Kabaw faults).

Sedimentary provenance studies indicate the Palaeogene section of the Central Basin and IBR was predominantly locally sourced from the Wuntho-Popa Arc, whereas Himalayan sources became more important during the Neogene (Allen et al., 2008; Wang, J.-G. et al., 2014; Kyaw Linn Oo et al., 2015; Licht et al., 2018).

The present day topography of the sub-aerial wedge is very different from its past history as a submarine wedge. Variations in average surface slope angle reflect the changing nature of the basal detachment, impingement of the wedge on adjacent highs (Shillong Hills, Eastern Himalayas) and development of a highly oblique slip core zone, with some modified retro-wedge features. The Kabaw Fault, which has been considered as a key component of the retro-wedge, is not a continuous feature, and should be considered as at least two separate faults (the North and South Kabaw fault zones). Departures of the IBR from retro-wedge development in pure convergence analogue models include: 1) late retro-wedge vergent structures have migrated towards the inner ranges with time to become superimposed on prowedge vergent structures. 2) Late transpressional overprinting of the retro-wedge area is the dominant structural style.

The southern IBR developed a structural style during the Oligocene-Recent (Fig. 25) that is dissimilar to the IBR north of $19^{\circ} 30^{\prime} \mathrm{N}$, and most accretionary prisms/orogenic wedges. This style is characterised by transpressional structural geometries onshore, episodically inverted gravity-driven listric normal fault systems offshore and only a very narrow, probably gravity-driven deepwater fold and thrust belt (Fig. 26). The cause is inferred to be a late Eocene to post-Eocene lithospheric-scale strike-slip zone (e.g. Rangin et al., 2013, Rangin, 2017) that acted as a transfer zone between two regions of oblique subduction to the $\mathrm{N}$ and $\mathrm{S}$. 


\section{Acknowledgements}

1002

We would like to thank three anonymous reviewers and Mike Crow for detailed, constructive comments that helped improve the manuscript. Ophir Energy, London, are gratefully acknowledged for funding the Ph.D. project of TTN, and the associated fieldwork in the IBR, Chiang Mai University are gratefully acknowledged for funding travel expenses of CKM.

Alexis Licht, Pierrick Roperch and Jan Westerweel are thanked for helpful discussions regarding the geology of Western Myanmar. Andrew Mitchell and Claude Rangin are thanked for many helpful, insightful, and spirited discussions of the geology of Myanmar over many years.

Appendix 1 : Evidence for the timing of key unconformities in the Indo-Burma Ranges

Mesozoic-Cenozoic unconformities associated with the Indo-Burma Range have been established on the basis of 5 main observations: 1) map relationships, 2) presence of key provenance indicators (e.g. ophiolite-derived clasts) in the sedimentary units overlying the unconformity, 3) a decrease in structural intensity and/or metamorphic grade above and below the unconformity, 4) time gap between adjacent units, and 5) direct observation of an unconformable relationship (e.g. angular unconformity) in the field. However, often 5) is not demonstrable due to limited exposure. Early workers have remarked on the close coincidence between Cretaceous outcrops and ophiolites, for example according to Clegg (1941) 'in every locality where Cretaceous sediments are exposed, peridotites, or serpentinites are invariably

1021 found'. Suggesting that the Cretaceous was a key time for ophiolite emplacement. We address the key Cretaceous and Palaeogene unconformities below. 
Perhaps the most important, because it is the oldest, and most contentious

1025

1026

1027

1028

1029

1030

1031

1032

1033

1034

1035

1036

1037

1038

1039

1040

1041

1042

1043

1044

1045

1046

1047

unconformity is the one between the Paung Chaung Formation and the stratigraphy of the Eastern Belt (i.e. Kanpetlet Schists, Pane Chaung Formation, ophiolites, ophiolite mélange).

The map relationships of the Paung Chaung Formation are mostly known as a result of extensive mapping in the Chin Hills area (United Nations, 1979, Mitchell et al., 2010; Mitchell, 2017). The Paung Chaung Formation was first described in the Chin Hills area by Gramman (1974), who identified the formation over a distance of $50 \mathrm{~km}$. The name of the formation is derived from the Paung Chaung stream, that lies $7 \mathrm{~km} \mathrm{NW}$ of Saw (Fig. 22B). Typically, the unit has a maximum stratigraphic thickness of $200 \mathrm{~m}$, dips eastwards up to $70^{\circ}$, is variably affected by weak to strong folding, and lies in a tectonically repeated belt, up to 800 m wide, (United Nations, 1979a). The Paung Chaung Formation appears sporadically below another unconformity at the base of the Kabaw Formation (Fig. 2). Gramann (1974) identified three fossiliferous horizons from the limestones in the Saw region (Fig. 22B) that suggest a late Aptian to Cenomanian age. The Albian-Cenomanian Limestone is unconformably overlain by the Campanian-Maastrictian Kabaw Formation and locally by clastics and minor limestones of the Paunggyi Formation (United Nations, 1979).

The Paung Chaung Formation is interpreted as being laterally equivalent to other limestone and clastic sequences of Aptian-Cenomanian age that are present in northern Myanmar. These include the amber-bearing clastic-carbonate sequences in the Hukawng Basin (Cruickshank and Ko, 2002), and the Orbitolina-bearing limestones of the Naga Hills, Jade Belt, and Myitkyina-Tagung areas (Clegg, 1941; Brunnschweiler, 1966; Chit Saing, 2000). According to Chit Saing the Orbitolina-bearing limestones were deposited in shallow marine to protected lagoonal environments and are represented by the Nanhkolon, Namakauk and Taungbwet Taung formations. 
1050 Chaung Formation on the east side of the Chin Hills. Mapping by the United Nations (1979)

project shows that the Pane Chaung Formation outcrops immediately below the Paung

Chaung Formation. Dips in the Pane Chaung Formation are highly variable due to folding, and range between overturned beds dipping between $16^{\circ}$ and $70^{\circ}$, and right way up, dips are predominantly eastwards. The overlying Paung Chaung and Kabaw Formation are folded, but are less deformed, with no overturned beds, and dips commonly around $25-36^{\circ}$ east (United

Nations, 1979). Hence both the map relationships and the intensity of deformation indicate an unconformity between the Paung Chaung Formation and the Pane Chaung. Examples of a 1058 clear exposure of the unconformity are not known (United Nations, 1979). However, at the junction of the Mahin and Ngahamaing Chaungs, south of Shwelegyin, east-dipping black laminated limestones (Paung Chaung Formation) are underlain by green pillow lavas, with a serpentinte sheet, and quartz-dolomite rock present at the contact (United Nations, 1979; Fig. A1 location X). The basal limestone in the Saw area is also reported to contain clasts of Pane Chaung Formation sandstones, basaltic pebbles (inferred to be derived from pillow lavas), serpentinite sand, and lava pebbles (United Nations, 1979; Mitchell, 2018).

Quartz-dolomite-+/- chromium-rich mica rocks (listwanites) and quartz-carbonate rocks (ophicalcite) are reported (United Nations, 1979) as sometimes occurring between pillow lavas and the Paung Chaung Formation. Such rocks are typically the product of CO2bearing hydrothermal fluids encountering and reacting with serpentinized mafic and 1069 ultramafic rocks (Kashkai and Allakhverdiev, 1965; Sherlock et al., 1993; see review in 1070 Hansen et al, 2004), 

explanation is that the Kabaw Fault defines the contact. However, map and satellite analysis indicates the South Kabaw Fault dies out south of Laungshe (Fig. 23) and that an unconformity is present in the Saw area (as interpreted in United Nations, 1979). section has an upper Albian-Cenomanian age, similar to the Orbitolina limestones (Cruickshank and Ko, 2002). Dating of zircons from lithic clasts associated with the amberbearing sedimentary rocks indicates the presence of volcanism in the area around $100 \mathrm{Ma}$, and a maximum depositional age of $98.8 \pm 0.62 \mathrm{Ma}$ (Shi et al., 2012). This volcanism is consistent with the known timing of magmatic activity in the Wuntho-Popa Belt (see Gardiner et al., 2018 for a review). The lithologies in the amber mines are shallow marine shales, carbonaceous sandstones, minor limestones and conglomerates (Cruickshank and Ko, 2002). These deposits are tightly folded, and contain clasts of chert, andesite, basalt, serpentinite and actinolite schist, suggesting an ophiolite source (Cruickshank and Ko, 2002). These authors mention the presence of Cretaceous limestones $45 \mathrm{~km}$ south of the amber mines at Noije Bum, in the Jade Belt, that contain Orbitolina and amber (at Nam Sakahw). The Jade Belt geological map (Fig. A2) shows Jade-bearing ultrabasic rocks surrounded by metamorphic units, that are unconformably overlain by Cenozoic sediments (Thet Tin Nyunt, 2017; pers comm. 2018). In a few places Cretaceous Orbitolina Limestones occur along the unconformity or emerge from beneath the Cenozoic cover (Fig. A2 inset), indicating a substantial phase of erosion prior to Cenozoic deposition, where the Cenozoic sediments onlap and covered erosional remnants of the Orbitolina Limestones. According to Thura Oo 
and Chit Saing (2000) the Jade Belt limestones contain fossils of the Orbitolina (Mesorbiolina) texana Zone, which is of early Albian age.

The common characteristics to the accounts of the Albian-Cenomanian deposition in Jade Mines and Chin Hills area include: 1) the presence of ophiolite-derived clasts in the section. 2) The deposits lie unconformably on Triassic sedimentary rocks of the Pane Chaung Formation or on metamorphics. 3) The Cretaceous section is strongly folded. 4) The Cretaceous section is discontinuously present below the overlying sedimentary unit indicating an episode or episodes of uplift and erosion during the Late Cretaceous and Palaeogene.

\subsection{Kabaw Formation and Paunggyi Conglomerate}

There is some uncertainly regarding the stratigraphy of the Paunggyi Conglomerate and the Kabaw Formation. In the United Nations (1979) report, the Paunggyi Conglomerate was assigned a Late Cretaceous-Eocene age, but it was recognised that there was an internal unconformity to the formation, with the Palaeocene being largely absent. More recently only the Eocene part of the sequence is called the Paunggyi Conglomerate (Thiengi Kyaw, 2005). However, further constraints by fossils and minimum depositional ages from detrital zircons indicate the age of the Paunggyi Conglomerate is upper Maastrichtian to Palaeocene, while the overlying Laungshe Formation is uppermost Palaeocene to Lower Eocene in age (Wang, J.-G. et al., 2014; Licht et al. 2018)

In the Saw-Mindat area, the lowest exposure of what the United Nations (1969) mapped as the Paunggyi Conglomerate lies 20 m east of the Paung Chaung Formation, in the Paung Chaung stream, and comprises sandstones, and grits with foraminifera of late Cretaceous, probable Maastrictian age (United Nations, 1979). Higher up in the stream are interbedded orthoconglomerates that contain pebbles and conglomerates composed of chert, basalt, gabbro, greenschist, mica-schist and serpentinite. In the stream Maw Chaung (Fig. 2) 
the base of the formation is a well sorted pebble bed that rests directly on serpentinite in some localities and Paung Chaung Limestone in others, while in Yethaya Chaung the formation overlies pillow lavas and serpentinites (United Nations, 1979). Rangin (et al., 2013) also report Maastrictian Stage Globotruncana in the matrix of the Kabaw Conglomerate which contains ophiolite-derived clasts. They infer that this marks the time of obduction of Mesozoic ophiolites onto the Mount Victoria terrain. Gramman et al. (2011), note that west of Mindon a Campanian-Maastrichtian age conglomerate (they call basal Paunggyi Conglomerate) directly overlies a body of serpentinite.

Zhang et al. (2017) show a photograph, from the Saw area, of the Kabaw Formation (calcareous sandstone) overlying more strongly deformed Pane Chaung Formation, with an angular discordance. We have observed ophiolite-derived clasts in the Kabaw Formation east of Kalemyo (Figs. 3, 20F).

In the eastern foothills of the Chin Hills around the confluence of the Sin Chaung and Maw Chaung rivers there is the $2 \mathrm{~km}$ wide Sin Chaung Exotics Zone (United Nations, 1979; Figs. 2 and A1). This zone comprises red and green clays, blocks of chert, Pane Chaung sandstone, gabbro, basalt, conglomerates with basalt, and gabbro clasts, serpentinite, ophicalcite, and marble, together with rafted blocks of Senonian (Globotruncana) micritic limestone. Folding of the Pane Chaung Formation and metamorphism of the Kanpetlet Schists is considered to be pre-Campanian because exotic blocks of schist are present in the Exotic Blocks mélange, which is interpreted to be of Campanian-Maastrictian age (United Nations, 1979).

The eastern margin of the Sin Chaung Exotics is overthrust by Pane Chaung Formation. Most critically the Pane Chaung Formation is unconformably overlain by limestones of the Paung Chaung Formation, and Kabaw Formation (Gramman, 1974; United 
Nations, 1979). West of the Sin Chaung Exotics, sub-vertical Paung Chaung Formation

1144 limestone is present, associated with vertical serpentinite sheets, with possible Paunggyi

1145 Conglomerate east of the limestone (United Nations, 1979). There is a $100 \mathrm{~m}$ gap between

1146 these units and exposures of the Sin Chaung Exotics. The preferred interpretation from the

1147 United Nations (1979) report is that these exotics are a tectonic window into units underlying

1148 the Pane Chaung Formation. This interpretation would require the following stages of

1149 development: 1) deformation and metamorphism of the Kanpetlet Schists and Pane Chaung

1150 Formation prior to deposition of the Paung Chaung Formation. 2) Deposition of the Paung

1151 Chaung Formation. 3) Thrusting of the Kanpetlet Schists, Pane Chaung, and Paung Chaung

1152 Formation. 4) Erosion of the thrust sheet and deposition of the Kabaw Formation.

A number of outliers of folded and faulted molasses deposits of probable late

Palaeogene age are preserved around peaks (Mol Lem, Phokphur, Kennedy) within the

Oligocene Pondaung-Tonhe Formation lies with a clear angular unconformity on the Naga

Metamorphic complex (Bannert et al., 2011). While in the Naga Ranges the Jopi/Phokphur

Formation is a shallow marine, $\sim 1000 \mathrm{~m}$ thick, molasse deposit that contains immature, polymictic clasts primarily derived from ophiolite, with some interbedded tuffaceous shales ophiolites within the Inner Belt.

Figure A1. Map of the Sin Chaung Exotics area showing the key region of the unconformity at the base of the Paung Chaung Formation. Modified from United Nations (1979b). 
Figure A2. Geological map of the northern Indo-Burma Ranges and Jade mines area. Inset shows localities of Orbitolina Limestones lying close to metamorphics in unconformable relationship. Partly based on maps in Mitchell (2017), and Thet Tin Nyung et al., (2017).

\section{Appendix 2 : Regional crust thickness map}

Regional variations in crust thickness are shown in Figure A3. The thickness variations of the section below low-velocity sedimentary units are plotted from summaries of shear wave velocity data from broadband seismic networks presented in Wang et al. (2019). This paper while containing the crustal thickness data, does not present a crustal thickness map. In Figure A3 the data from Wang et al. (2019) is supplemented by a similar study using broadband seismic networks from the Shillong-Mikir Hills Plateau by Bora and Baruah (2012). The crustal thickness map is not continued into the western Indo-Burma Ranges because this is the region where the crust of the Indo-Burma Ranges is overthrusting oceanic crust, hence the significance of crustal thickness variations becomes confused in this zone.

The data shows that areas of relatively thick crust are present in the Shan Plateau (i.e.

Western Sundaland) area, Shillong Plateau (Indian Continental crust) and also the core area (area A in Fig. A3) of the Indo-Burma Ranges. While thinner crust is present in the West Burma Terrane, and this crust becomes thinner passing towards the south. The crustal thickness map is helpful for corroborating interpretations associated with two key issues for plate reconstructions: 1) the eastern margin of the West Burma Terrane, and 2) whether a Mount Victoria Land micro-continent can be demonstrated.

The Sagaing Fault approximately follows the boundary of thin crust (West Burma Terrane) to the west and thicker crust (Shan Plateau/Sundaland) to the east. In the north the Sagaing Fault trends through thick crust, suggesting the young trace of the fault may have deviated from the West Burma Terrane/Sundaland boundary, to follow a NNE-SSW 
orientation. Perhaps the terrane boundary, together with an inactive transcurrent fault, trends NNW-SSE in the north (following the crustal thickness contours).

The thick crust in the inner Indo-Burma Ranges (location A in Figure A3) may just mark thickened crust related to an accretionary prism setting (Fig. 4). However, the presence of this belt of thick crust can also be invoked to support the presence of crust related to the Mt. Victoria Land micro-plate. However, this would be a narrow, thin sliver of crust,

Figure A3. Thickness of the crust from the base of the upper low velocity sedimentary section, to the Moho, based on broadband seismic data in Wang et al. (2019) supplemented by data from the Shillong Plateau area by Bora and Baruah (2012). Numbers 16, 17 and 20 denote spot crustal thickness in kilometres in areas that have not been contoured.

\section{FIGURES}

Figure 1. Regional map of the Indo-Burma Ranges. Inset map digital elevation model for Asia, B = Brahui Ranges, IBR = Indo-Burma Ranges, IYS = Indus-Yarlung Suture Zone (dashed blue line), $\mathrm{K}=$ Kirthar Ranges, $\mathrm{M}=$ Makran, $\mathrm{S}=$ Sulaiman Ranges, $\mathrm{SF}=$ Sagaing Fault.

Figure 2. Geological map of the Southern Chin Hills, modified from United Nations (1979a) and Mitchell et al. (2010). See Fig. 1 for location.

Figure 3. Geological map of the northern Chin Hills, Kalemyo area, modified from Mitchell et al. (2010). $\mathrm{X}=$ ophiolite-derived clasts and grains in Kabaw Formation sandstones (Fig. 20F). See Fig. 1 for location.

Figure 4. Semi-schematic cross-section across the Indo-Burma Ranges. Outer Belt detachment based on Betka et al. 2018, and Maurin and Rangin, (2009). Model for core of the 
accretionary prism modified from Harlow et al. (2014). Being semi-schematic there is no precise location for the cross-section, but the approximate location would run from the Bengal Trough onshore Bangladesh, across to the Kalemyo area, and across the Chindwin Basin.

Figure 5. Mélange associated with the ophiolites bodies. A) Satellite image of the Yazagyo Dam area, where ophiolitic mélange and a peridotite body are thrust over poorly exposed Triassic sandstones and mudstone. U-Pb zircon ages for gabbros and rodingites within this peridiote body have yielded ages between $133 \pm 2 \mathrm{Ma}$ and $126 \pm 2 \mathrm{Ma}$ (Liu et al., 2016a; Zhang J. et al., 2018), while radiolarians from the red bedded cherts of the isolated hill are of Middle Jurassic age (Zhang, J. et al., 2018). B) View to the NE showing the mélange of the spillway section. Examples of the blocks within the mélange are shown in C (bedded cherts), D (sheared basalts), and E (red cherts and various other blocks in sheared basalt matrix). F) Mélange of sheared mudstones and sandstones below the Webula Bula peridodite. See Fig. 3 for location.

Figure 6. View to the south of the Khwekha ophiolite forming the high ground overlying its metamorphic sole. U-Pb dating of zircons from amphibolites of the metamorphic sole indicate the age of metamorphism at $119 \pm 3 \mathrm{Ma}$, which is interpreted to represent the age of ophiolite emplacement (Zhang et al., 2017).

Figure 7. Calculation of the dip of the base of massive peridotite bodies from its intersection with stratigraphic contours, Kalemyo area. A) Webula Bula, dip 10.5, B) Bhopi Vun, dip $13.5^{\circ}$, C) Mwe Taung, dip 34․ See Fig. 3 for locations.

Figure 8. Outcrop examples of deformation in Kanpetlet Schists. A) River section at Chi Chaung Bridge south of Mindat. (21 21'18’N, 93,56', 15’E). B) Crenulated foliations with 
sub-horizontal axial surface, on steeply dipping foliations. C) Possibly the outcrop in A) is part of a NNW closing sheath fold (following the model of Maurin and Rangin, 2009 for the area). D. Example of shear sense indicators within the Kanpetlet Schists. $\mathrm{X}=$ boudinaged quartz vein with a delta clast geometry. $\mathrm{Y}=$ small isoclinal fold. Saw River. E. Example of plunging crenulation fold hinges on low-angled foliation.

Figure 9. Examples of the Kanpetlet Schists from the Saw River section, S. Chin Hills. a) Outcrop photograph of minor folds (F2) in sericite schist, quartz veins lie parallel to schistosity. b) Partially recrystallized quartz grains surrounded by muscovite. c) Crenulated low-angle foliations. d) Quartz vein, with outer region mostly equant grains, and inner zone with strongly aligned grains related to ductile shearing. e) and f) schist sample in plane and cross polarised light respectively, with mica predominantly aligned along $\mathrm{C}$ trends, with minor crenulated mica schistoisty in the quartz-dominated regions. The examples indicate complex, multi-phase nature of deformation in the schists, and the potential and need for detailed future studies to properly date, and unravel their deformation history.

Figure 10. Stereonets showing structural orientation data for the Kanpetlet Schists, and Pane Chaung Formation from the Southern Chin Hills.

Figure 11. Sketches of new road sections through the Pane Chaung Formation on the road to Mindat. See Fig. 2 for location.

Figure 12. Examples of normal faults in the Pane Chaung Formation, Saw River. A) One fault shows normal sense of drag, while the eastern fault shows rotated, inverted hanging all. B) Small normal faults with 1-2 m offset. C) Detail of normal fault zone, showing broad, sheared zone, typical of weakly lithified rock, and small thrust faults suggesting the fault is inverted. 
Figure 13. Small eastward-vergent ramping thrust in Pane Chaung Formation. Two small, relatively old normal faults are truncated by the ramping thrust. Saw River section.

1263 Figure 14. Detail of Midat road section showing multiple phases of folding. $F 1=1^{\text {st }}$ fold 1264 phase, F2 = second fold phase, T1 = late thrusting event that cuts F1 and F2 folds. See Fig. 11 1265 for location.

1266 Figure 15. Detail of Midat road section showing multiple phases of folding. $\mathrm{F} 1=1^{\text {st }}$ fold 1267 phase, $\mathrm{F} 2=$ second fold phase, $\mathrm{T} 1=$ late thrusting event that cuts $\mathrm{F} 1$ and $\mathrm{F} 2$ folds. F3 = expected folds related to $\mathrm{T} 1$, but not seen in this section. $\mathrm{F} 4$ = fourth fold phase related to late strike-slip faults (SS1). See Fig. 11 for location.

Figure 16. Detail of Midat road section showing multiple phases of folding F1 $=1^{\text {st }}$ fold phase, $\mathrm{F} 2=$ second fold phase, $\mathrm{T} 1=1$ thrusting event that cuts $\mathrm{F} 1$ and F2 folds. F3 = folds related to $\mathrm{T} 1 . \mathrm{F} 4=$ fourth fold phase related to late strike-slip faults $(\mathrm{SS} 1) . \mathrm{T} 2=$ thrust possibly developed close to time of SS1. Thrust X is cut by later faults at points Y and Z. See Fig. 11 for location.

Figure 17. Summary of the timing of events that affect the Pane Chaung Formation at the outcrop scale. This is probably not an exhaustive summary, but provides an indication of the complexity present, and the evolution recumbent style folding, to west-verging steeper folds associated with thrusts, to east-verging steep faults associated with strike-slip faults with time.

Figure 18. Cross-section along the Kalemyo-Falam Road based on field observations. $Z=$ hypothetical strike-slip faults driving uplift of Pane Chaung Formation. Stereonets of bedding orientations for the different formations, showing that the Cretaceous and Triassic formations are more tightly folded than the Palaeogene (Chunsung Formation) section. See Figure 3 for location. Strike-slip faults trending around $330^{\circ}-340^{\circ}$ were observed affecting the Kennedy 
Peak Sandstone, and are shown schematically in the figure around location X to help minimise the westwards thickening of the Palaeogene section.

Figure 19. Example of deformation with the Pane Chaung Formation from the Kalemyostrike-section through road outcrop. The section is affected by late, steeply dipping, obliqueslip dextral (reverse) faults. C, D and E detailed photos of the sections. Red arrows highlight the location of faults.

View east along Nattaga Chaung showing large, isolated carbonate olistolith (probably Globigerina limestone) forming the hill top, within the Late Cretaceous Falam Formation. B) Smaller body of limestone (olistolith), compared with A) within Falam Formation, Nattaga

Chaung. C) Typical flysch deposits of Falam Formation along Kalemyo-Falam road. D)

Reddish, pelagic limestone is isolated block along Nattaga Chaugn, probably part of limestone in A. E) Eocene Kennedy Sandstone, at Kennedy Peak. F) Lithic sandstone at base 1300 of Kabaw Formation, rich in lithics derived from ophiolites, east of Kalemyo, (Fig. 3, location X). G) Palaeocene-Eocene Chunsung Formation, Falam-Kennedy Peak road.

Figure 21. Comparison of folds seen on satellite images from A) Makran, and B) Indo-Burma Ranges west of Gangaw (see Fig. 1 for location).

Figure 22. Oblique Google Earth images of A) Kalemyo area, (northern Chin Hills), and B) 
transition from the Central Basin deposits to the east, to the Core of the Indo-Burma Ranges to the west. In A) the two regions are separated by the flat lying region of the Kabaw Valley. It is uncertain whether this region is controlled by a major strike-slip fault. In B) the two regions are marked by a low-angled, east-dipping unconformable contact. Multiple unconformities are involved, in different places the Paung Chaung, Kabaw Formation or the Paunggyi Formation may lie unconformably on the Pane Chaung Formation.

Figure 23. Geological map showing the South Kabaw Fault, and how it dies out passing into the Saw area, where instead of a fault contact between the Central Basin and the Indo-Burma Ranges, there is an unconformity. Map partly based on United Nations (1979a,b), and partly on satellite image interpretation. See Fig. 1 for location.

Figure 24. Topographic profiles across the Indo-Burma Ranges, calculated from Aster GDEM data, 1 arc second. Red lines indicate average slope with dip in degrees.

Figure 25. Structural styles in the southern Indo-Burma Ranges. Sketches of seismic lines that illustrate the geology of the Indo-Burma Ranges north (A) and south (B) of latitude $19^{\circ} 30^{\prime}$ N. A) Shows a series of simple folds, and a late thin prograding sequence (redrawn from Jain et al., 2010), see Fig. 1 for location. B) Shows the Rakhine shelf sequence deformed by normal faults that were inverted. The steep shelf margin shows extensive slumping (redrawn from Cliff and Carter, 2016). The locations of two other published sections are shown (Off Ched and CGG3). C) Digital elevation model with a fault pattern from satellite images superimposed. D) Summary of structural zones in the Southern IndoBurma Ranges. The green faults are the same as in C) the coast line is not shown, in order to show the trends of bedding near the coast (black lines) from seismic data. Bedding very frequently trends NW-SW a characteristic not seen further north. The yellow area corresponds with the offshore shelf province of mixed extension and contraction (as shown in 
B). Between the eastern margin of the yellow province and the deepwater faults there is a narrow belt of accretionary prism-like folds and thrusts. However, there may also be a significant amount of strike-slip faulting as well, particularly along the NE-trending parts of the margin (Nielsen et al., 2004; Rangin, 2017). See Fig. 1 for location.

Figure 26. Details of the structure of the southern Indo-Burma Ranges from satellite data, that show how the interpretation in Fig. $25 \mathrm{C}$ and $\mathrm{D}$ was made for the onshore area. A) Example of a WNW-ESE trending fold in Cretaceous-Eocene deepwater sedimentary rocks, Maw Yon. This example demonstrates the high level of detail available for observing structural trends and style along the coastline. Such detail is not possible to see inland. B) Example of changing structural styles across the ranges. Near the coast there are a mixture of NW-SE and N-S trends, with a prominent, NW-SE trending fold present near the coast at Shwethaungyan. This is a rare example of a major fold visible on satellite images in the southern Indo-Burma Ranges, wavelength $\sim 5 \mathrm{~km}$. Passing eastwards structures and bedding tend to strike N-S to NNE-SSW. Some N-S to NNE-SSW trending, narrow, linear valleys are interpreted to have formed along important strike-slip faults. Satellite image, with $80 \%$ opacity draped over digital elevation model. See Fig. 25 for location.

Figure 27. Cross-section based on the cross-section by Maurin and Rangin (2009) modified to to show key variations in tectonic models proposed for the Indo-Burma Ranges (IBR) and their advantages and disadvantages. A) and A1) are based on the ophiolites representing the Tethys suture, with Indian Plate, with obduction onto the India Plate occurring in the Maastrictian and an Indian Plate origin for the Pane Chaung Formation. A) is from Rangin et al. (2013), while A1) more explicitly shows the location of the main ophiolite body (Rangin, 2018). B) A model in many ways similar to A) except that a key phase of obduction is around 120-115 Ma (evidence from metamorphic sole in Kalemyo area, Zhang et al., 2018; and Albian-Cenomanian unconformity, United Nations, 1979). Collision with an Indian-derived 
crustal fragment (Mt Victoria Land, carrying Pane Chaung Formation) is a key feature (see Fig. 29). The problem with this model is that the crustal fragment involved would have to be, very thin, narrow crust, because there is not room in the IBR to fit a large crustal fragment.

C) A model to match the key evidence used in B), but without the need for Mt Victoria Land. This model is explained in detail in Figure 31. The model is based on accretionary-type ophiolite emplacement.

D) Accretionary model proposed by Zhang et al. (2018), where successive accretionary prisms have built out during the Jurassic-Palaeogene from the Sibumasu margin. A key problem with this model is that it does not match the palaeomagnetic data for the West Burma Terrane (Westerweel et al., 2019), and it does not explain why Pane Chaung Formation provenance (Sevastjanova et al., 2016) is so different from that of Sibumasuderived Late Triassic deepwater deposits on the western margin of the Shan Plateau (Cai et al., 2017).

Figure 28. Summary chart showing timing of key events in the development of the IndoBurma Ranges. Irr. Fm = Irrawaddy Formation, LNS/PKO = Letkat,Natma, Shwetamin formations (Chindwin Basin), or Pyawbwe, Kyaukkok and Obogon formations, (Minbu Basin), $\mathrm{CW}=, \mathrm{TTPY}=$ Tilin, Tabyin, Pondaung and Yaw formations, Lau. Fm $=$ Laungshe Formation, Paun. Fm. = Paunggyi Formation.

Figure 29. G-Plates model for the Early Cretaceous development of the West Burma Terrane modified from Zahirovic et al. (2016) and Westerweel et al. (2019). The model is based on the following assumptions/observations: 1) the Pane Chaung Formation was deposited on the Indian continent part of Gondwana, 2) the Aptian-Cenomanian limestone defines the oldest time Pane Chaung Formation was unconformably overlain by sediment deposited on the 
West Burma Terrane, 3) Ophiolites were thrust over the Pane Chaung Formation prior to deposition of the Aptian-Cenomanian limestone. $\mathrm{KA}=$ Kohistan Arc, GI = Greater India. Around 115 Ma a sliver of continent bearing the Pane Chaung Formation, called Mt Victoria Land approaches West Burma, and undergoes emplacement of ophiolites. By $95 \mathrm{Ma}, \mathrm{Mt}$ Victoria Land has collided with West Burma, and the ophiolites are unconformably overlain by Aptian-Cenomanian Limestones.

Figure 30. Model to explain the development of the Indo-Burma Ranges (IBR) as an early stage (Jurassic-Late Cretaceous) accretionary prism (with accretionary-type ophiolites), that evolved into a late-stage transpressional orogenic belt (Eocene-Recent), constrained by 1) the palaeo-locations of India (constrained by moving hotspot reference frame, O'Neill et al., 2005), and the West Burma Terrane (Westerweel et al., 2019), 2) the provenance of the Pane Chaung Formation, and 3) the timing of tectonic events summarised in Fig. 28. Accretionarytype ophiolites for the IBR have been proposed by several authors (Harlow et al., 2014; Fareeduddin and Dilek, 2015; Hla Htay et al., 2017; Barber et al., 2017; Zhang et al., 2018). In order to get the Pane Chaung Formation involved in the accretionary prism, the West Burma Block would have to be part of the rift system with India in which the Pane Chaung Formation- Langjiexue Group were deposited (A). Rifting of the West Burma Block left Pane Chaung Formation on both oceanic crust and continental crust, and when subduction of oceanic crust was initiated (perhaps following the process suggested by Hall, 2018), part of the Pane Chaung Formation was metamorphosed in the accretionary prism, and subduction channel to the Kanpetlet Schist, B) accretionary-type ophiolites emplaced around $115 \mathrm{Ma}$ (Zhang et al., 2018), or at least prior to deposition of Albian-Cenomanian limestone (United Nations, 1979). C) Deposition of Albian-Cenomanian limestone, Paung Chaung Formation (United Nations, 1979; Mitchell et al., 2010). This deposition is coincident with a spike in 
activity in the Wunto-Popa arc (Gardiner et al., 2015, 2018; Mitchell, 2018, hence perhaps uplift, and deposition of the Paung Chaung Formation was related to magmatic underplating and related uplift. D) Late Cretaceous, the Falam Formation contains extensive limestone blocks, which might be related to subduction of ocean island-type crust with seamounts (see Sengupta et al., 1989 for such an interpretation for the Disang Formation). Some trigger for the Kabaw Formation unconformity is required, and it is suggested that either subduction of thickened oceanic crust, or a slab window could be responsible. E) Transition period from subduction to coupling with Indian plate, including $60^{\circ}$ clockwise rotation of the West Burma Terrane (Westerweel et al, 2019). F) Coupling of the West Burma Terrane, with the thinned continental crust of northeastern India during the Late Eocene. Deposition in the Central Basin forearc basin (CB-FA) has begun. Start of predominantly strike-slip convergence with Sundaland. G) Late Miocene, West Burma is caught between two dextral strike-slip systems as the Burma Platelet (Rangin et al, 2013) one in the IBR, the other is the Sagaing Fault. Deposition in the Central Basin forearc and back-arc (CB-BA) is underway.

Figure 31. Plate tectonic setting for the Indo-Burma Ranges and West Burma Block (WB) in the Late Palaeogene (at $40 \mathrm{Ma}$ and $25 \mathrm{Ma}$ ), modified from Hall (2012), based on Late Eocene palaeomagnetic data in Westerweel et al., (2019). WAS = West Andaman Sea, EAS = East Andaman Sea. SP $=$ Shan Plateau, SCS $=$ South China Sea oceanic crust.

Table 1. Summary of published data on ophiolite formation and emplacement. Note the Jade Belt ages based on zircons are likely to be meaningless in terms of dating jade formation, because the zircons are rare in peridotite and are likely to be inherited, although exceptions 
can occur (e.g. kimberlites, crustal melts intruding into overlying mantle wedge above a slab, Hoskin and Schaltegger, 2003; Faithful et al., 2018).

Table 2 Summary of published tectonic models for the Pane Chaung Formation.

\section{REFERENCES}

Acharyya, S.K., 2007. Collisional emplacement history of the Naga-Andaman ophiolites and the position of the eastern Indian suture. Journal of Asian Earth Sciences, 29, 229242.

Advokaat, E.L., Bongers, M.L.M., Rudyawan, A., BouDagher-Fadel, M.K., Langereis, C.G., van Hinsbergen, D.J.J., 2018. Early Cretaceous origin of the Woyla Arc (Sumatra, Indonesia) on the Australian plate. Earth and Planetary Science Letters, 498, 348361.

Agiboust, S. and Agard, P., 2010. Initial water budget, the key to detaching large volumes of eclogitized oceanic crust along the subduction channel? Lithos, 120, 453-474.

Aitchison, J.C., Ao, A., Bhowmik, S., Clarke, G.L., Ireland, T.R., Kachovich, S., Lokho, K., Stojanovic, D., Roeder, T., Truscott, N., Zhen, Y. and Zhou, R., 2019. Tectonic evolution of the western margin of the Burma microplate based on new fossil and radiometric age constraints. Tectonics, 38, 1718-1741.

Allen , R., Najman, Y., Carter, A., Barfod, D., Bickle, M.J., Chapman, H.J., Garzanti, E., Vezzoli, G., Ando, S. and Parrish, R.R., 2008. Provenance of the Tertiary sedimentary rocks of the Indo-Burman Ranges, Burma (Myanmar): Burman arc or Himalayan-derived? Journal of the Geological Society, London, 165, 1045-1057.

Back, S., and Morley, C.K., 2016. Growth faults above shale - Seismic-scale outcrop analogues from the Makran foreland, SW Pakistan. Marine and Petroleum Geology, $70,144-162$.

Bannert, D., Lyen, A.S., and Htay, T., 2011. The Geology of Indoburman Ranges in Myanmar. Geologisches Jahrburch Reihe B, Heft, 101, Hannover. 
1457 Barber, A.J., and Crow, M.J., 2009. Structure of Sumatra and its implications for the tectonic 1458 assembly of Southeast Asia and the destruction of Paleothethys. Island Arc, 18, 3-

1459 20.

1460 Barber, A.J., Khin Zaw, and Crow, M.J., 2017. Chapter 31. The pre-Cenozoic tectonic 1461 evolution of Myanmar. In: Barber, A.J., Khin Zaw, and Crow, M.J. (eds.),

1462 Myanmar: Geology, Resources and Tectonics, Geological Society of London,

1463 Memoirs, 48, 687-712.

1464 
Barnes, P.M., Lamarche, G., Bialas, J., Henrys, S., Pecher, I., Greinert, J., Mountjoy, J.J., Pedley, K., Crutchely, G., 2010. Tectonic and geological framework for gas hydrates and cold seeps on the Hikurang subduction margin, New Zealand. Marine Geology, $272,26-48$.

Baxter, A.T., Aitchison, J.C., Zyabrev, S.V., and Ali, J.R., 2011. Upper Jurassic radiolarians from the Naga Ophiolite, Nagaland, northeast India. Gondwana Research, 20, 638644.

Betka, P.M., Seeber, L., Thomson, S.N., Steckler, M.S., Sincavage, R. and Vz, Z. 2018. Slippartitioning above a shallow, weak decollement beneath the IndoBurman accretionary prism. Earth Planetary Science Letters, 503, 17-28.

Bora, D.K., and Baruah, S., 2012. Mapping the crustal thickness in Shillong-Mikir Hills Plateau and its adjoining region of northeastern India using Moho reflected waves. Journal of Asian Earth Sciences, 48, 83-92.

Brunnschweiler, R.O., 1966. On the geology of the Indoburman Ranges. Journal of the Geological Society of Australia, 13, 137-194.

Brunnschweiler, R.O., 1974. Indoburman Ranges. In: Spencer, A.M. (ed.), MesozoicCenozoic Orogenic Belts: Data for Orogenic Studies. Geological Society of London Special Publication, 4, 279-299.

Burg, J.-P., 2018. Geology of the onshore Makran accretionary wedge: Synthesis and tectonic interpretation. Earth Science Reviews, 185, 1210-1231.

Cai, F., Ding, L., Yao, W., Laskowski, A.K., Xu, Q., Zhang, J., and Sein, K., 2016. Provenance and tectonic evolution of Lower Paleozoic-Upper Mesozoic strata from Sibumasu terrane, Myanmar. Gondwana Research, 41, 325-336.

Chatterjee, N., and Ghose, N.C., 2010. Metamorphic evolution of the Naga Hills eclogite and blueschist, Northeast India: implications for early subduction of the Indian plate under the Burman microplate. Journal of Metamorphic Geology, 28, 209-225. 
Chattopadhyaya, B., Venkataramana, P., Roy, D.K., Bhattacharyya, S. and Ghosh, S., 1983. Geology of the Naga Hills Ophiolites. Geological Survey of India, 112, 59-115.

Chhibber, H. L., 1927. The serpentines and associated minerals of the Henzada and Bassein Districts, Burma. Journal of the Burma Research Society, 16, 195-196.

Chhibber, H.L., 1934. Geology of Burma. London, Macmillan, 538p.

Chit Saing, 2000. Cretaceous events in Myanmar with special reference to foraminiferal evidence (abstract). IGCP434, Second International Symposium in Myanmar, December 10-11. 15-16.

Clegg, E.L.G., 1937. Notes on the geology of the Second Defile of the Irrawaddy River. Rec. Geol. Surv. India, 71, 350-359.

Clegg, E.L.G., 1941. The Cretaceous and associated rocks of Burma. Mem. Geol. Surv. India, $74,101 p$.

Cliff, D. and Carter, P., 2016. Exploration of the Rakhine Basin, pushing out the barriers with new 3D. AAPG Search and Discovery Article 10848, 25 pp.

Cotter, G. de P., 1938. The geology of parts of the Minbu, Myingyan, Pakkoku and Lower Chinwin districts, Burma. Geological Survey of India Memoir, 72, 2-136.

Curray, J.R., 2005. Tectonics and history of the Andaman Sea region. Journal of Asian Earth Sciences, 25, 187-228.

Dahlen, F. A. (1984), Noncohesive Critical Coulomb Wedges: An Exact Solution, Journal of Geophysical Research, 89(B12), 10125-10133.

Dahlen, F. A. (1990), Critical Taper Model of Fold-and-Thrust Belts and Accretionary Wedges, Annu Rev Earth P1 Sc, 18, 55-99.

Dahlen, F. A., J. Suppe, and D. Davis (1984), Mechanics of Fold-and-Thrust Belts and Accretionary Wedges: Cohesive Coulomb Theory, Journal of Geophysical Research, 89(B12), 10087-10101. 
Davis, D., Suppe, J. and Dahlen, F.A., 1983. Mechanics of fold-and-thrust belts and accretionary wedges. Journal of Geophysical Research, Solid Earth, 88, 1153-1172.

Faithfull, J.W., Dempster, T.J., MacDonald, J.M., and Reilly, M., 2018. Metasomatism and the crystallization of zircon megacrysts in Archean peridotites from the Lewisian complex, NW Scotland. Contributions to Mineralogy and Petrology, 173, doi: 10.1007/s00410-018-1527-5.

Fareeduddin and Dilek, Y., 2015. Structure and petrology of the Nagaland-Manipur Hill ophiolitic mélange zone, NE India: A fossil Tethyan subduction channel at the IndiaBurma plate boundary. Episodes, December, 298-314.

Gani, M.R., and Alam, M.M., 1999. Trench-slope controlled deep-sea clastics in the exposed lower Surma group in the southeastern fold belt of the Bengal Basin, Bangladesh. Sedimentary Geology, 127, 221-236.

Gardiner, N.J., Searle, M.P., Robb, L.J., and Morley, C.K., Kirkland, C.L., and Spencer, C.J., 2018. The crustal architecture of Myanmar imaged through zircon U-Pb, Lu-Hf and O isotopes: Tectonics and metallogenic implications. Gondwana Research, 62, 2760.

Gardiner, N.J., Searle, M.P., Morley, C.K., 2015. Neo-Tethyan magmatism and metallogeny in Myanmar - An Andean Analogue? Journal of Asian Earth Sciences, 106, 197215.

Ghose, N.C. and Singh, R.N., 1981. Structure of the Naga Hills ophiolite and associated sedimentary rocks in the Tuensang district of Nagaland, NE India. Ophioliti, 6, 237254.

Ghose, N.C., Agrawal, O. P. and Chatterjee, J., 2010. Geological and mineralogical study of eclogite and glaucophane schists in the Naga Hills ophiolite, Northeast India. Island Arc, 19, 336-356.

Ghose, N.C., Chatterjje, N., and Fareeduddin, 2014. A petrographic atlas of ophiolite: An example from the eastern India-Asia Collision Zone. Springer, 234 pp.

Gramman, F., 1974. Some palaeontological data on the Triassic and Cretaceous of the western part of Burma (Arakan Islands, Arakan Yoma, western outcrops of Central Basin). Newsletter Stratigraphy, 3, 272-290. 
Graveleau, F., Malavieille, J., and Dominguez, S., 2012. Experimental modelling of orogenic wedges: A review. Tectonophysics, 538-540, 1-66.

Hall, R., 2018. The subduction initiation stage of the Wilson cycle. Geological Society of London Special Publications, 470, doi: 10.1144/SP470.3

Hansen, L.D., Anderson, R.G., Dipple, G.M. and Nakano, K., 2004. Geological setting of listwanite (carbonated serpentinite) at Atlin, British Columbia: implications for $\mathrm{CO} 2$ sequestration and lode-gold mineralization. Geological Survey of Canada, Current Research, 2004-A5, 12 pp.

Harlow, G.E., Tsujimori, T. and Sorensen, S.S., 2014. Jadeitites and Plate Tectonics. Annual Review of Earth and Planetary Sciences, July, 105-138 Doi: 10.146/annurev-earth060614-105215;

Harris, R.A., 1992. Peri-collisional extension and the formation of Oman-type ophiolites in the Brooks Range and Banda arc. In: Parsons, L.M., Murton, B.J., and Browning, P. (eds.), Ophiolites and Their Modern Oceanic Analogues, Geological Society of London Special Publication, 60, 301-325.

Harris, R.A., 2003. Geodynamic patterns of ophiolites and marginal basins of the Indonesian and New Guinea regions. In: Dilek, Y., and Robinson, P.T. (eds.), Ophiolite in Earth History, Geological Society of London, Special Publication, 218, 481-505.

Hla Maung, 1987. Transcurrent movements in the Burma-Andaman Sea region. Geology, 15, 911-912.

Hla Htay, Khin Zaw and Than Than Oo, 2017. Chapter 6. The mafic-ultramafic (ophiolitic) rocks of Myanmar. In: Barber, A.J., Khin Zaw, and Crow, M.J. (eds.), Myanmar: Geology, Resources and Tectonics, Geological Society of London, Memoirs, 48, 117-141.

Hoskin, P.W.O., and Schaltegger, U., 2003. The composition of zircon and igneous and metamorphic petrogenesis. Reviews in Mineralogy and Geochemistry, 53, 27-62.

Ibotombi, S. and Singh, R.K.H., 2007. Chapter 15. Transtensional Basin in Oblique Subduction Margin: Imphal Valley, An Example. In: Sakalani, P.S. (ed.), Himalaya, Geological Aspects, Satish Serial Publishing House, New Delhi, 273-297. 
Jain, M., Das, P.S., Bandyopadhyay, B., 2010. Structural framework and deep-marine depositional environments of Miocene-Pleistocene sequence in western offshore Myanmar. $8^{\text {th }}$ Biennial International Conference and Exposition on Petroleum Geophysics, Hyderbad, India, p-58, 8 pp.

Kashkai, A.M., and Allakhverdiev, I., 1965. Listwanites: their origin and classification. Akad. Nauk AZSSR, Institute of Geology, Baku, Russia (in Russian).

Ki Khin, Khin Zaw and Lin Thu Aung, 2017. Chapter 4. Geological and tectonic evolution of the Indo-Myanmar Ranges (IMR) in the Myanmar region. In: Barber, A.J., Khin Zaw, and Crow, M.J. (eds.), Myanmar: Geology, Resources and Tectonics, Geological Society of London, Memoirs, 48, 65-79.

King, R.C. and Morley, C.K., 2017. Wedge geometry and detachment strength in deepwater fold-thrust belts. Earth-Science Reviews, 165, 268-279.

Kumar, A., Sanoujam, M., Sunil, L., and Dolendro, T., 2011. Active deformations at the Churachandpur Mao Fault (CMF), in Indo-Burma Ranges: Multidisciplinary Evidences. International Journal of Geosciences, 2, 597-609.

Kundu, B. and Gahalaut, V.K., 2013. Tectonic geodesy revealing geodynamic complexity of the Indo-Burmese arc region, North East India. Current Science, 104, 920-933.

Kyaw Linn Oo, Khin Zaw, Meffre, S., Myitta, Day Wa Aung, and Lai, C.-K., 2015, Provenance of the Eocene sandstones in the southern Chindwin Basin, Myanmar: Implications for the unroofing history of the Cretaceous-Eocene magmatic arc: Journal of Asian Earth Sciences, v. 107, 172-194.

Lepper, G.W., 1933. An outline of the geology of the oil-bearing regions of the ChindwinIrrawaddy valley of Burma and of Assam-Arakan. ${ }^{\text {st }}$ World Petroleum Congress, London, July 18-24, 1933, proceedings, 11 pp.

Li, X. P., Rahn, M., and Bucher, K., 2004. Serpentinites of the Zermatt-Saas ophiolite complex and their textural evolution. Journal of Geology, 22, 159-177. 
Licht, A., Dupont-Nivet, G., Zaw Win, Hnin Hnin Swe, Myat Kaythi, Roperch, P., Ugrai, T., Littell, V., Park, D., Westerweel, J., Jones, D., Poblete, F., Day Wa Aung, Huang, H., Hoorn, C., and Sein, K., 2018, Paleogene evolution of the Burmese forearc basin and implications for the history of India-Asia convergence: GSA Bulletin, doi.org/10.1130/B35002.1

Liu, C.-Z., Zhang, C., Xu, Y., Wang, J.-G., Chen, Y., Guo, S., Wu, F.-Y., and Sein, K., 2016a. Petrology and geochemistry of mantle peridotites from the Kalaymyo and Myitkyina ophiolites (Myanmar): Implications for tectonic settings. Lithos, 264, 495-508.

Liu, C.-Z., Chung, S.-L., Wu, F.-Y., Zhang, C., Xu, Y., Wang, J.-G., Chen, Y. and Guo, S., 2016b. Tethyan suturing in Southeast Asia: Zircon U-Pb and Hf-O isotopic constaints from Myanmar ophiolites. Geology, 44, 311-314.

Luschen, E., Muller, C., Kopp, H., Engles, M., Lutz, R., Planert, L., Shulgin, A., and Djajdihard, Y.S., 2011. Structure, evolution and tectonic activity of the eastern Sunda forearc, Indonesia, from marine seismic investigatins. Tectonophysics, 508, $6-21$.

Maurin, T. and Rangin, C., 2009. Structure and kinematics of the Indo-Burmese Wedge: recent and fast growth of the outer wedge. Tectonics, 28, TC20010.

Mitchell, A.H.G., 1981. Phanerozoic plate boundaries in mainland SE Asia, the Himalayas and Tibet. Journal of the Geological Society, London, 138, 109-122.

Mitchell, A.H.G., 1986. Mesozoic and Cenozoic regional tectonics and metallogenesis in mainland SE Asia. In: GEOSEA V Proceedings, II, Geological Society of Malaysia, Bulletin, 20, 221-239.

Mitchell, A.H.G., 1989. The Shan Plateau and western Burma: Mesozoic-Cenozoic plate boundaries and correlations with Tibet. In: Sengor, A.M.C. (ed.), Tectonic Evolution of the Tethyan Region, NATO Advanced Science Institute Series, 259, Kluwer Academic Publishers, 567-583.

Mitchell, A. H. G., 1993. Cretaceous - Cenozoic tectonic events in the western Myanmar (Burma) - Assam region. J. Geol. Soc. London, 150, 1089-1102. 
Mitchell, A.H.G., Tin Hlaing and Nyunt Htay, 2010. The Chin Hills Segment of the IndoBurman Ranges: Not a simple accretionary wedge. Memoir Geological Society of India, 3-24.

Mitchell, A. H. G., 2017. Geological Belts, Plate Boundaries and Mineral Deposits in Myanmar. Elsevier, Amsterdam, 524 pp.

Monie, P. and Agard, P., 2009. Coeval blueschist exhumation along thousands of kilometers: Implications for subduction channel processes. Geochemistry, Geophysics, Geosystems, 10., Q07002, doi: 10.1029/2009GC002428

Moore, G.F., Lin Thu Aung, Fukuchi, R., Sample, J.C., Hellebrand, E., Kopf, A., Win Naing, Wind Min Than, Tin Naing Tun. 2019. Tectonic, Diapiric and Sedimentary Chaotic Rocks of the Rakhine Coast, Western Myanmar. Gondwana Research, doi:10.1016/j.gr.2019.04.006.

Morley, C. K., 1988. Out of sequence thrusts. Tectonics, 7, 539-561.

Morley, C.K., 2007. Interaction between critical wedge geometry and sediment supply in a deep-water fold belt. Geology 35, 139-142.

Morley, C. K., 2009. Evolution from an oblique subduction back-arc mobile belt to a highly oblique collisional margin: the Cenozoic tectonic development of Thailand and eastern Myanmar. Geological Society of London Special Publications, 318, 373-403.

Morley, C.K., 2012. Late Cretaceous-early Palaeogene tectonic development of SE Asia. Earth-Science Reviews, 115, 37-75.

Morley, C.K., 2016. Syn-kinematic sedimentation at a releasing splay in the northern Minwun Ranges, Sagaing Fault zone, Myanmar: significance for fault timing and displacement. Basin Research, 29, 684-700.

Morley, C. K., 2017. Cenozoic rifting, passive margin development and strike-slip faulting in the Andaman Sea : A discussion of established v. new tectonic models. In: 
Bandopadhyay, P.C., and Carter A. (eds.), The Andaman-Nicobar Accretionary Ridge: Geology, Tectonics and Hazards, Geological Society, London, Memoir 47, 27-50.

Morley, C.K., Searle, M., 2017. Chapter 5. Regional tectonic, structure and evolution of the Andaman-Nicobar Islands from ophiolite formation and obduction to collision and back-arc spreading. In: Bandopadhyay, P.C., and Carter A. (eds.), The AndamanNicobar Accretionary Ridge: Geology, Tectonics and Hazards, Geological Society, London, Memoir 47, 51-74.

Morley, C. K. and Arboit, C., 2019. Dating the onset of motion on the Sagaing Fault: Evidence from detrital zircon and titanite $\mathrm{U}-\mathrm{Pb}$ geochronology from the North Minwun Basin, Myanmar. Geology, doi: 10.1130/G46321.1

Morley, C.K., von Hagke, C., Hansberry, R., Collins, A., W. Kanitpanyacharoen, King, R., 2018. Review of major shale-dominated detachment and thrust characteristics in the diagenetic zone: Part II, rock mechanics and microscopic scale. Earth-Science Reviews, 176, 19-50.

Ngaw Cin Pau, 1962. Report on a geological reconnaissance in the Naga Hills. Geological Section, Petroleum and Minerals Development Corporation, Government of Burma, Rangoon, 33pp.

Nielsen, C., Chamot-Rooke, N., Rangin, C., and The Andaman Cruise Team, 2004. From partial to full strain-partitioning along the Indo-Burmese hyper-oblique subduction. Marine Geology, 209, 303-327.

Noetling, F., 1901. The fauna of the Miocene beds of Burma. Geological Survey of India Memoirs, 1, 1-378.

O’Neill, C., Muller, D., Steinberger, B., 2005. Geodynamic implications of moving Indian Ocean hotspots. Earth and Planetary Science Letters, 215, 151-168. 
Pascoe, E.H., 1912. A traverse across the Naga Hills of Assam from Dimapur to the neighbourhood of Sarameti Peak. Geological Survey of India Records, 42, 254-264.

Pesicek, J.D., Thurber, C.H., Widiyantoro, S., Zhang, H., DeShon, H.R., and Engdahl, E.R., 2010. Sharpening the tomographic image of the subducting slab below Sumatra, the Andaman Islands and Burma. Geophysical Journal International, doi:10.111/j.1365246X.2010.04630.x

Qi, M. Xiang, H., Zhang, Z.Q.,2014. Zircon U-Pb ages of Myanmar jadeitite and constrain on the fluid in subduction zone of Neo-Tethys. Acta Petrol. Sinica, 20, 2279-2286 (in Chinese with English abstract).

Rangin, C., 2017. Chapter 3. Active and recent tectonics of the Burma Platelet in Myanmar. In: Barber, A.J., Khin Zaw and Crow, M.J. (eds.), Myanmar: Geology, Resources and Tectonics, Geological Society of London, Memoirs, 48, 53-64.

Rangin, C., 2018. The western Sunda Basins, and the India/Asia collision: An Atlas. Geotecto, Société Géologique de France, 294 pp.

Rangin, C., Maurin, T., and Masson, F., 2013. Combined effects of Eurasia/Sunda oblique convergence and East-Tibetan crustal flow on the active tectonics of Burma. Journal of Asian Earth Sciences, 76, 185-194.

Ridd, M.F., Crow, M. J., and Morley, C.K., 2019. The role of strike-slip faulting in the history of the Hukawng Block and the Jade Mines Uplift, Myanmar. Proceedings of the Geologists’ Association, Doi: 10.016/j.pegola.2019.01.002

Ruh, J.B., Le Pourhiet, L., Agard, Ph., Burov, E. and Gerya, T., 2015. Tectonic slicing of subducing oceanic crust along plate interfaces: Numerical modeling. Geochemistry, Geophysics, Geosystems, 16, 3505-3531. Saffer, D.M., Bekins, B.A., 2002. Hydrologic controls on the morphology and mechanics of accretionary wedges. Geology 30, 271-271.

Saffer, D.M., and Tobin, H.J., 2011. Hydrogeology and Mechanics of Subduction Zone Forearces: Fluid Flow and Pore Pressure. Annual Review Earth and Planetary Sciences, 39, 157-186. 
Sahni, M.R., 1937. Discovery of Orbitolina-bearing rocks in Burma. Rec. Geol. Surv. India, $71,360-375$.

Screaton, E., Kimura, G., Curewitz, D., Moore, G., Chester, F., Fabbri, O., Fergusson, C., Girault, F., Goldsby, D., Harris, R., Inagaki, F., Jiang, T., Kitamura, Y., Knuth, M., Li, C.-F., Claesson Liljedahl, L., Louis, L., Milliken, K., Nicholson, U., Riedinger, N., Sakaguchi, A., Solomon, E., Strasser, M., Su. X., Tsutsumi, A., Yamaguchi, A., Ujiee, K., Zhao, X., 2009. Interactions between deformation and fluids in the frontal thrust region of the NanTroSEIZE transect offshore the Kii Peninsula, Japan: Results from IODP Expedition 316 Sites C0006 and C0007. Geochem. Geophys. Geosys. 10, doi:10.1029/2009GC002713

Searle, M.P., Morley, C.K., Waters, D.J., Gardiner, N.J., U. Kyi Htun, Than Than Nu and Robb, N.J., 2017. Chapter 12, Tectonic and metamorphic evolution of the Mogok Metamorphic and Jade Belts, and ophiolitic terranes of Burma (Myanmar). In: Barber, A.J., Khin Zaw and Crow, M.J. (eds.), Myanmar: Geology, Resources and Tectonics, Geological Society, London, Memoirs, 48, 263-295.

Sengupta, S., Acharyya, S.K., Van Den Hul, H.J. and Chattopadhyay, B., 1989. Geochemistry of volcanic rocks from the Naga Hills Ophiolites, northeast India and their inferred tectonic setting. Journal of the Geological Society, London, 146, 491498.

Sevastjanova, I., Hall, R., Rittner, M., Paw, S.M.T.L., Tin Tin Naing, Alderton, D.H., Comfort, G., 2016. Myanmar and Asia united, Australia left behind long ago. Gondwana Research, 32, 24-40.

Sherlock, R.L., Logan, M.A.V., Jowett, E.C., 1993. Silica carbonate alteration of serpentinite, implications for the association of precious metal and mercury mineralization in the Coast Ranges. Society of Economic Geology Guidebook Series, 16, 90-116.

Shi, G., Grimaldi, D.A., Harlow, G.E., Wang, J., Wang, J., Yang, M., Lei, W., Li, Q. and Li, X., 2012. Age constraint on Burmese amber based on U-Pb dating of zircons. Cretaceous Research, 37, 155-163. 
Shi, G., Lei, W., He, H., Ng, Y.N., Liu, Y., Liu, Y., Yuan, Y., Kang, Z., and Xie. G., 2014. Superimposed tectono-metamorphic episodes of Jurassic and Eocene age in the jadeite uplift, Myanmar as revealed by ${ }^{40} \mathrm{Ar} /{ }^{39} \mathrm{Ar}$ dating. Gondwana Research, 26, 464-474.

Sibuet, J.-C., Klingelhoefer, F., Huang, Y.-P., Yeh, Y.-C., Rangin, C., Lee, C.-S. and Hsu, S.K., 2016. Thinned continental crust intruded by volcanics beneath the northern Bay of Bengal. Marine and Petroleum Geology, 77, 471-486.

Simpson, G.D.H., 2010. Formation of accretionary prisms influenced by sediment subduction and supplied by sediments from adjacent continents. Geology 38(2), 131- 134.

Singh, A.K., Khogenkumar, S., Singh, L.R., Bikramaditya, R.K., Khuman, C.M., and Thakur, S.S., 2016. Evidence of Mid-ocean ridge and shallow subduction forearc magmatism in the Nagaland-Manipur ophiolites, northeast India: constraints from mineralogy and geochemistry of gabbros and associated maffic dykes. Chemie der Erde Geochemistry, 76, 605-620.

Singh, A.K., Chung, S.-L., Bikramaditya, R.K. and Lee, H.Y., 2017. New U-Pb zircon ages of plagiogranites from the Nagaland-Manipur Ophiolites, Indo-Myanmar Orogenic Bel, NE India. Journal of the Geological Society, 174, 170-179.

Singh, R.N. and Ghose, N.C., 1982. Geology and Stratigraphy of the Ophiolite Belt of Naga Hills, East of Kiphire, NE India. Recent Researches in Geology (Delhi), 8, 359-381.

Sloan, R.A., Elliott, J.R., Searle, M.P. and Morley, C.K., 2017. Chapter 2. Active tectonics of Myamar and the Andaman Sea. In: Barber, A.J., Khin Zaw and Crow, M.J. (eds.), Myanmar: Geology, Resources and Tectonics, Geological Society of London, Memoirs, 48, 19-52.

Socquet, A., Goffe', B., Pubellier, M. and Rangin, C., 2002. Le metamorphisme TardiCretace a Ecoene des zones internes de la chaine Indo-Birmane (Burma occidental): implication geodynamique. Comptes Rendus, Geosciences, 334, 573-580. 
Srisuriyon, K. and Morley, C.K., 2014. Pull-apart development at overlapping fault tips: Oblique rifting of a Cenozoic continental margin, northern Mergui Basin, Andaman Sea. Geosphere, 10, 80-106.

Steckler, M.S., Mondal, D.R., Akhter, S.H., Seeber, L., Feng, L., Gale, J., Hill, E.M. and Howe, M., 2016a. Locked and loading metathrust linked to active subduction beneath the Indo-Burman Ranges. Nature Geoscience 9, 615-618.

Steckler, M.S., Mondal, D.R., Akhter, S.H., Seeber, L., Feng, L., Gale, J., Hill, E.M.,, and Howe, M., 2016b. Deformation and seismic hazard associated with the Indo-Burman foldbelt from new GPS measurements in Bangladesh. Nature Geosciences, doi: $10.1038 /$ ngeo 2760 .

Stork, A.L., Selby, N.D., Heyburn, R., and Searle, M.P., 2008. Accurate relative earthquake hyopcenters reveal structure of the Burma subduction zone. Bulletin of the Seismological Society of America, 98, 2815-2827.

Storti, F., McClay, K., 1995. Influence of syntectonic sedimentation on thrust wedges in analogue models. Geology 23(11), 999-1002.

Storti, F., Salvini, F. and McClay, K., 2000. Synchronous and velocity-partitioned thrusting and thrust polarity reversal in experimentally produced, doubly-vergent thrust wedges: implications for natural orogens. Tectonics, 19, 378-396.

Stuart, M., 1923. Geological traverses from Assam to Myitkyina, through the Hukong Valley: Myitkyina to northern Putao; and Myitkyina to the Chinese frontier. Geological Survey of India Records, 54, 398-411.

Suppe, J., 2007. Absolute fault and crustal strength from wedge tapers. Geology 35, $1127-$ 1130.

Than Tun, 1967. Geological report on part of Western Outcrops, Tilin-Pauk-Lyauktu areas, Pakokku District. People’s Oil Industry. Yangon, unpublished.

Theingi Kyaw, 2005. Foraminiferal biostratigraphy and palaeogeography of the Paunggyi Formation, Saw Township. PhD. Dissertation, Department of Geology, University of Yangon, Myanmar, 202 pp. 
Theobald, W., 1871. The axial group in Western Prome, British Burmah. Geological Survey of India Records (Calcutta), 4, 33-44.

Theobald, W., 1872. A few additional remarks on the axial group of Western Prome. Geological Survey of India Records (Calcutta), 5, 79-82.

Thet Tin Nyung, Massonne, H.-J., and Tay Thye Sun, 2017. Chapter 13, Jadeitite and other high-pressure metamorphic rocks from the Jade Mines Belt, Tawmaw area, Kachin State, northern Myanmar. In: Barber, A.J., Khin Zaw, and Crow, M.J. (eds.), Myanmar: Geology, Resources and Tectonics, Geological Society of London, Memoirs, 48, 297-317.

Thura Oo and Chit Saing, 2000. Brief account of the Cretaceous foraminiferal biostratigraphy of Myanmar (abstract). IGCP434, Second International Symposium in Myanmar, December 10-11. 20-21.

Ueno, K., Myint Thein, and Barber, A.J., 2016. Permian fusuline fauna from the Minwun Range, Central Myanmar (abstract). The $5^{\text {th }}$ International Symposium of the International Geoscience Programme (IGCP) Project 589. October 25-November 2, Yangon, Myanmar, 6.

United Nations, 1979a. Geology and Exploration Geochemistry of part of the Northern and Southern Chin Hills and Arakan Yoma, western Burma. Technical Report, 4, United Nations Development Programme, DP/UN/BUR-72-002/13, United Nations, New York, $59 \mathrm{pp}$.

United Nations, 1979b. Mineral exploration Burma, Geological mapping and geochemical exploration in Mansi-Manhton, Indaw-Tigyaing, Kyindwe-Longyi, Patchaung-Yane and Yezin areas, Burma. United Nations Development Programme, UN/BUR/72/002,16, report 7, United Nations, New York.

Van Hinsbergen, D. J.J., Steinberger, B., Doubrovine, P.V. and Gassmoller, R., 2011. Acceleration and deceleration of India-Asia convergence since the Cretaceous: Roles of mantle plumes and continental collision. Journal of Geophysical Research: Solid Earth, 116, doi: 10.1029/2010JB008051.

Vogt, K. and Gerya, T., 2014. Deep plate serpentinization triggers skinning of subducting slabs. Geology, 42, 723-726. 
Wakabayashi, J. 2017, Serpentinites and serpentinites: Variety of origins and emplacement mechanisms in the Californian Cordillera. Island arc, doi:10.111/iar.12205

Wang, W.H., and Davis, D.M., 1996. Sandbox model simulation of forearc evolution and noncritical wedges. Journal of Geophysical Research, 101, 11329-11340.

Wang, J.-G., Wu, F.-Y., Tan, X.-C., and Liu, C.-Z., 2014. Magmatic evolution of the Western Myanmar Arc documented by U-Pb and Hf isotopes in detrital zircon. Tectonophysics, 612-613, 97-105.

Wang, J.-G., Wu, F.-Y., Garzanti, E., Hu, X., Ji, W.-Q., Liu, Z.-C., Liu, X.-C., 2016. Upper Triassic turbidites of the northern Tethyan Himalaya (Langjiexue Group): The terminal of a sediment-routing system sourced in the Gondwanide Orogen. Gondwana Research, 34, 84-98.

Wang, Y., Sieh, K., Soe Thrua Tun, Lai, K.-Y., and Than Myint, 2014. Active tectonics and earthquake potential of the Myanmar region. Journal of Geophysical Research, Solid Earth, doi://10.1002/2013JB010762.

Wang, X., Wei, S., Wang, Y., Phyo Maung Maung, Hubbard, J., Banerjee, P., Huang, B.-S., Kyaw Moe Oo, Bodin, T., Foster, A. and Almeida, R., 2019. A 3-D shear wave velocity model for Myanmar Region. Journal of Geophysical Research: Solid Earth, 124, 504-526. Doi.org/10.1029/2018JB016622.

Westerweel, J., Roperch, P., Licht, A., Dupont-Nivet, G., Zaw Win, Poblete, F., Ruffet, G., Hnin Hnin Swe, Myat Kai Thi and Day Wa Aung, 2019. Burma Terrane part of the Trans-Tethyan arc during collision with India according to palaeomagnetic data. Nature Geoscience, doi: 10.1038/s41561-019-0443-2

Willet, S.D., Beaumont, C. and Fullsack, P., 1993. Mechanical model for the tectonics of doubly vergent compressional orogens. Geology, 21, 371-374.

Win Swe, Thacpaw, C., Nay Thaung Thaung, and Kyaw Nyunt, 1972. Geology of part of the Chindwin basin of the central belt Burma. Report, Department of Geology, Arts and Science University, Mandalay, 34pp.

Yadav, R. and Tiwari, V.M., 2018, in press. A three-dimensional density model of north Andaman subduction zone. Journal of Geodynamics.doi:org/10.1016/j.jog.2018.09.005 
Yao, W., Ding, L., Cai, F., Wang, H., Xu, Q., and Than Zaw. 2017, Origin and tectonic evolution of upper Triassic turbidites in the Indo-Burman ranges, West Myanmar. Tectonophysics, 721, 90-105.

Yui, T.-Z., Fukoyama, M., Lizuka, Y., Wu, C.-M., Wu, T.-W., Liou, J.G., Grove, M., 2013. Is Myanmar jadeitite of Jurassic age? A result from incompletely recrystallized inherited zircon. Lithos, 160-161, 268-282.

Zahirovic, S., Matthews, K.J., Flament, N., Muller, R.D., Hill, K.C., Seton, M., and Gurnis, M., 2016. Tectonic evolution and deep mantle structure of the eastern Tethys since the latest Jurassic. Earth-Science Reviews, 162, 293-337.

Zhang, J., Xiao, W., Windley, B.F., Cai, F., Sein, K. and Naing, S., 2017. Early Cretaceous wedge extrusion in the Indo-Burma Range accretionary complex: implications for the Mesozoic subduction of Neothethys in SE Asia. International Journal of Earth Science, Doi: 10.1007/s0053101714687.

Zhang, J., Xiao, W., Windley, B.F., Wakabayashi, J., Cai, F., Sein, K., Wu, H., Naing, S., 2018. Multiple alternating forearc- and backarc-ward migration of magmatism in the Indo-Myamar orogenic belt since the Jurassic: Documentation of the orogenic architecture of eastern Neotethys in SE Asia. Earth Science Reviews, 185, 704-731.

Zhang, X., Chung, S.-L., Lia, Y.-M., Ghani, A.A., Murtadha, S., Lee, H.-Y., and Hsu, C.-C., 2018. Detrital Zircons Dismember Sibumasu in East Gondwana. Journal of Geophysical Research, Solid Earth, 123, https://doi.org/10.1029/2018JB015780. 


\begin{tabular}{|c|c|c|c|c|c|c|}
\hline $\begin{array}{l}\text { Location of } \\
\text { ophiolite }\end{array}$ & $\begin{array}{l}\text { Dating of } \\
\text { ophiolite } \\
\text { formation }\end{array}$ & Environment & $\begin{array}{l}\text { Presence of } \\
\text { HP-LT } \\
\text { Metamorphism }\end{array}$ & $\begin{array}{l}\text { Dating of } \\
\text { ophiolite } \\
\text { emplacement } \\
\text { within wedge }\end{array}$ & $\begin{array}{l}\text { Dating of } \\
\text { ophiolite } \\
\text { exhumation }\end{array}$ & Dating of metamorphism \\
\hline Naga-Manipur & $\begin{array}{l}\text { 116.4 } \pm 2.2 \mathrm{Ma} \text {, } \\
118 \pm 1.2 \mathrm{Ma} \text {, } \\
\text { U-Pb } \\
\text { Plagiogranite } \\
\text { Singh et al. } \\
\text { (2017), } \\
\text { Aitchison et } \\
\text { al., (2019) }\end{array}$ & $\begin{array}{l}\text { Both MOR } \\
\text { and supra- } \\
\text { subduction } \\
\text { zone (Singh et } \\
\text { al., 2016) }\end{array}$ & $\begin{array}{l}\text { Eclogites and } \\
\text { blueschists } \\
\text { (Ghose et al., } \\
\text { 2010) }\end{array}$ & $\begin{array}{l}\text { Pre-Late } \\
\text { Eocene }\end{array}$ & Pre-Late Eocene & Pre-Late Eocene \\
\hline Jade Belt & $\begin{array}{l}\text { Yui et al., } \\
2013) . \\
\text { Speculated } \\
\text { oldest zircon } \\
\text { ages = time of } \\
\text { oceanic crust } \\
\text { formation = } \\
160 \pm 1 \mathrm{Ma} \text {, } \\
159 \pm 1 \mathrm{Ma} .\end{array}$ & & $\begin{array}{l}\text { Jadeitite, } \\
\text { glaucophane } \\
\text { schist (Shi et al., } \\
\text { 2001; Thet Tin } \\
\text { Nyunt, 2009; } \\
\text { Thet Tin Nyunt } \\
\text { et al., 2017) }\end{array}$ & $\begin{array}{l}\text { Pre- } \\
\text { Cenomanian } \\
\text { (Appendix 1)- } \\
98.8 \mathrm{Ma} \text { (Shi et } \\
\text { al., 2012) } \\
\text { unconformity. } \\
\text { Ar/Ar ages } \\
152.4 \pm 1.5 \mathrm{Ma} \\
\text { (Shi et al., } \\
\text { 2014), 147, Qi } \\
\text { et al. (2014) }\end{array}$ & $\begin{array}{l}1^{\text {st }} \text { exhumation } \\
\text { pre Cenomanian } \\
\text { unconformity. } \\
2^{\text {nd }} \text { Exhumation } \\
\text { by strike-slip } \\
\text { activity }\end{array}$ & $\begin{array}{l}\text { U-Pb zircon of from } \\
\text { jadeitite, of } \\
\text { metasomatic/hydrothermal } \\
\text { Origin, } 77 \pm 3 \text { Ma minimum } \\
\text { age (Yui et al., 2013). } \\
\text { Ar/Ar ages } 152.4 \pm 1.5 \mathrm{Ma} \\
\text { (Shi et al., 2014), 147, Qi et } \\
\text { al. (2014) }\end{array}$ \\
\hline $\begin{array}{l}\text { Kalemyo } \\
\text { region }\end{array}$ & $\begin{array}{l}\text { Rodingite, U- } \\
\mathrm{Pb} 126.6 \pm 1,0 \\
\mathrm{Ma}, 126.6 \pm 1,0 \\
\mathrm{Ma}, 125.8 \pm 11.7 \\
\text { Ma (Liu et al., } \\
\text { 2016b). } \\
\text { Gabbro 133 } \pm \\
2,131 \pm 2 \text { Ma, } \\
\text { Zhang et al. } \\
\text { (2018) }\end{array}$ & $\begin{array}{l}\text { MOR, Liu et } \\
\text { al. (2016a) }\end{array}$ & No & $\begin{array}{l}\text { Amphibolite } \\
\text { (metamorphic } \\
\text { sole) U-Pb, } \\
114.7 \pm 1.4 \\
\text { Ma, Liu et al. } \\
\text { (2016b), } \\
119.07 \pm 3 \mathrm{Ma} \text {, } \\
\text { Zhang et al. } \\
\text { (2017) }\end{array}$ & $\begin{array}{l}\text { Prior to } \\
\text { Campanian- } \\
\text { Maastrichtian - } \\
\text { Kabaw Fm. } \\
\text { (Appendix 1) }\end{array}$ & \\
\hline Chin Hills & $\begin{array}{l}158 \pm 20 \mathrm{Ma}, \\
\mathrm{K}-\mathrm{Ar}, \\
\text { hornblende, } \\
\text { Michell (1981) }\end{array}$ & & $\begin{array}{l}\text { ? Borderline } \\
\text { greenschist/HP } \\
\text { facies reported } \\
\text { by Socquet et al. } \\
\text { (2002) } \\
\end{array}$ & $\begin{array}{l}\text { Pre-Late } \\
\text { Albian- } \\
\text { Cenomania } \\
\text { (Appendix 1) }\end{array}$ & $\begin{array}{l}\text { Campanian- } \\
\text { Maastrichtian- } \\
\text { Kabaw Fm. } \\
\text { (Appendix } 1\end{array}$ & $\begin{array}{l}\text { Kanpetlet Schist, Pre } \\
\text { Campanian-Maastricthian. } \\
\text { United Nations (1979) }\end{array}$ \\
\hline Mindon & None & & No & & $\begin{array}{l}\text { Pre-Upper } \\
\text { Maastrictian } \\
\text { (Paunggyi/Kabaw } \\
\text { Formation, } \\
\text { Bannert et al., } \\
\text { 2011) } \\
\end{array}$ & \\
\hline $\begin{array}{l}\text { Naga } \\
\text { Metamorphics }\end{array}$ & None & & $\begin{array}{l}\text { Glaucophane } \\
\text { schist (Bannert } \\
\text { et al., 2011) }\end{array}$ & & & $\begin{array}{l}\text { Pre-Early Oligocene } \\
\text { (Bannert et al., 2011). } \\
\text { Protolith - Palaeozoic- } \\
\text { Triassic? Ordovician age } \\
\text { protolith (Aitchison et al., } \\
\text { 2019). }\end{array}$ \\
\hline
\end{tabular}




\begin{tabular}{|c|c|c|c|c|}
\hline $\begin{array}{l}\text { Depositional } \\
\text { location }\end{array}$ & Advantage & Arguments against & $\begin{array}{l}\text { Position } \\
\text { with } \\
\text { respect to } \\
\text { IBR }\end{array}$ & References \\
\hline $\begin{array}{l}\text { 1) Western } \\
\text { Margin of } \\
\text { Sibumasu. } \\
\text { Fig. 27D. }\end{array}$ & $\begin{array}{l}\text { Simplest } \\
\text { interpretation. } \\
\text { Eliminates need for } \\
\text { West Burma Block }\end{array}$ & $\begin{array}{l}\text { Ignores presence of Triassic } \\
\text { turbidites of Shweminbon Formation } \\
\text { on margin of Shan Plateau, with } \\
\text { significantly different provenance } \\
\text { (see section 7). Palaeomagnetic data } \\
\text { in favour of West Burma Block } \\
\text { (Westerweel et al., 2019) }\end{array}$ & $\begin{array}{l}\text { Passive } \\
\text { margin } \\
\text { deposits, } \\
\text { predominan } \\
\text { tly in upper } \\
\text { plate of } \\
\text { subduction } \\
\text { zone. }\end{array}$ & $\begin{array}{l}\text { Zhang, J. et al. } \\
\text { (2018). }\end{array}$ \\
\hline $\begin{array}{l}\text { 2) Western } \\
\text { margin of } \\
\text { West Burma } \\
\text { Block. Fig. } \\
27 C\end{array}$ & $\begin{array}{l}\text { Overcomes the } \\
\text { disadvantage of } 1 \text { ) } \\
\text { above. In place on } \\
\text { Sundaland margin in } \\
\text { Triassic. }\end{array}$ & $\begin{array}{l}\text { Some issues of how to get Pane } \\
\text { Chaung Formation so distal in the } \\
\text { accretionary prism. Problematic } \\
\text { location to explain development of } \\
\text { Woyla Arc by rifting from West } \\
\text { Burma, hence modification 3) }\end{array}$ & $\begin{array}{l}\text { Passive } \\
\text { margin } \\
\text { deposits, } \\
\text { predominan } \\
\text { tly in upper } \\
\text { plate of } \\
\text { subduction } \\
\text { zone. }\end{array}$ & $\begin{array}{l}\text { Sevastjanova et al. } \\
\text { (2016) }\end{array}$ \\
\hline $\begin{array}{l}\text { 3) Eastern } \\
\text { margin of } \\
\text { block rifted } \\
\text { from West } \\
\text { Burma }\end{array}$ & $\begin{array}{l}\text { Modification of 2) } \\
\text { above to explain } \\
\text { presence of Pane } \\
\text { Chaung Formation in } \\
\text { footwall of ophiolite } \\
\text { belt. Fits with scenario } \\
\text { of Jurassic rifting to } \\
\text { create the Woyla Arc. }\end{array}$ & $\begin{array}{l}\text { Requires collision of continental } \\
\text { block with IBR. Where is evidence for } \\
\text { that block, why did subduction not } \\
\text { cease? Is complete subduction of } \\
\text { hyper-extended continental crust } \\
\text { feasible? Tectonic slicing in } \\
\text { accretionary type ophiolite can also } \\
\text { explain Pane Chaung position with } \\
\text { respect to ophiolite belt. } \\
\text { Palaeomagnetic data in favour of } \\
\text { West Burma Block (Westerweel et } \\
\text { al., 2019) }\end{array}$ & $\begin{array}{l}\text { Rifted } \\
\text { margin of } \\
\text { IBR and } \\
\text { continental } \\
\text { fragment, } \\
\text { i.e. position } \\
\text { both } \\
\text { oceanward } \\
\text { and } \\
\text { landward of } \\
\text { IBR. }\end{array}$ & $\begin{array}{l}\text { This study. } \\
\text { Zahirovic et al. } \\
\text { (2016) -reference } \\
\text { for plate scenario, } \\
\text { not specifically for } \\
\text { discussion of Pane } \\
\text { Chaung Formation. }\end{array}$ \\
\hline $\begin{array}{l}\text { 4) Mt Victoria } \\
\text { Land } \\
\text { microplate } \\
\text { rifted from } \\
\text { India. Figs. } \\
27 \mathrm{~B}, 29 \text {. }\end{array}$ & $\begin{array}{l}\text { Easy to explain } \\
\text { presence of Pane } \\
\text { Chaung Formation in } \\
\text { footwall of ophiolites }\end{array}$ & Same as 3) above & $\begin{array}{l}\text { Oceanward } \\
\text { of IBR }\end{array}$ & $\begin{array}{l}\text { Mitchell, 1986, } \\
\text { 1989; Mitchell et al. } \\
\text { (2010) } \\
\text { Acharyya,(2007), Ra } \\
\text { ngin et al. (2013). }\end{array}$ \\
\hline $\begin{array}{l}\text { 5) Part of } \\
\text { Indian } \\
\text { Continental } \\
\text { margin. Fig. } \\
\text { 27A. }\end{array}$ & $\begin{array}{l}\text { Simple explanation. } \\
\text { Removes problem of } \\
\text { 4) above regarding } \\
\text { lack of evidence for a } \\
\text { continental block. } \\
\text { Best fits provenance } \\
\text { data as similar to } \\
\text { Langjiexue Group } \\
\text { (Wang et al., 2016). }\end{array}$ & $\begin{array}{l}\text { Pane Chaung Formation sealed by } \\
105 \text { Ma and } 70 \text { Ma unconformities. } \\
\text { Hence involvement of Pane Chaung } \\
\text { in IBR too early for Indian continental } \\
\text { margin to have introduced formation } \\
\text { into IBR. Hence variants on 4) } \\
\text { devised, or as part of West Burma } \\
\text { Block (2) above. }\end{array}$ & $\begin{array}{l}\text { Oceanward } \\
\text { of IBR }\end{array}$ & Mitchell, (1981) \\
\hline $\begin{array}{l}\text { 6) Northern } \\
\text { Australian } \\
\text { part of } \\
\text { Gondwana } \\
\text { margin }\end{array}$ & $\begin{array}{l}\text { Part of large turbidite } \\
\text { complex. Could be } \\
\text { part of same late } \\
\text { Jurassic rifting phase } \\
\text { as Argo Block. Arrives } \\
\text { off Sundaland margin } \\
\text { in mid Cretaceous. }\end{array}$ & $\begin{array}{l}\text { Difficult to fit long IBR subduction } \\
\text { history into this scenario. Does not } \\
\text { fit with provenance arguments in } \\
\text { Sevastjanova et al. (2016), or origin } \\
\text { as part of Langjiexue Group (Wang et } \\
\text { al., 2016). }\end{array}$ & $\begin{array}{l}\text { Oceanward } \\
\text { of IBR }\end{array}$ & Yao et al. (2017) \\
\hline
\end{tabular}




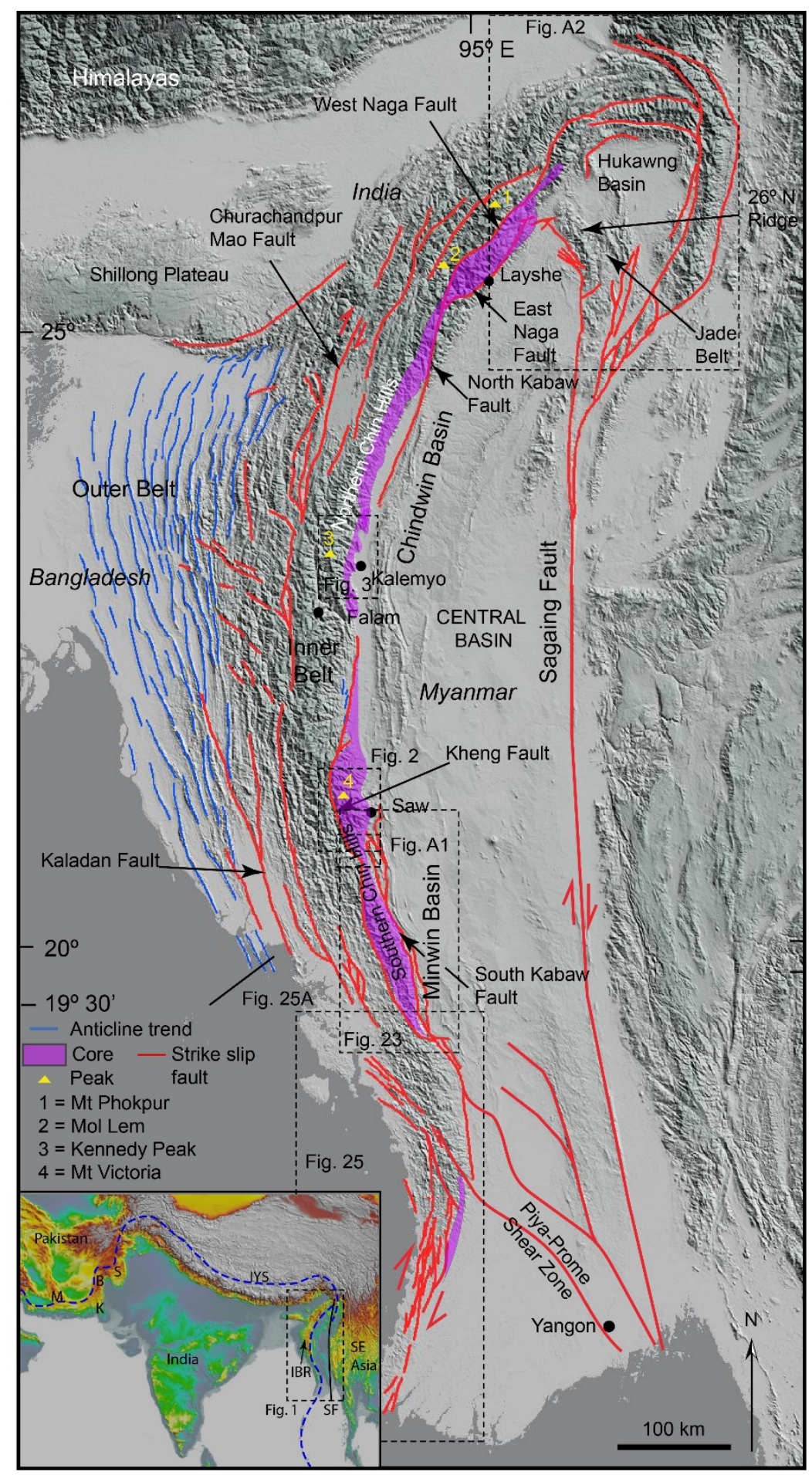

Fig. 1 


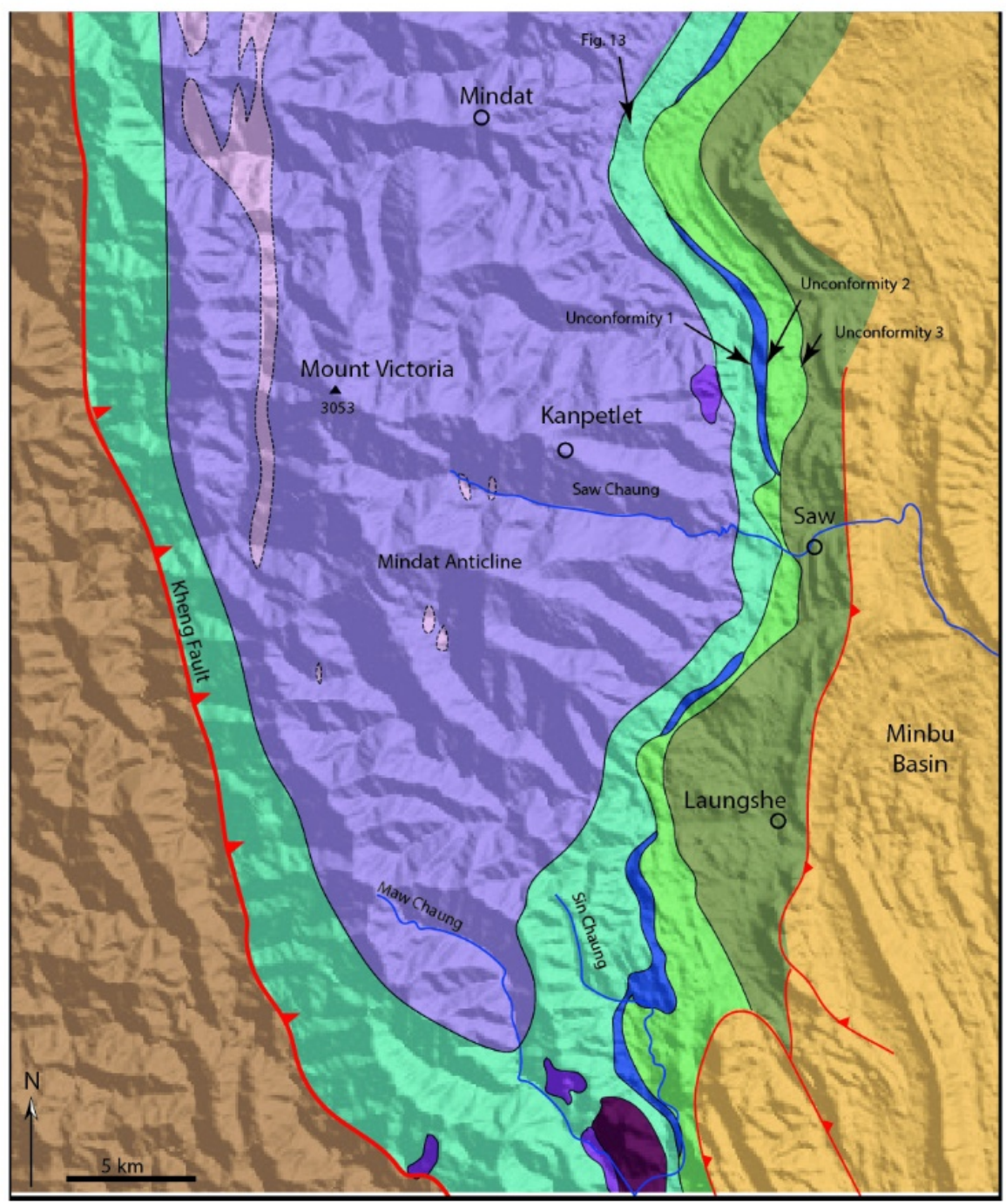

$\square$ Late Cretaceous- $\square$ Pane Chaung $\square$ Ultrabasic $\square$ Exotics zone $\square$ Kanpetlet $\square$ Meta-basalts within $\square$ Palaeogene Flysch $\square$ Formation $\square$ (Melange) $\square$ Schist $\square$ Kanpetlet Schist $\square \begin{aligned} & \text { Paung Chaung } \\ & \text { Formation }\end{aligned} \begin{aligned} & \text { Kabaw } \\ & \text { Formation }\end{aligned}$ Laungshe Shale (Palaeogene) $\square$ Eocene (clastics) of 


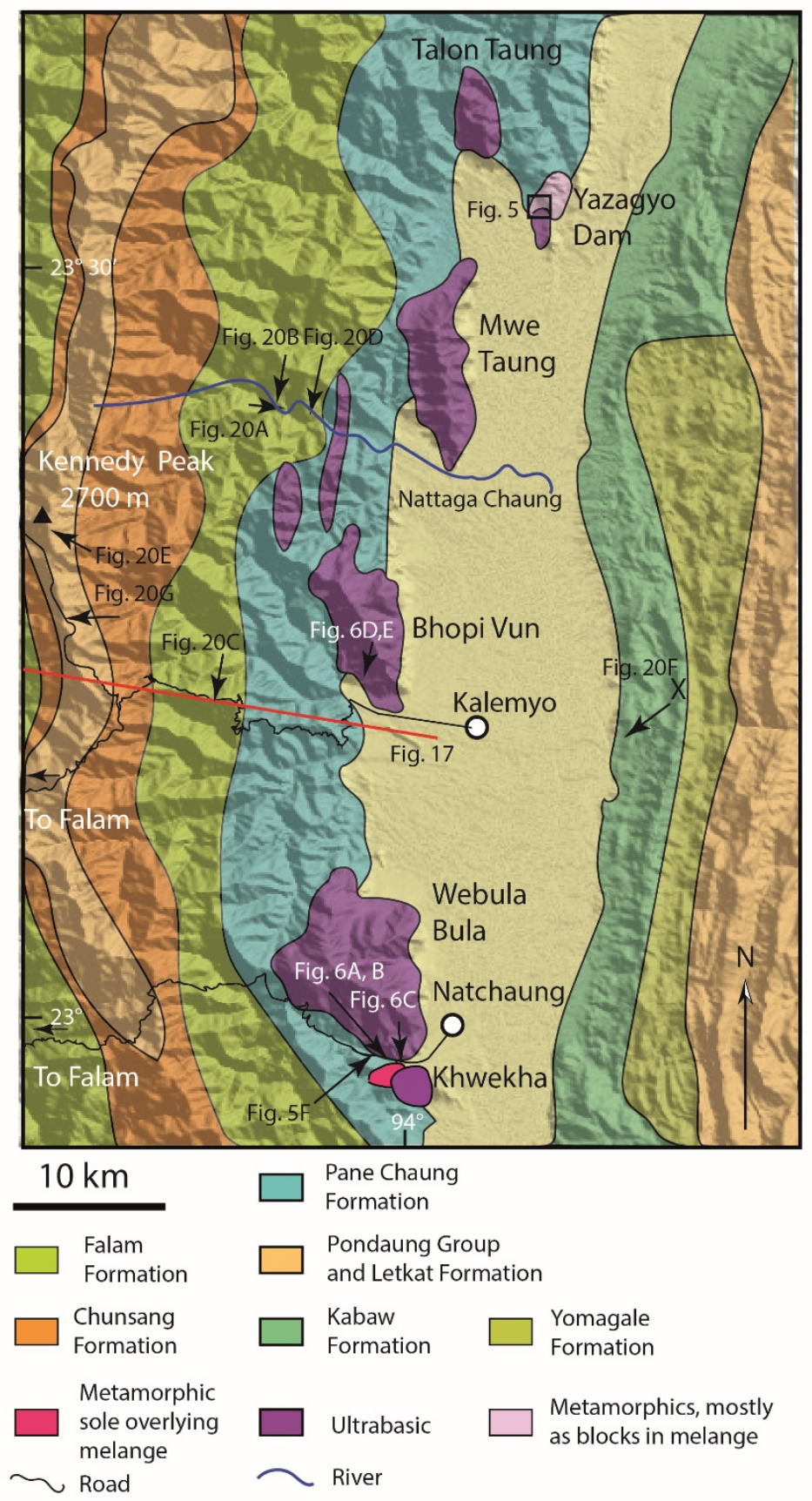

Fig. 3 


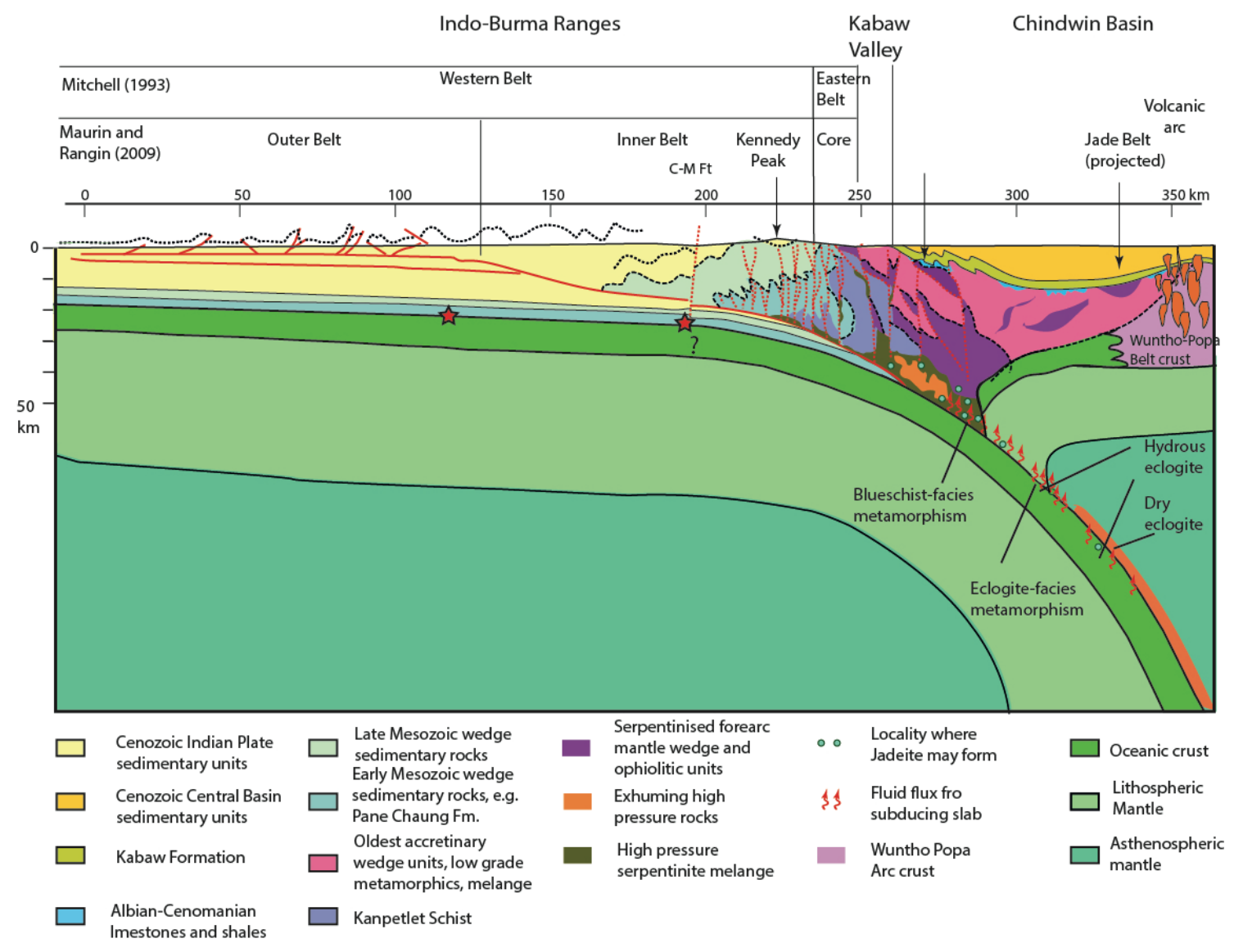



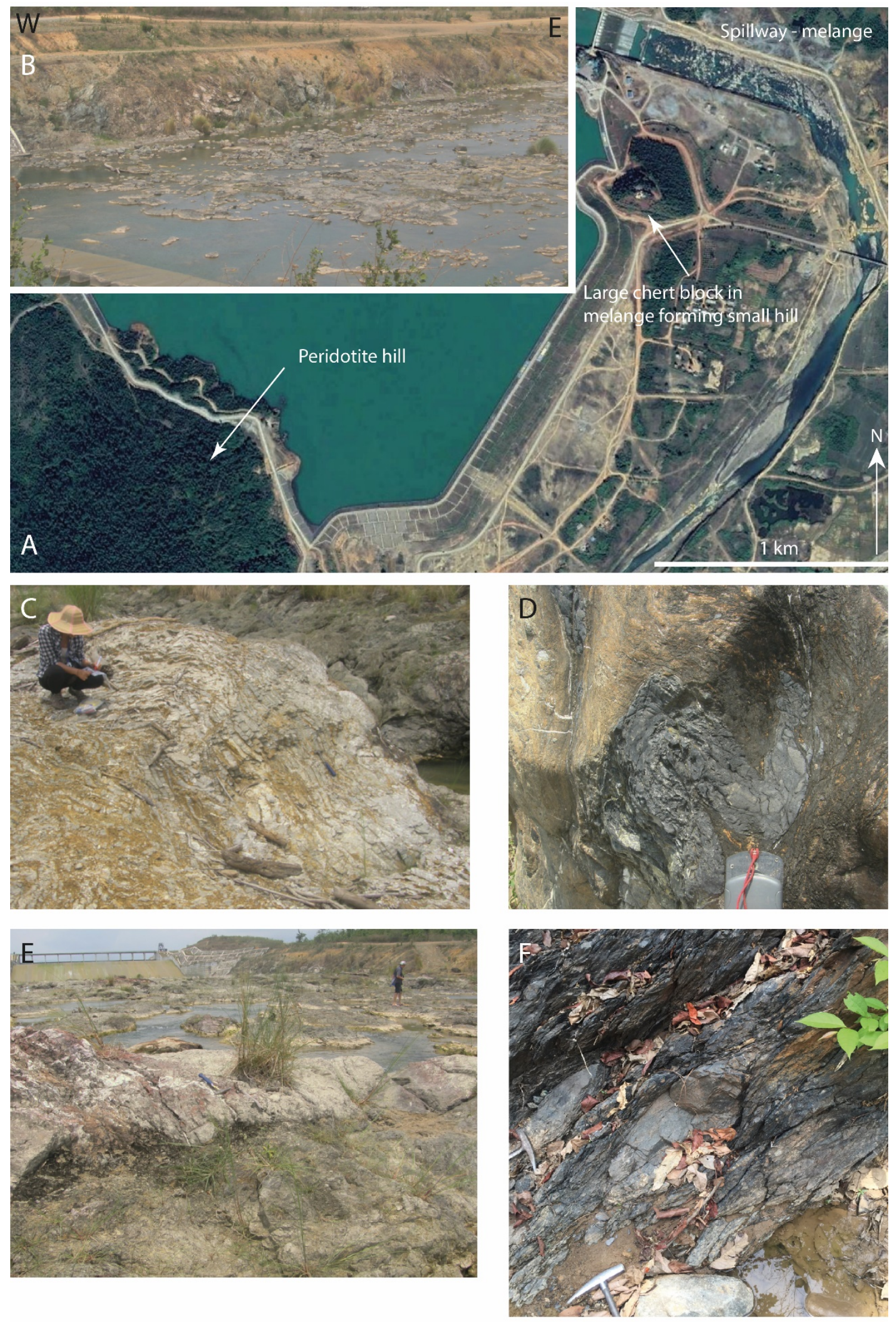

Fig. 5 


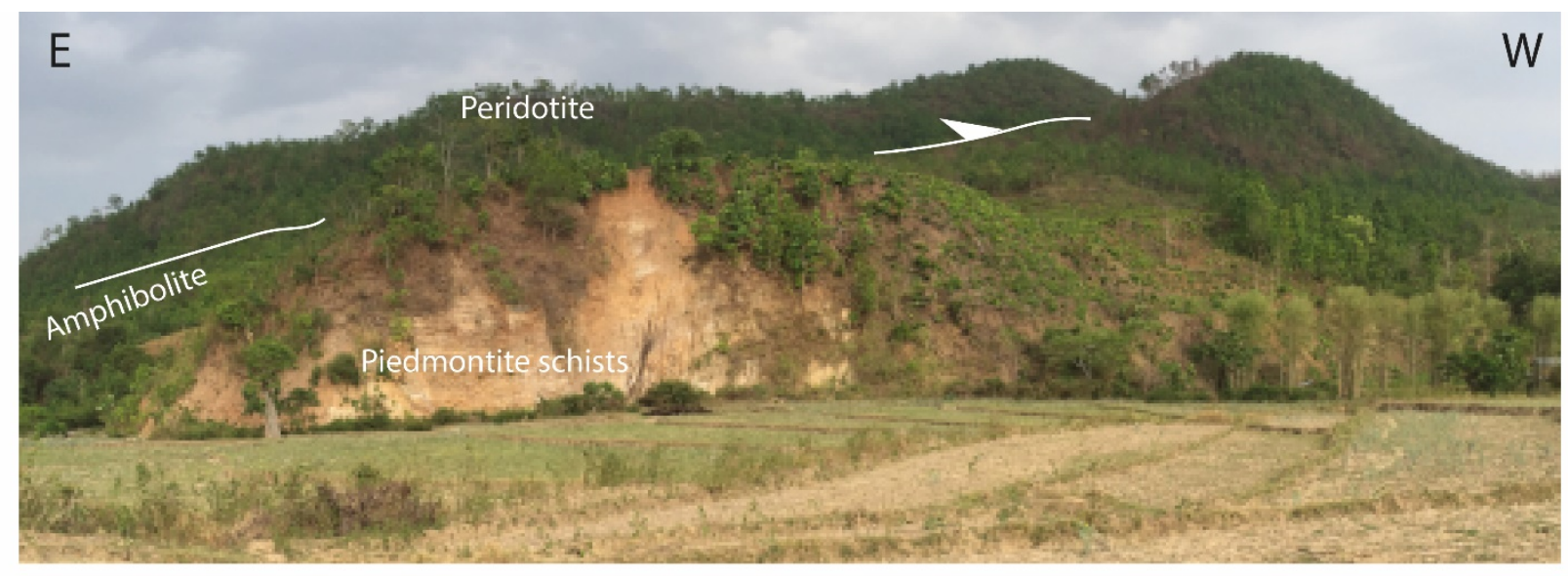

Fig. 6 
Figure 7 (not 5)
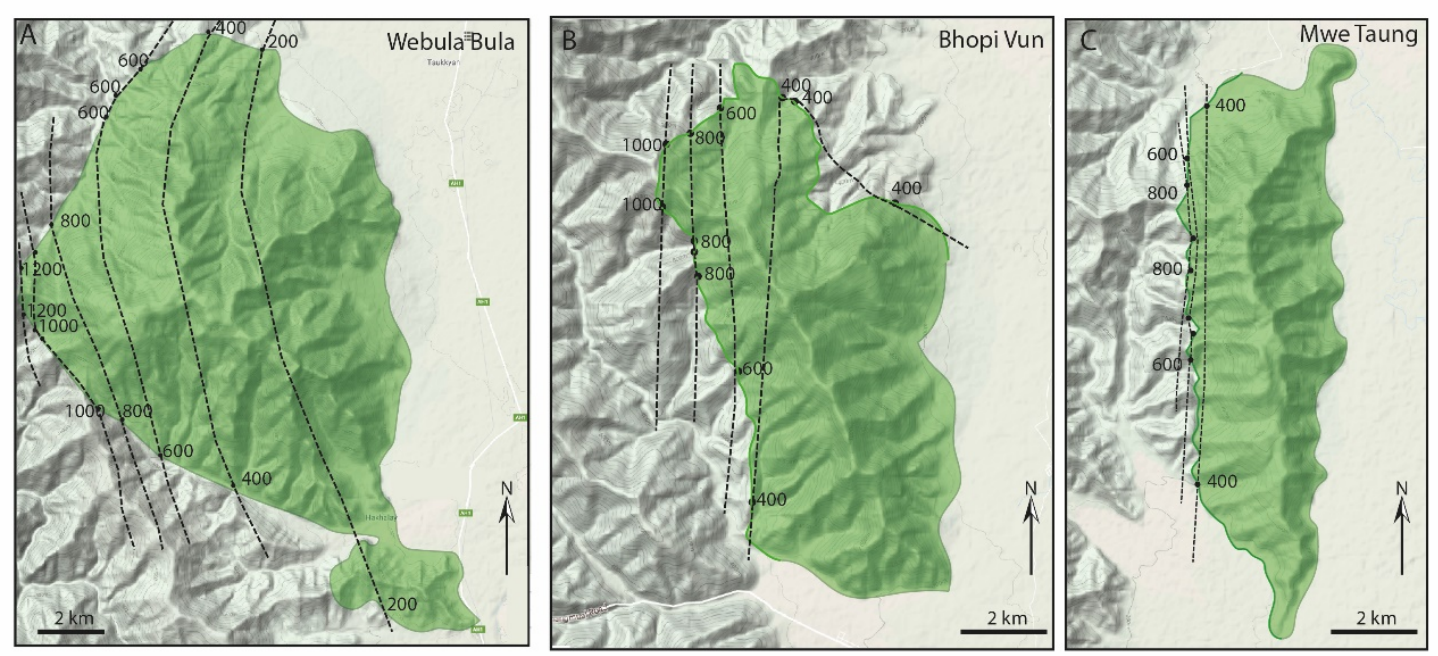

400 Structure contour $(\mathrm{m})$

Peridotite (ophiolite) outcrop

Fig. 5 
Fig 8

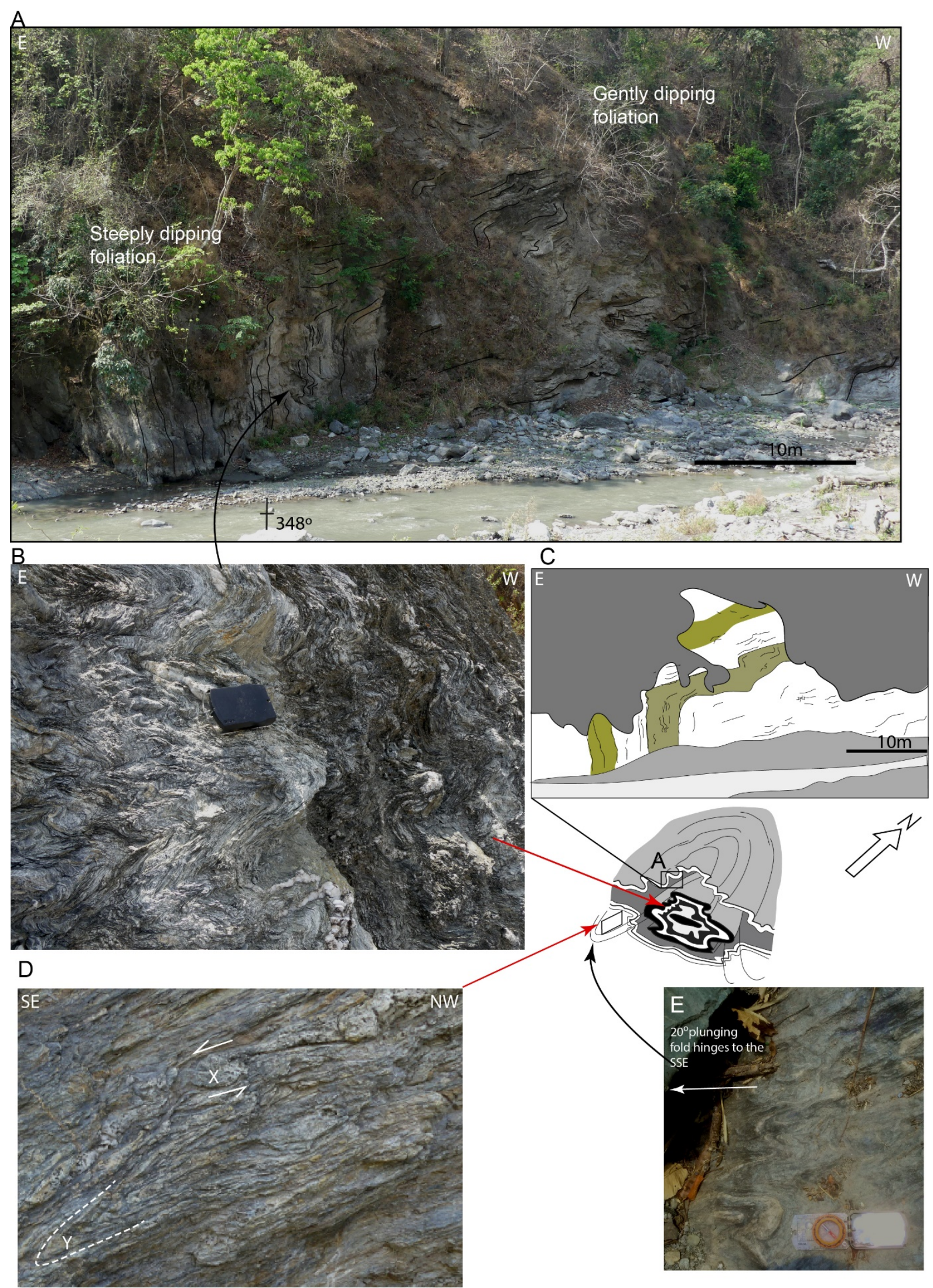



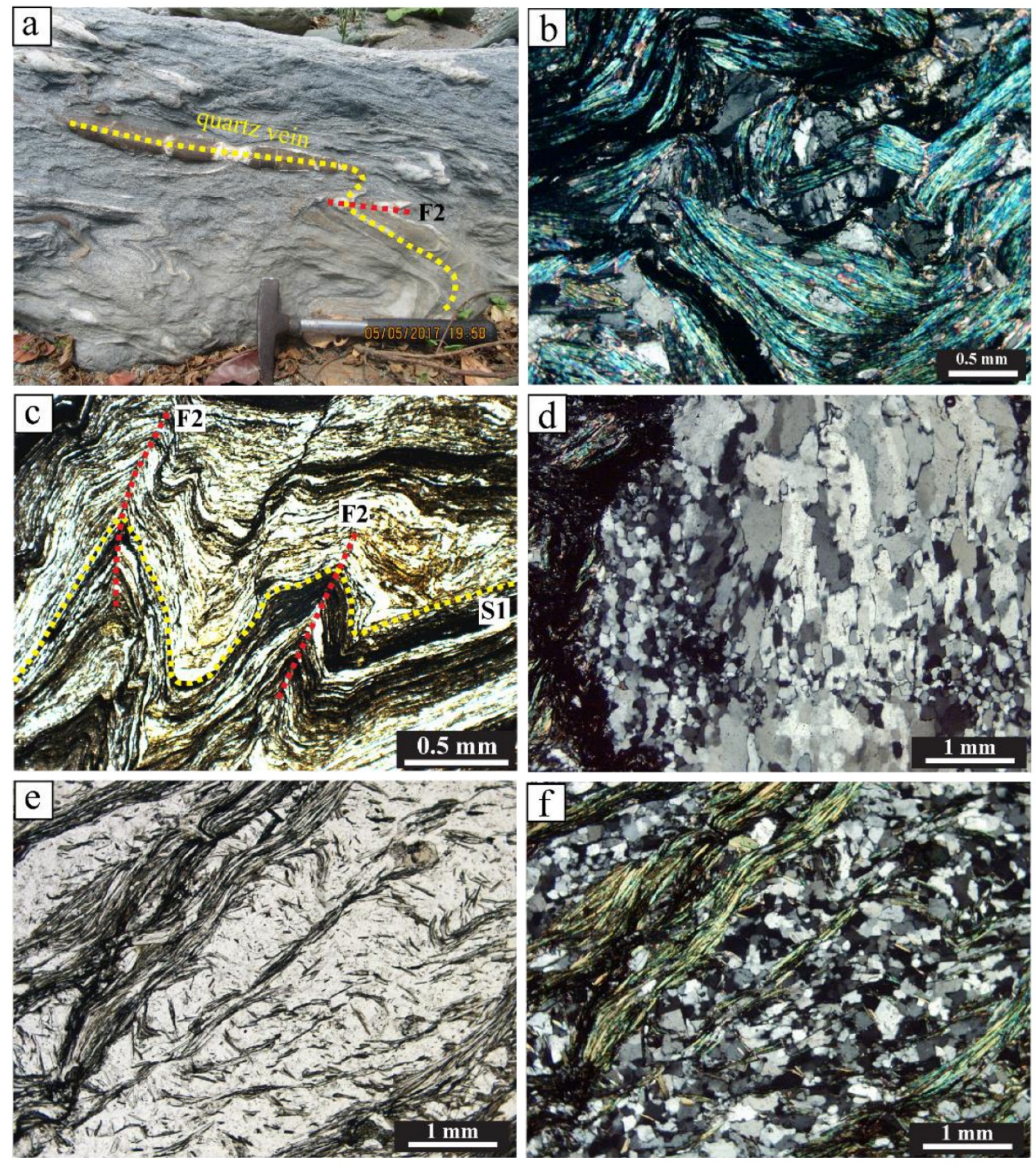

Fig. 9 

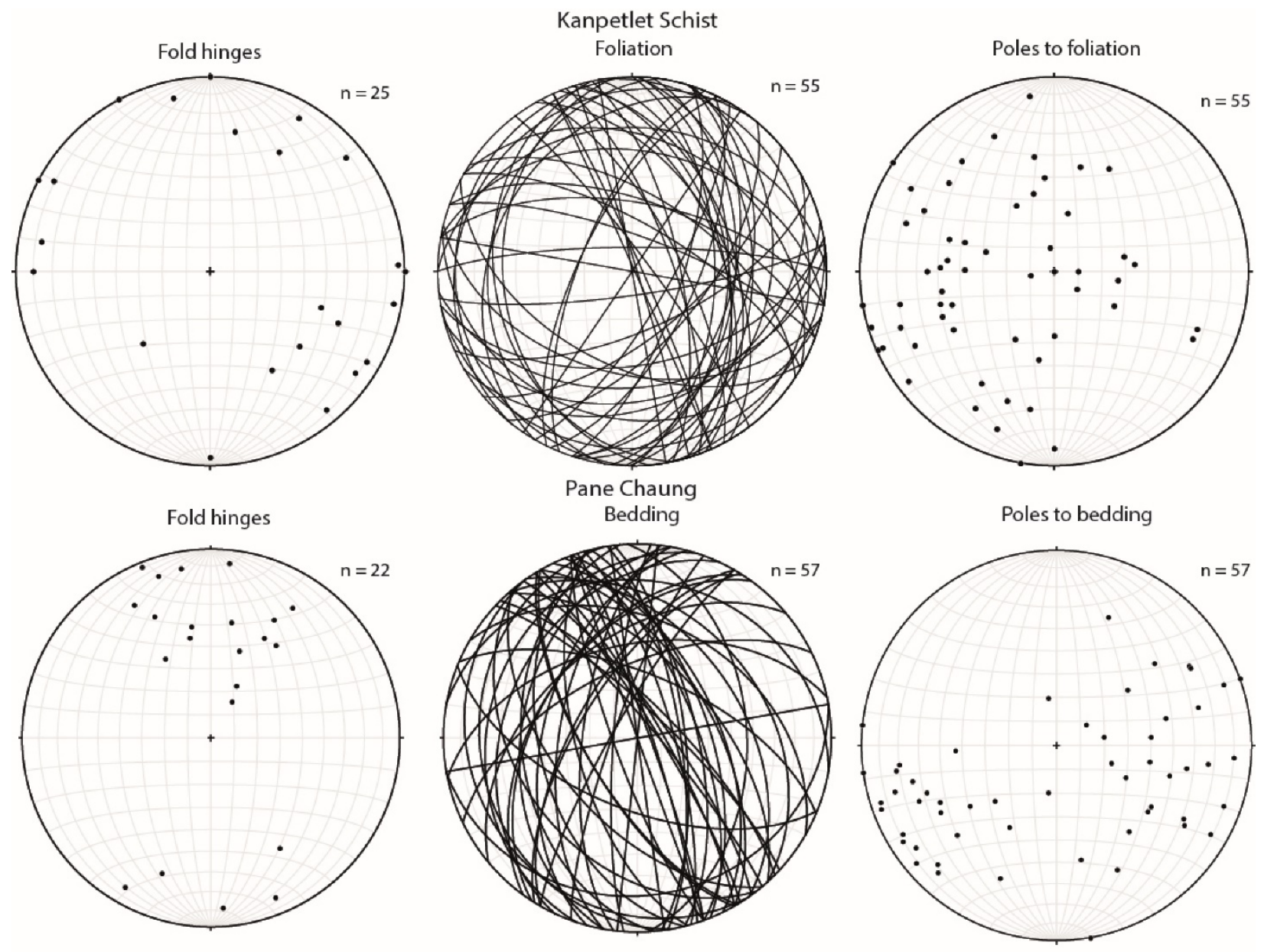

Fig. 10 


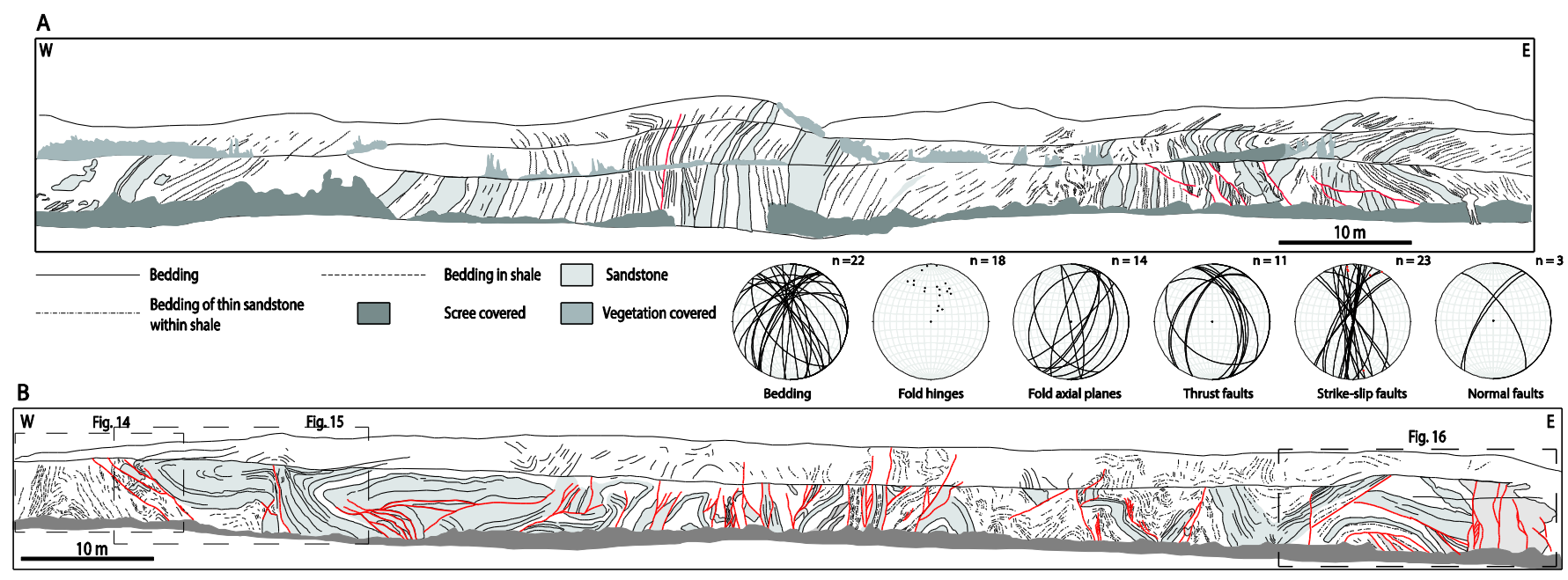

Fig 11 

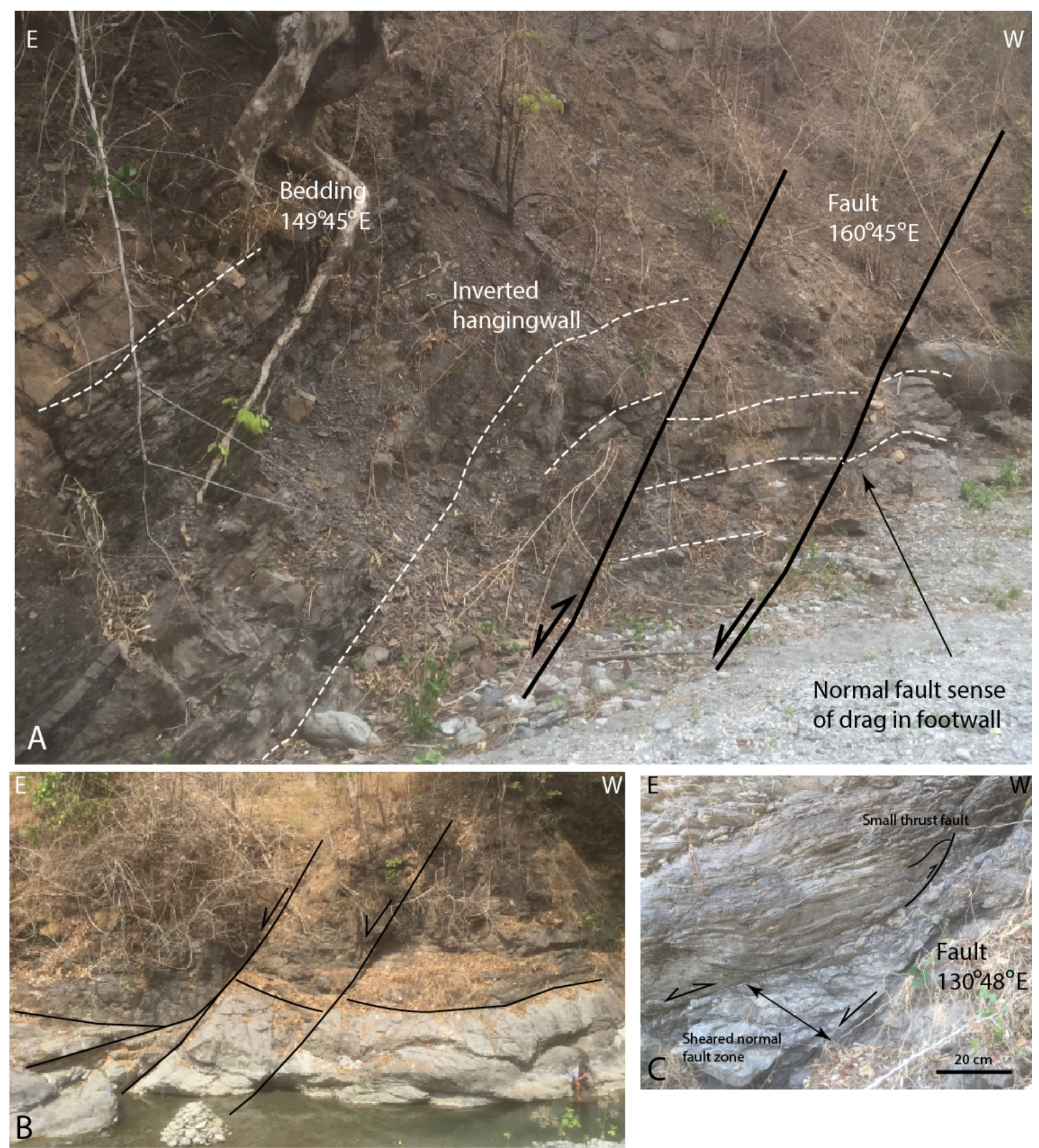

Fig 12 

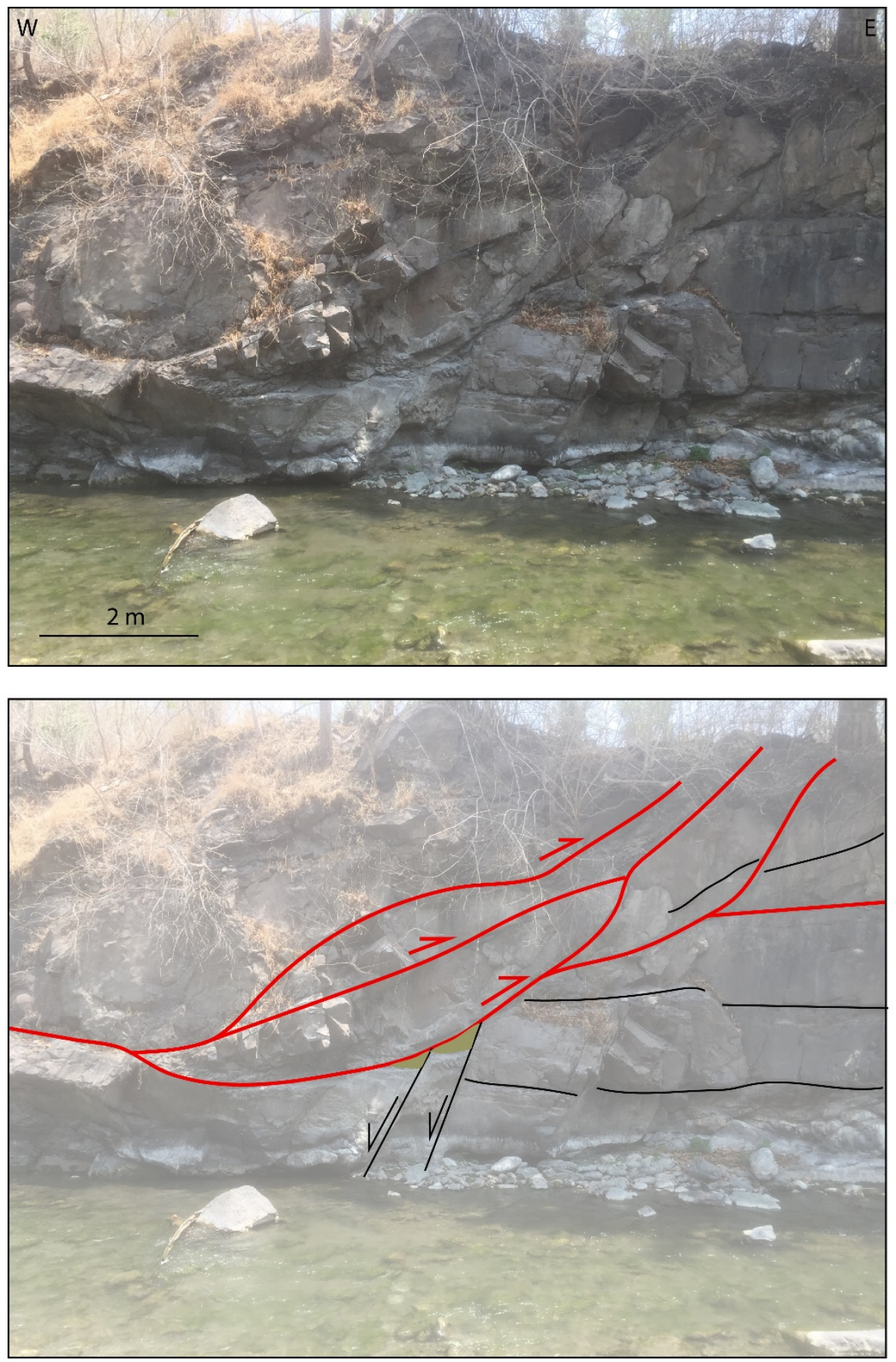

Fig. 13 

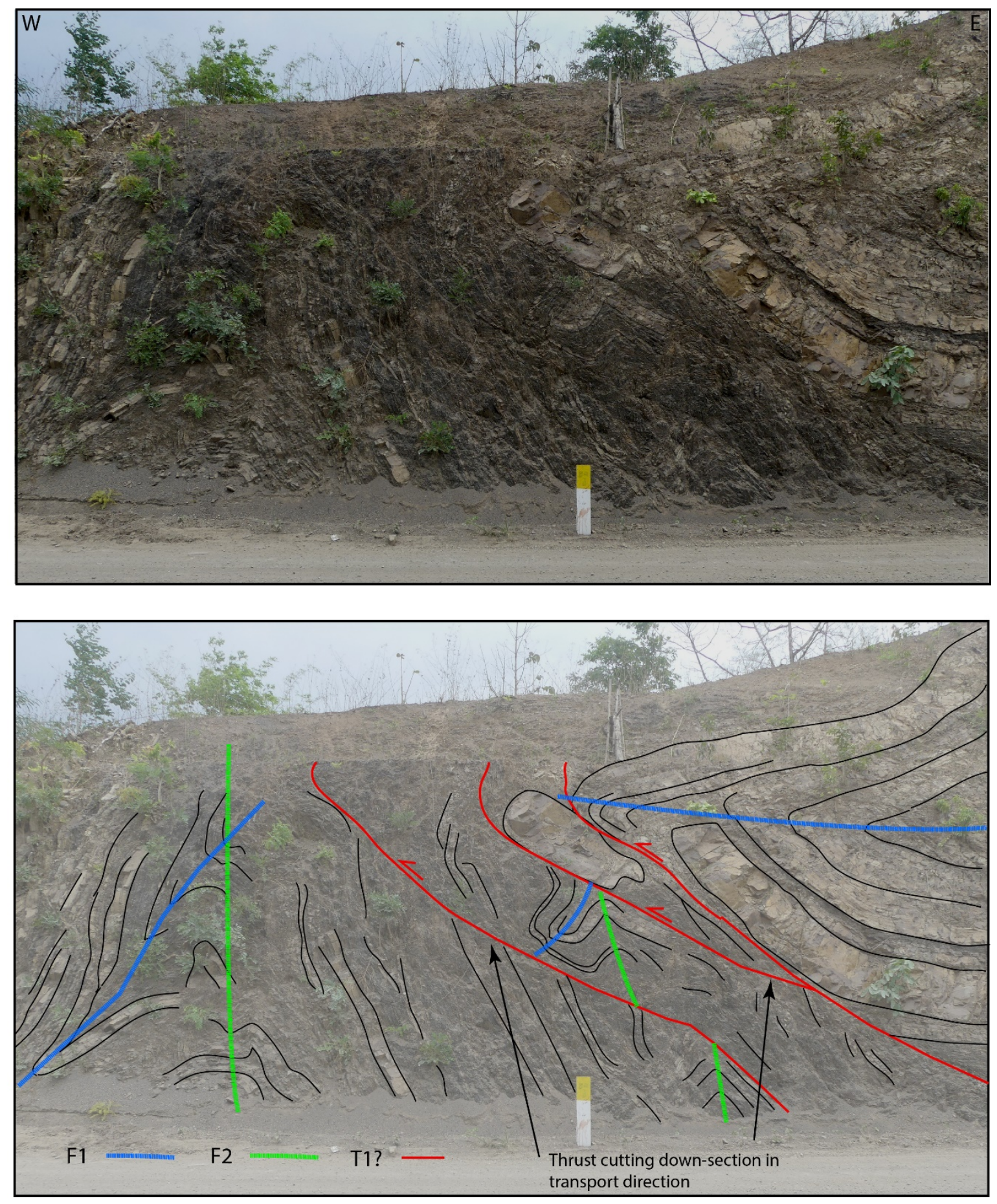

Fig 14 

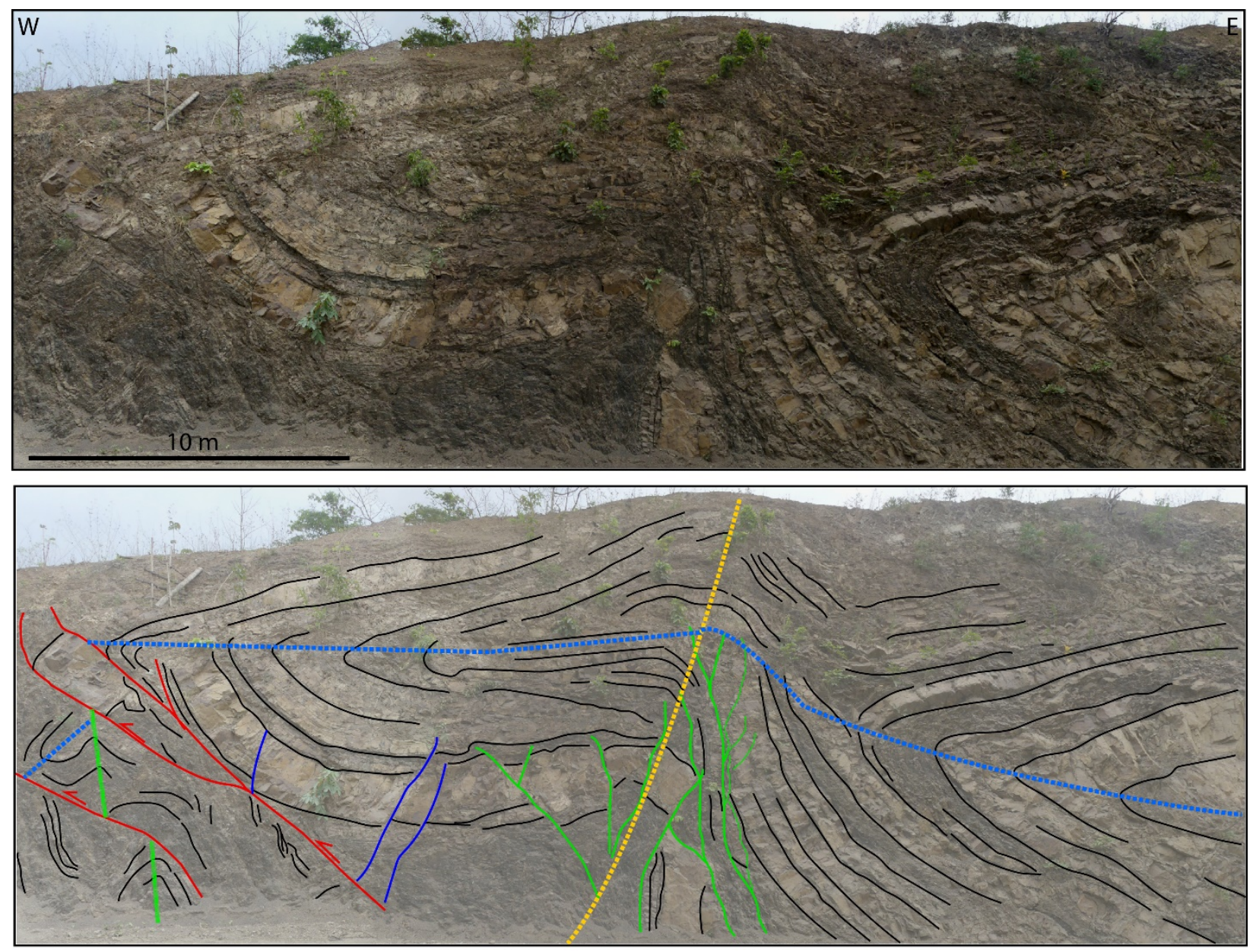

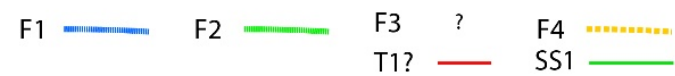

Fig 15 

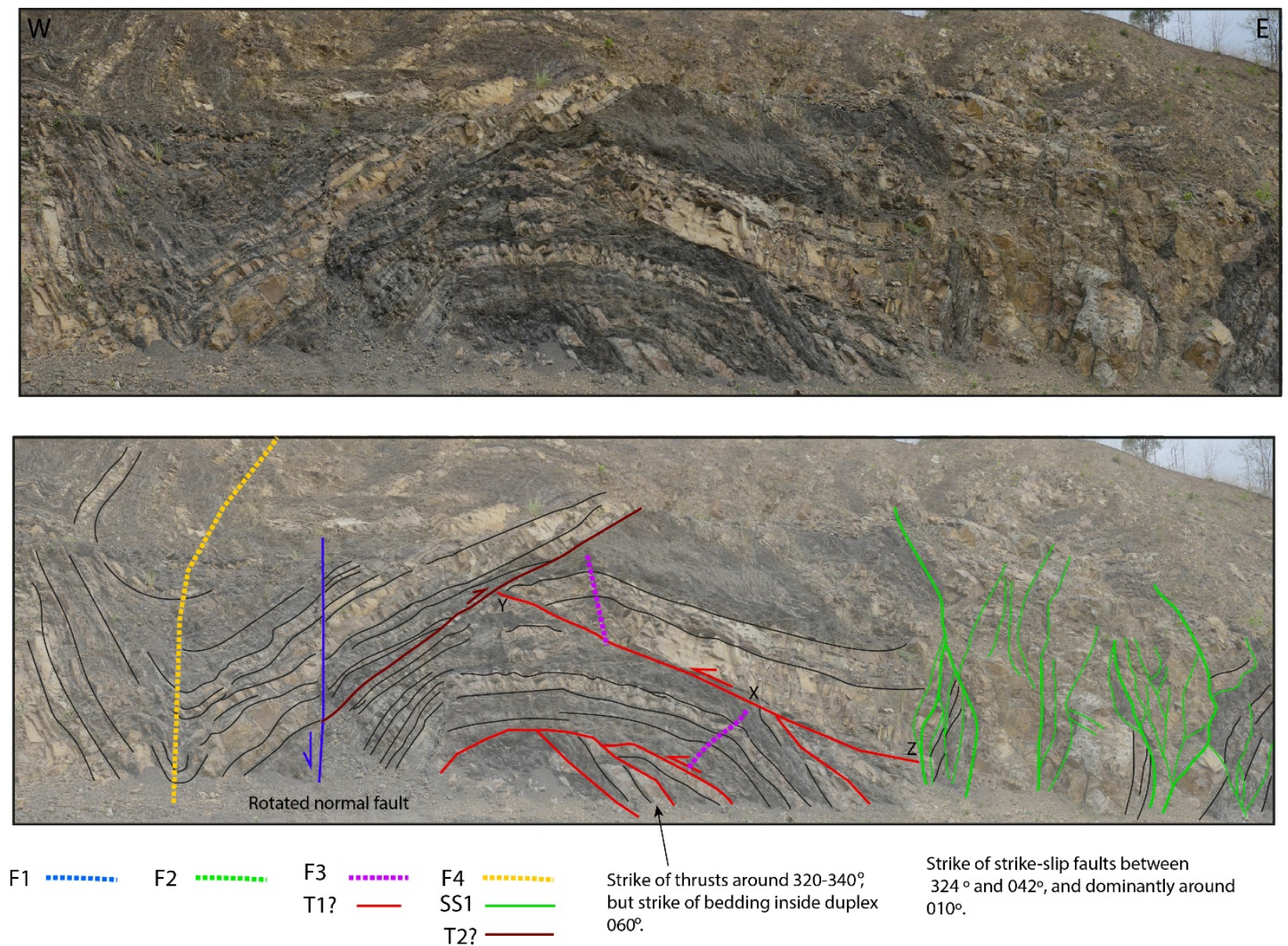

Fig. 16 



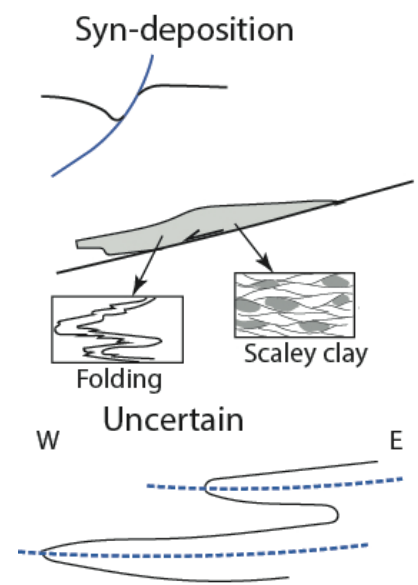

Early, probably gravity-

driven extensional faulting

Some units are mass-transport

complexes, that shear up

competent units into scaley clay units

and also produce early folds (often tight,

to isoclinal, recumbent geometries)

E

Early recumbent folds

tectonic or gravity driven?

F1

\section{Accretionary prism}

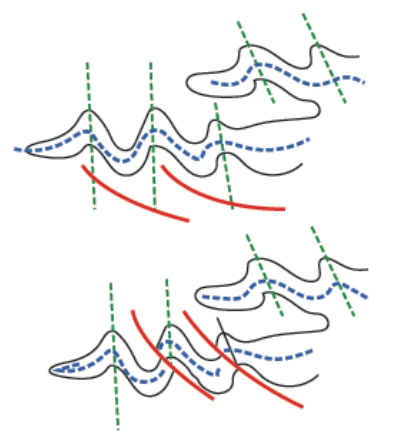

Upright to predominantly

west-verging

F2

Probably accompanied

by thrusting

Out-of sequence thrusting

F3 (?)

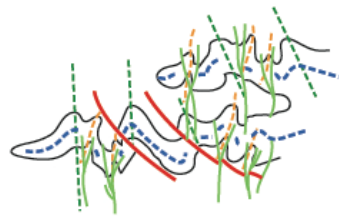

Upright to predominantly east-

verging folds (F 4), accompanied by

dextral strike-slip faulting.

Out-of sequence thrusting may accompany

this phase as well.

These sketches represent outcrop-scale

structures not regional-scale ones

Fig. 17 
Bedding planes and poles
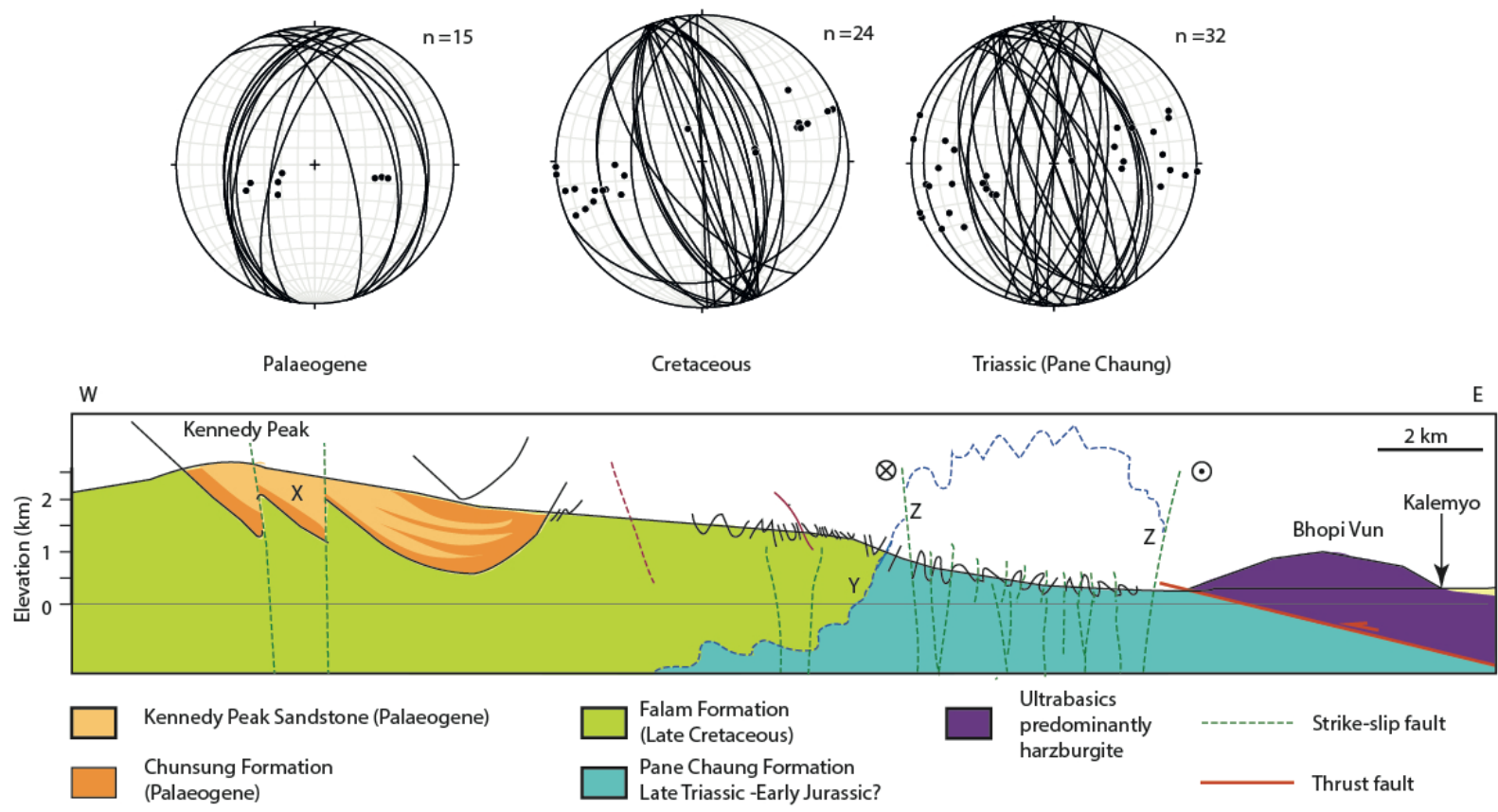

Fig 18 

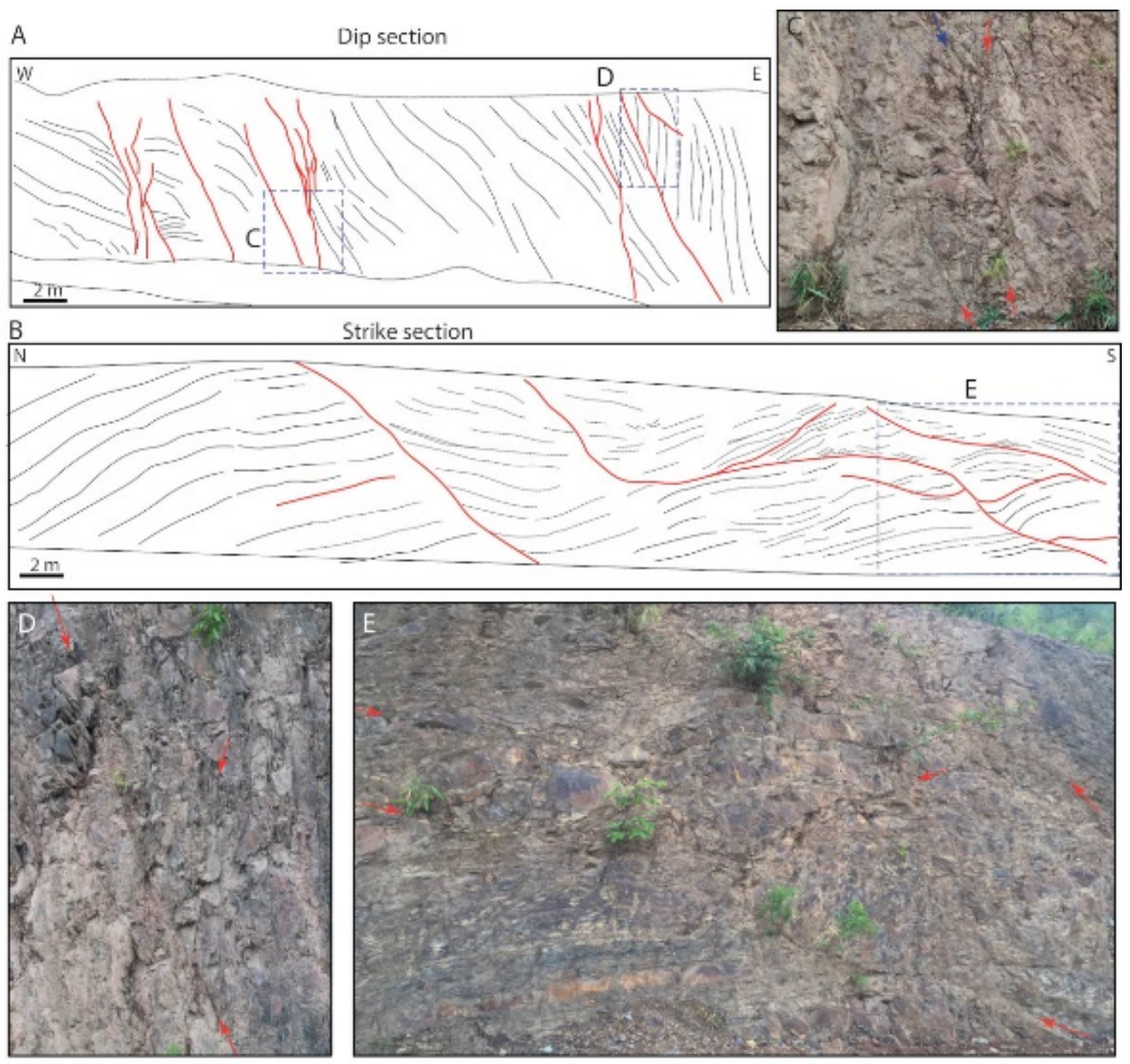

Fig. 19 

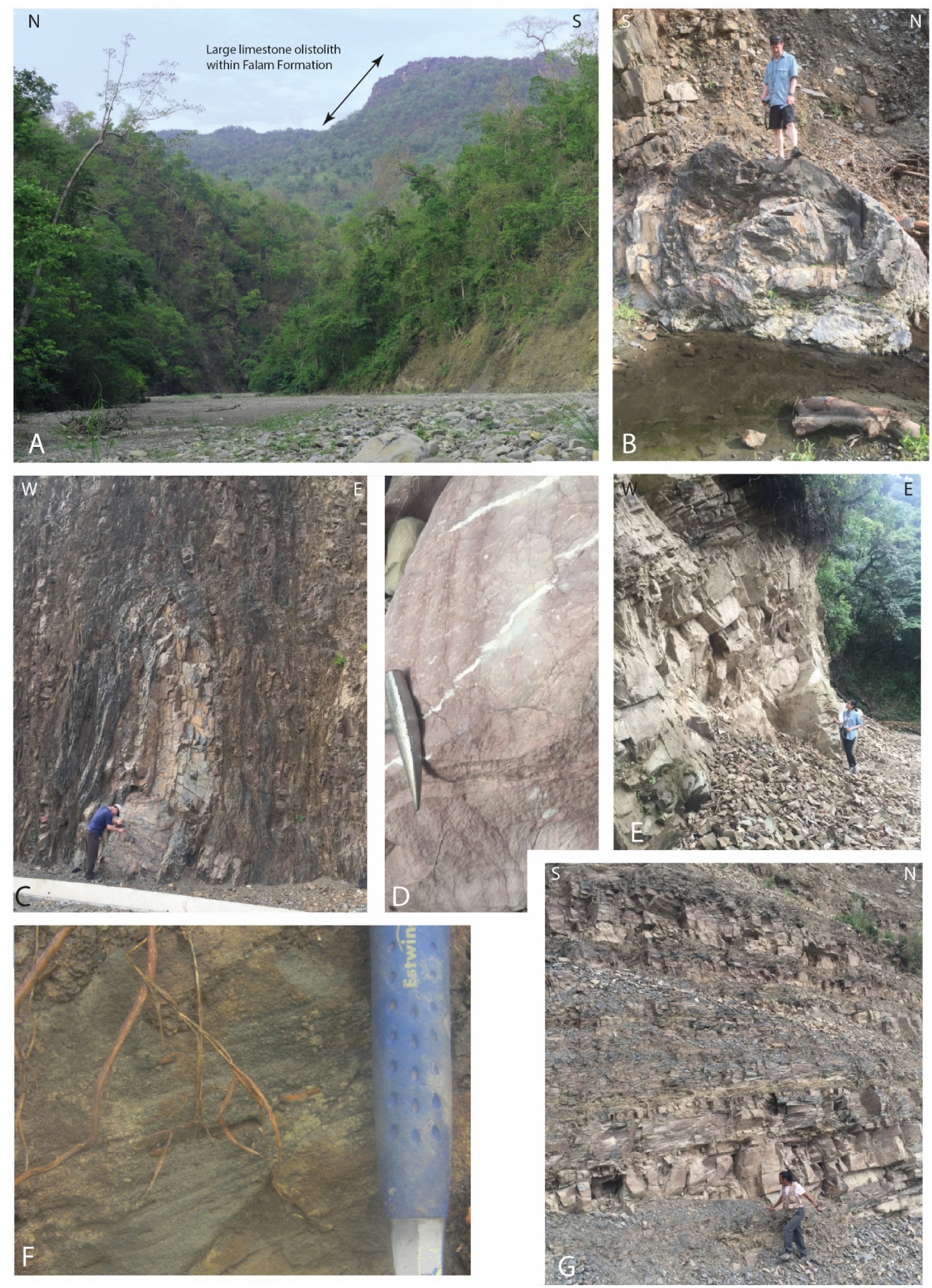

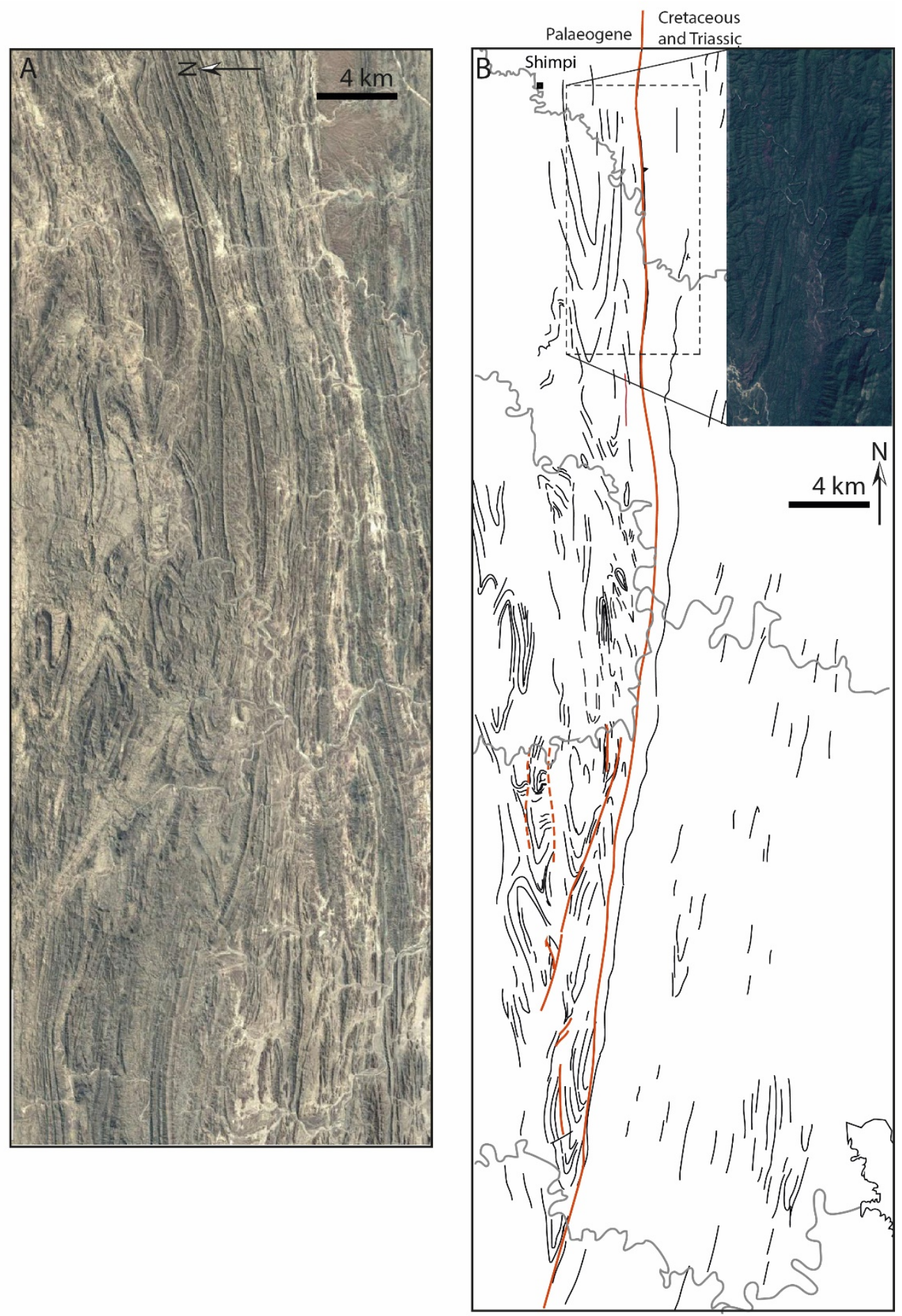

Fig. 21 

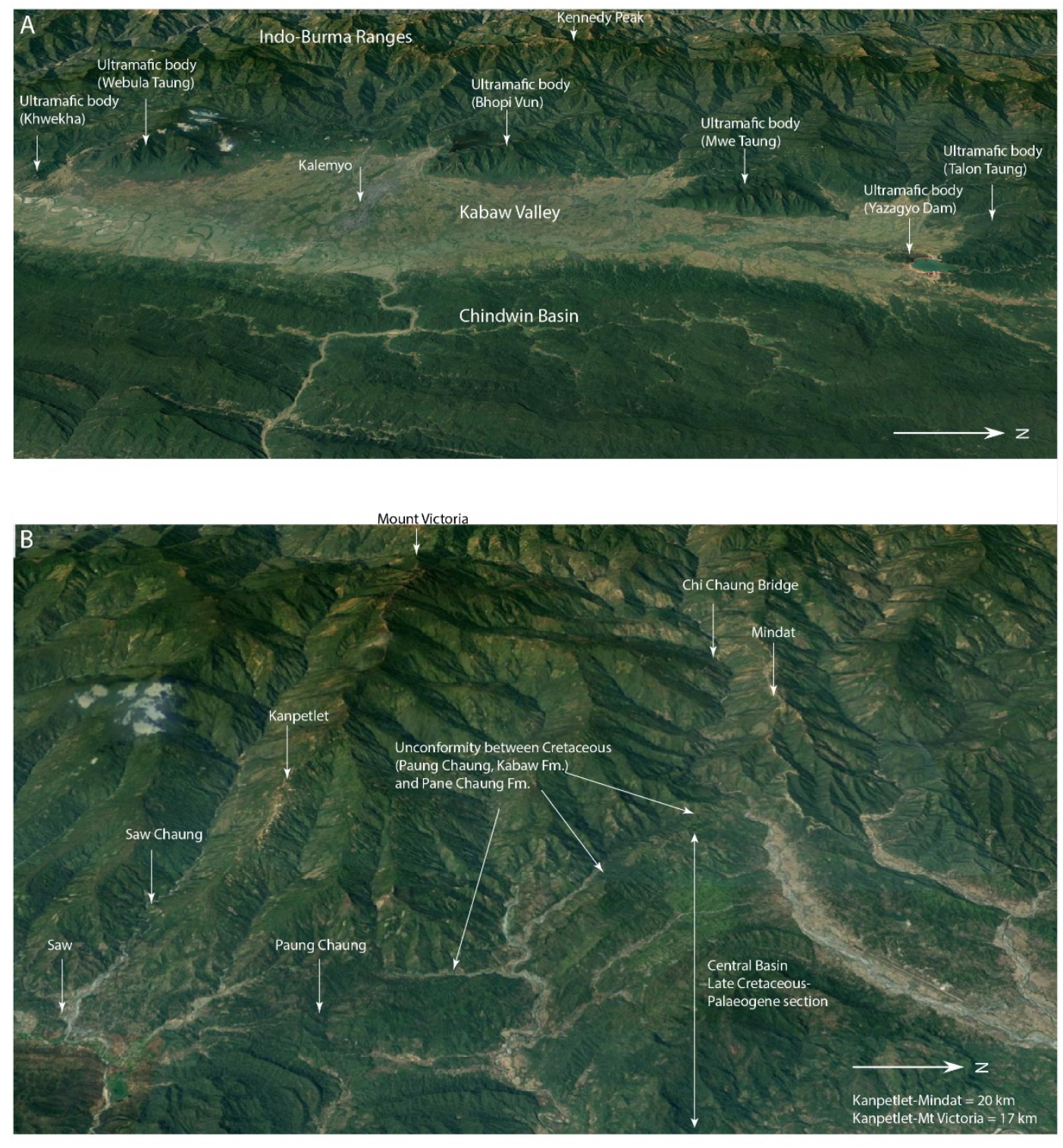

Fig. 22 


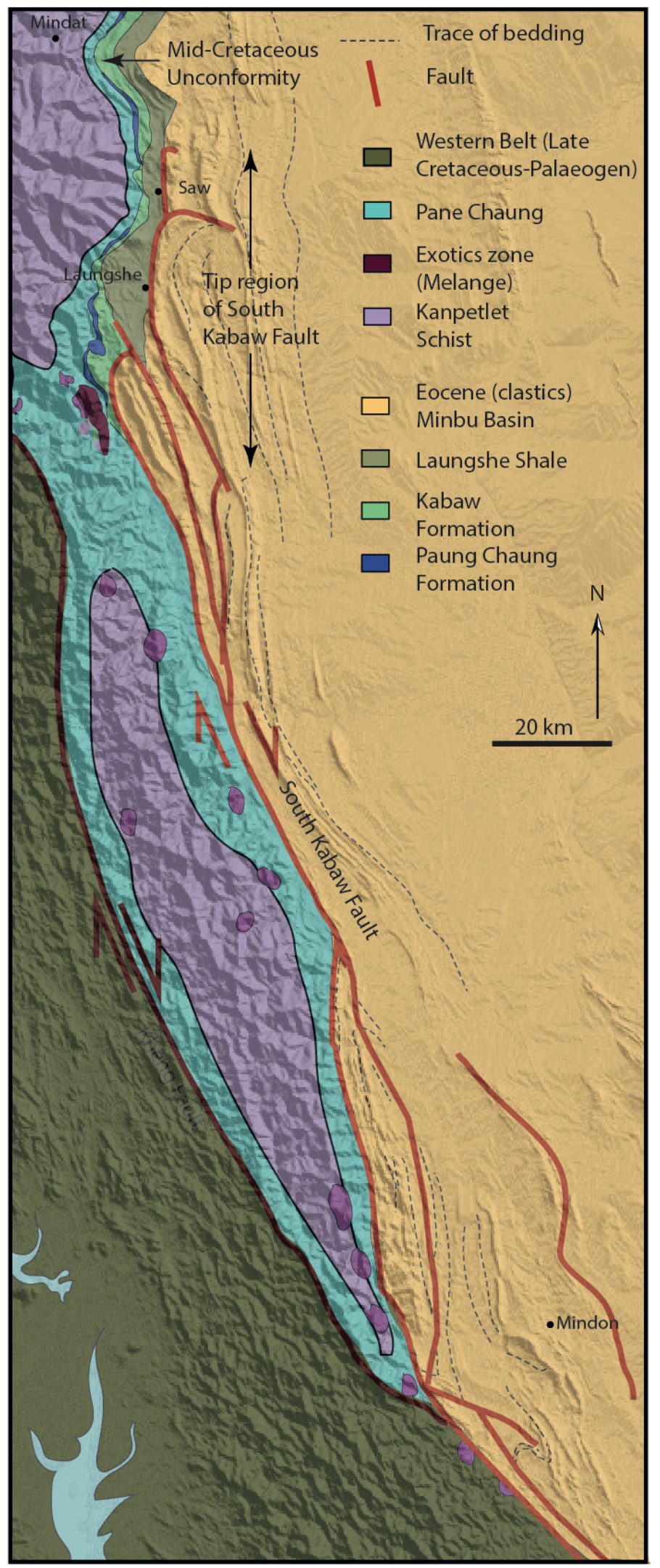

Fig. 23 

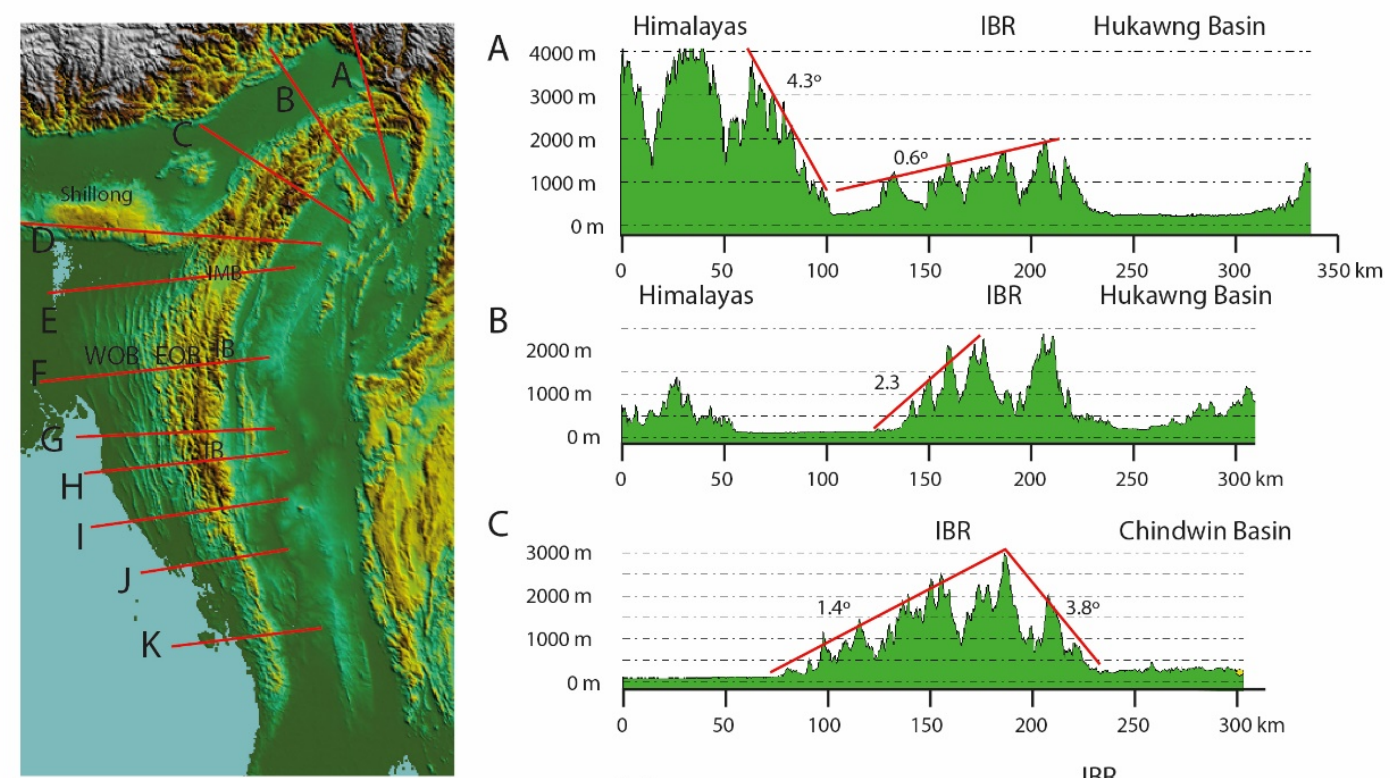

B

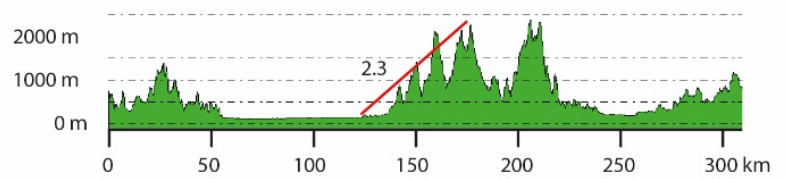

C

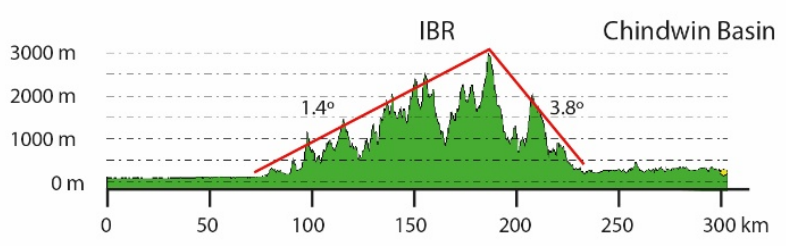

D $2000 \mathrm{~m}$

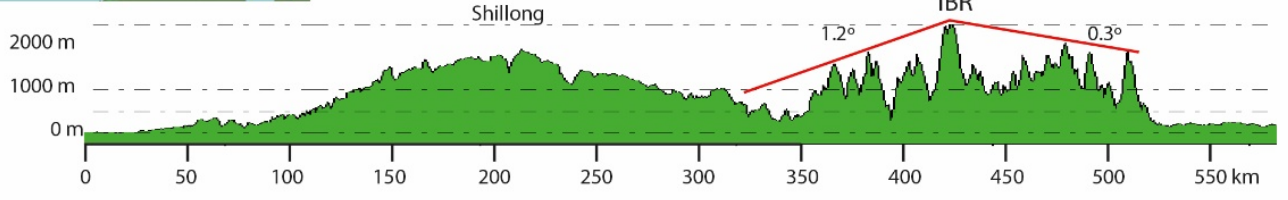

E
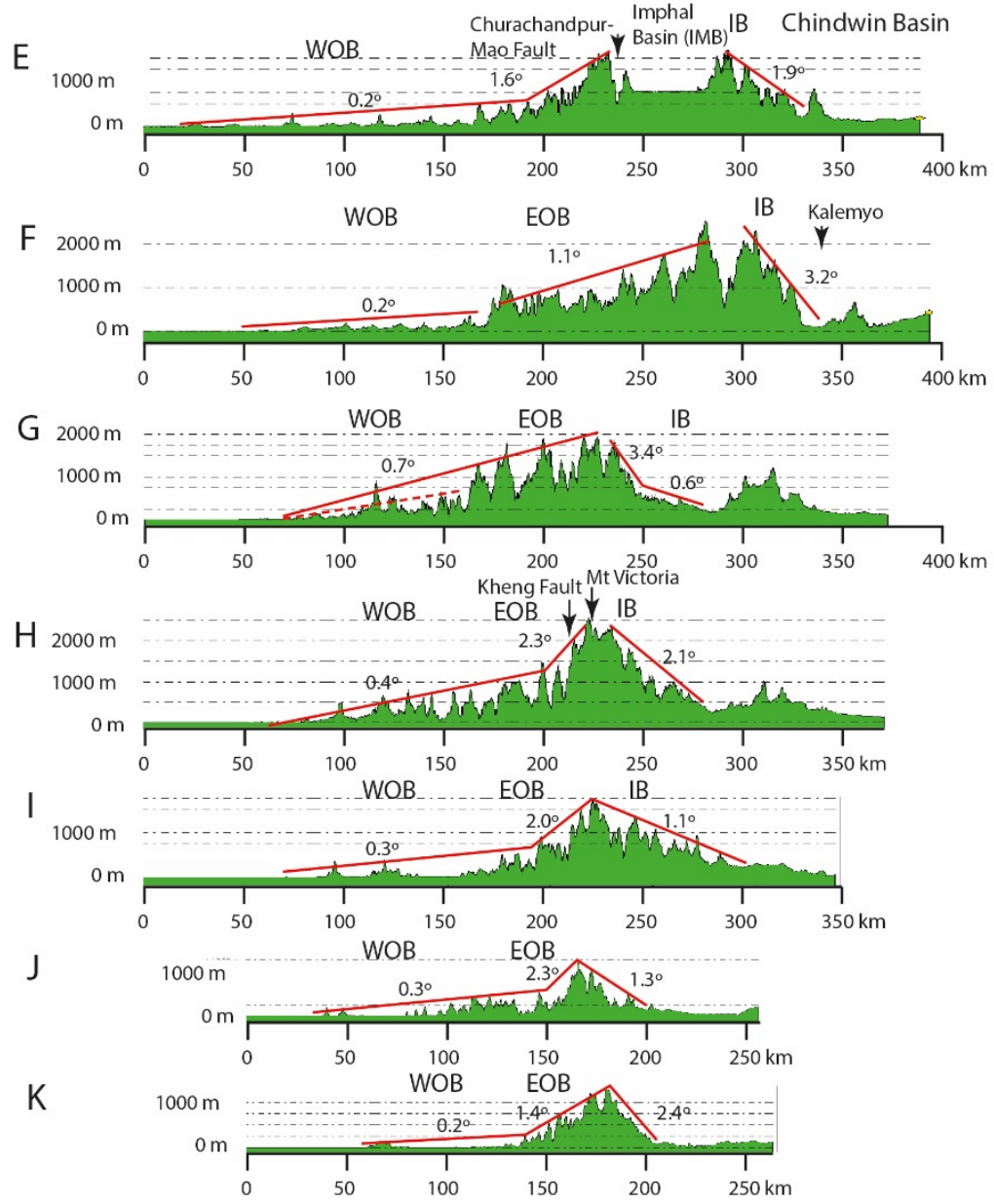

Fig. 24 


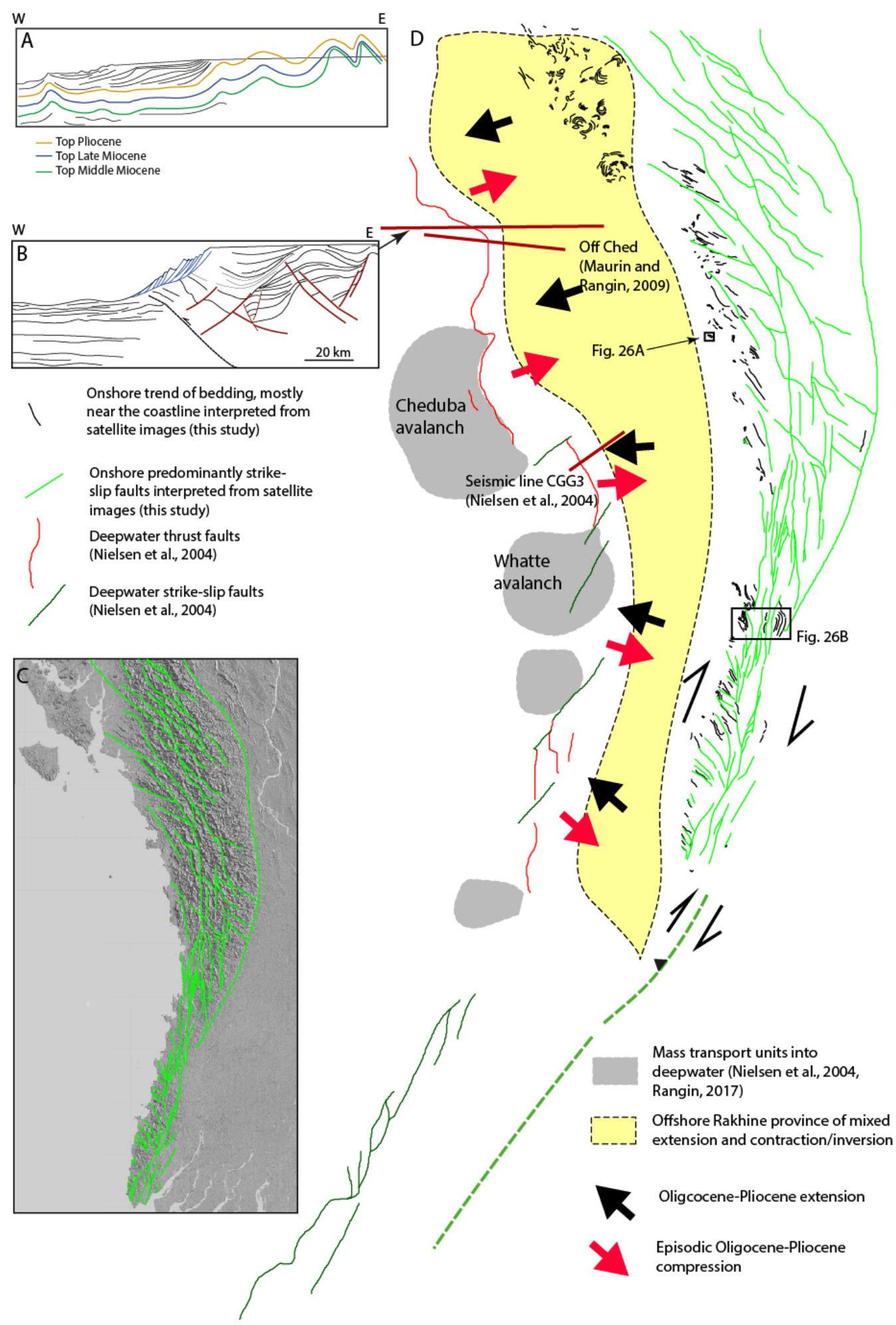

Fig. 25 


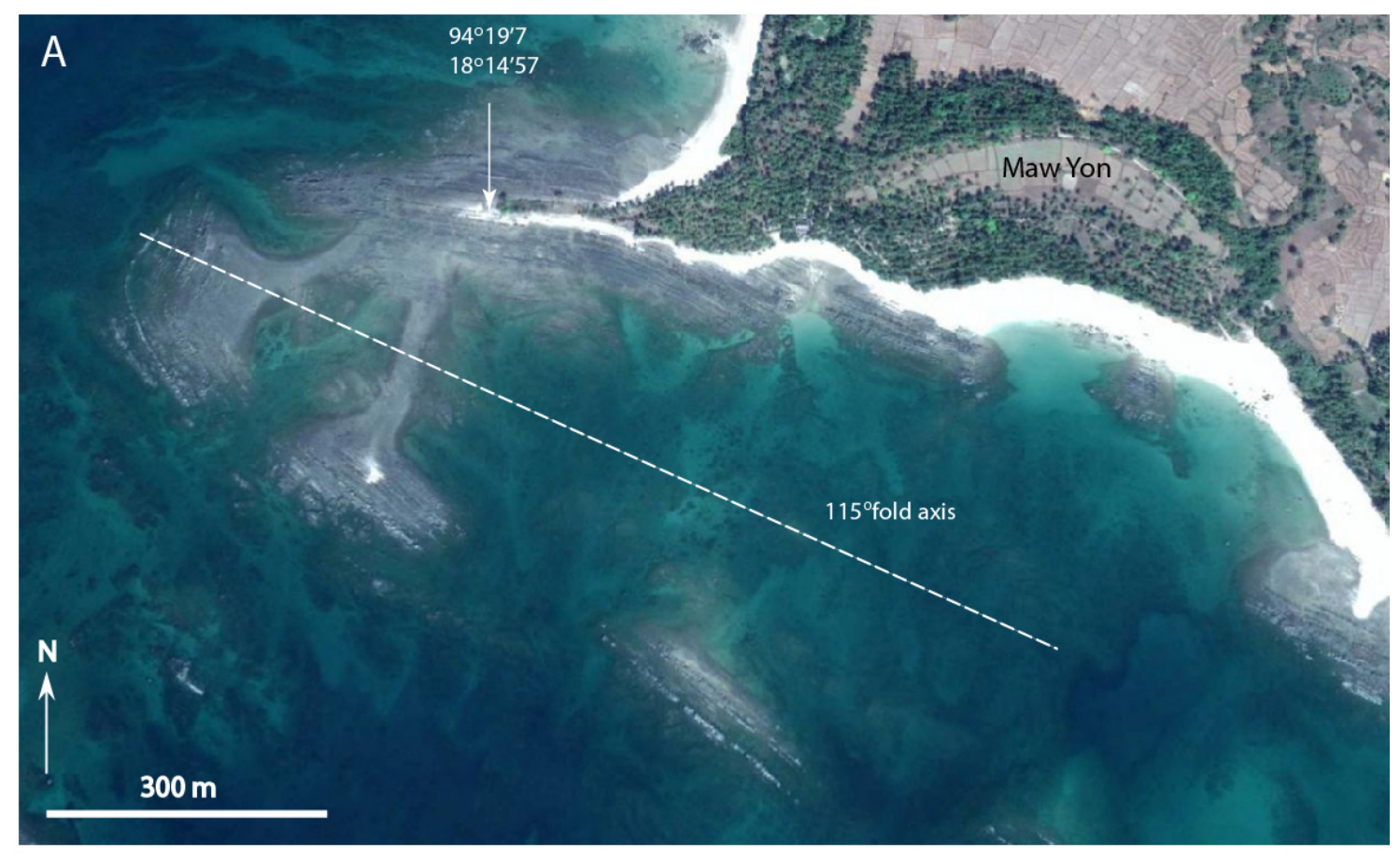

NW trending strike-slip fault?

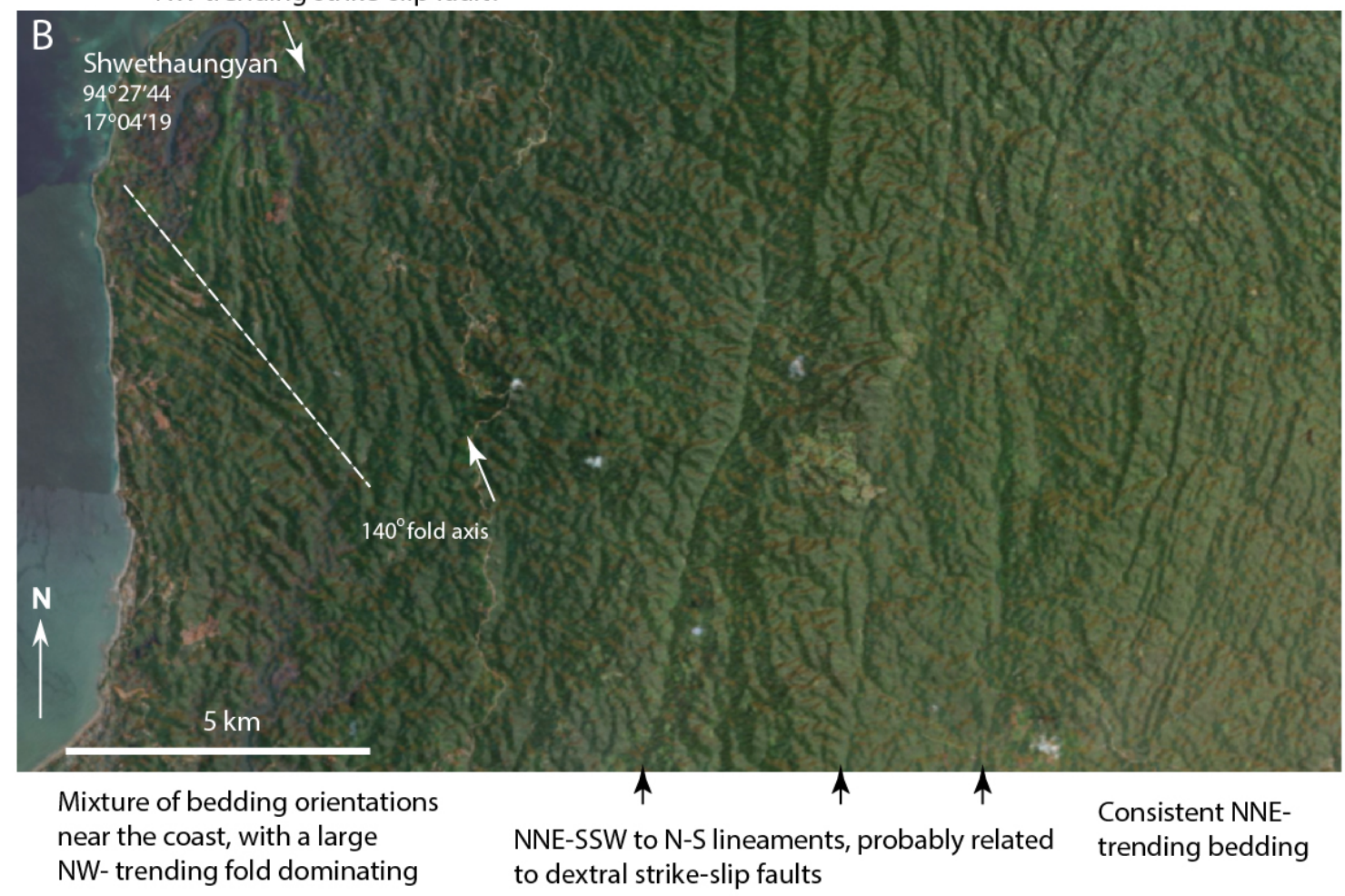

Fig. 26 


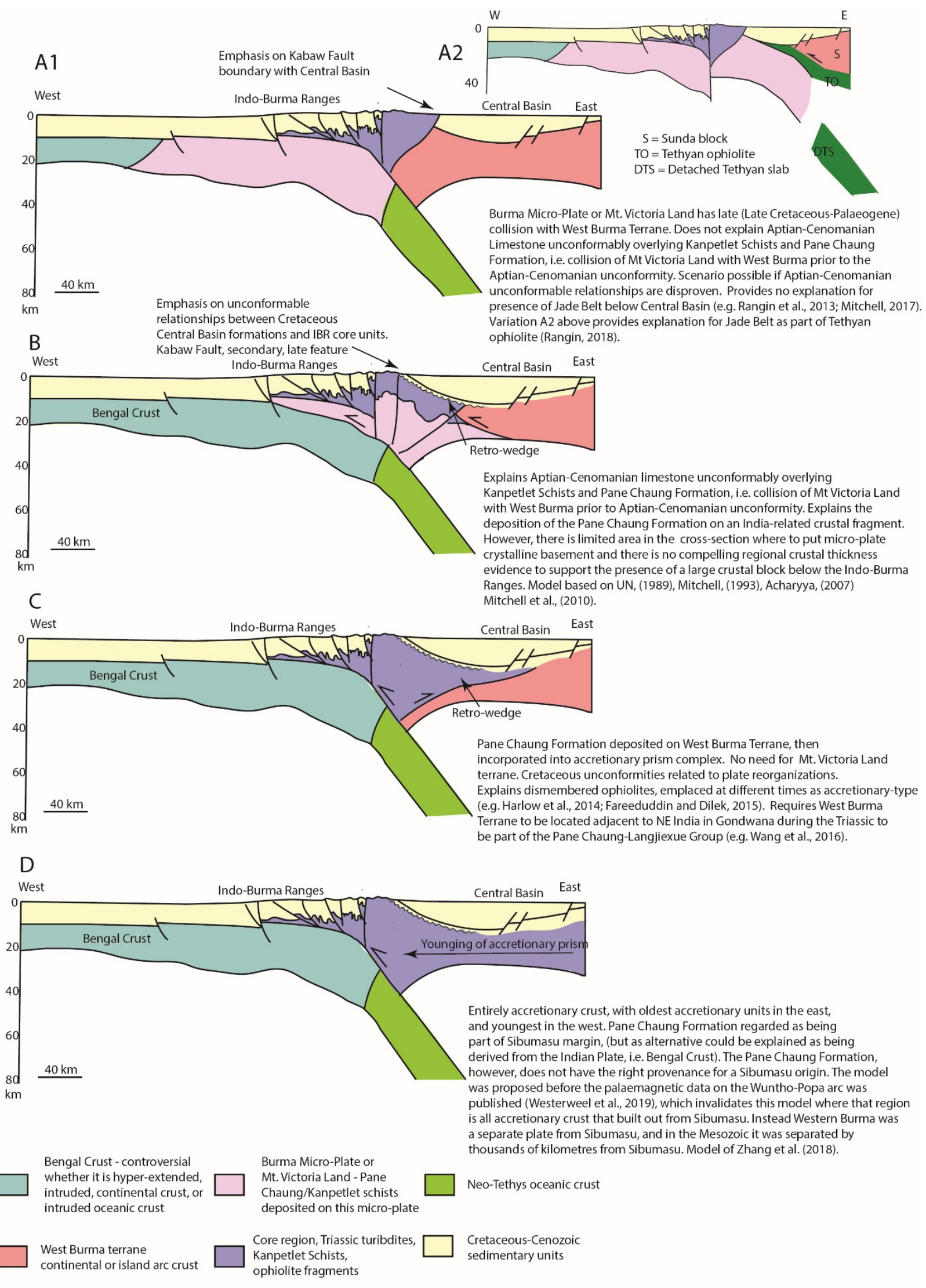




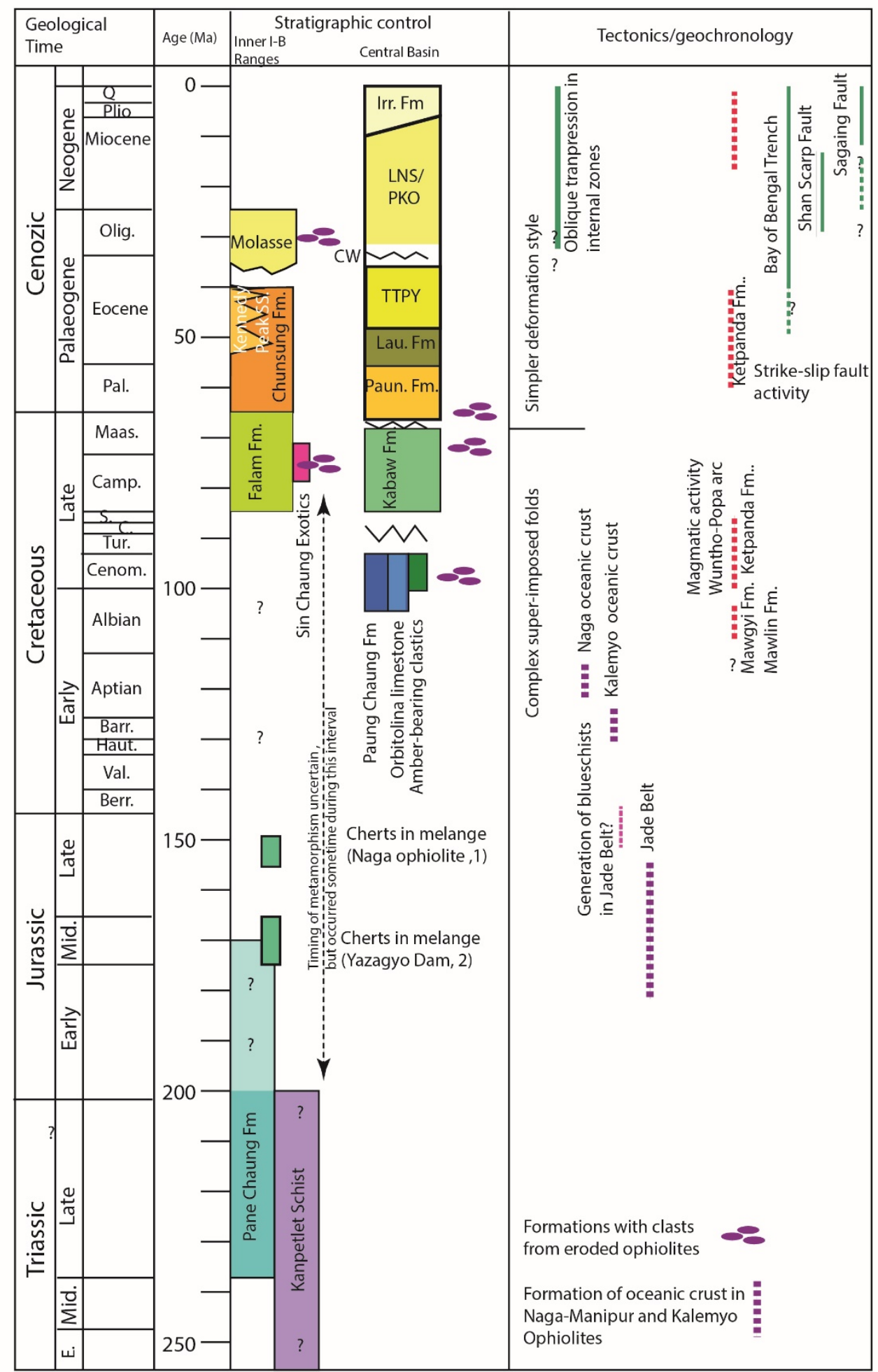

Fig. 28 

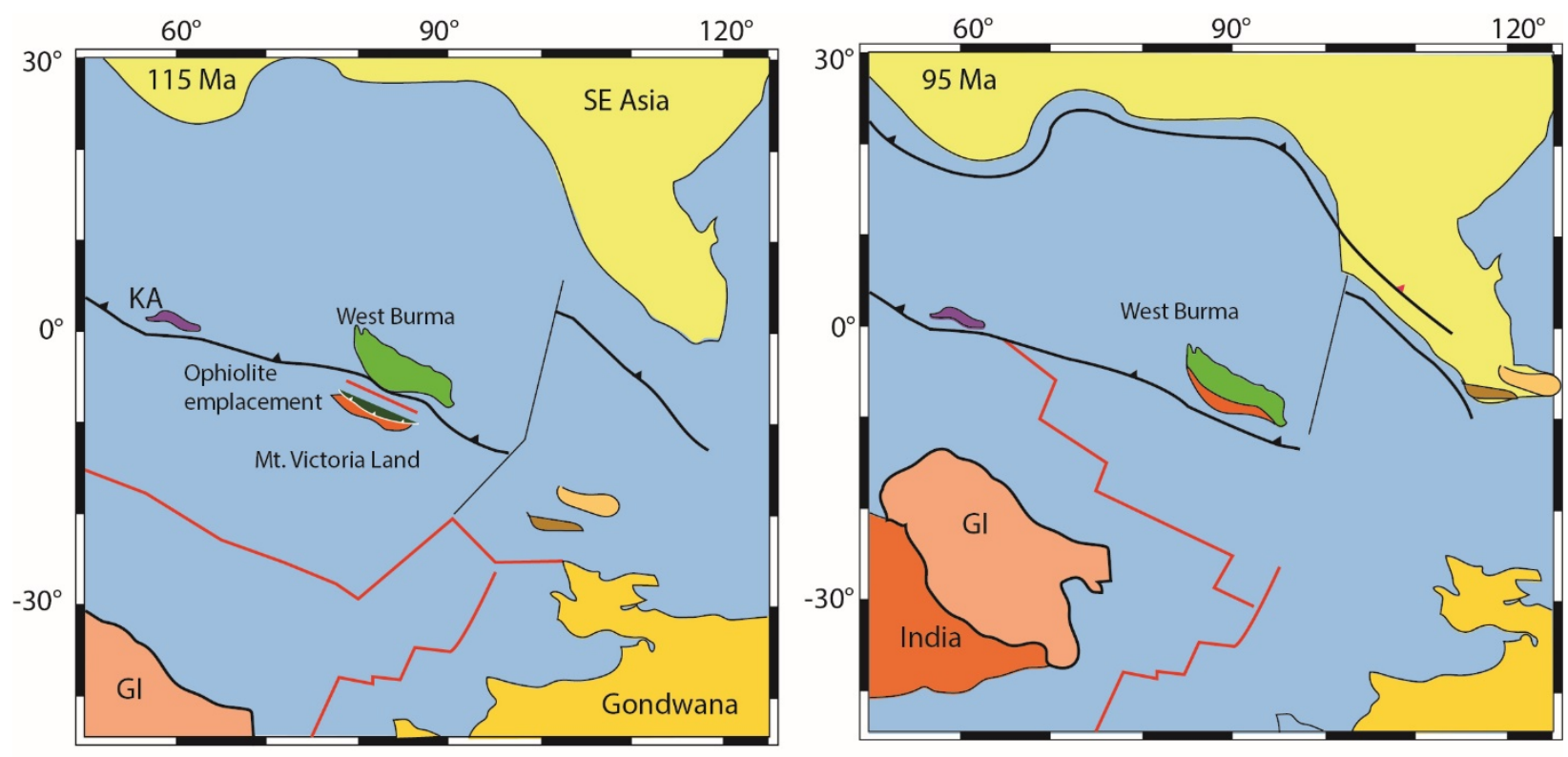

Fig. 29 
A) Late Triassic (200 Ma)

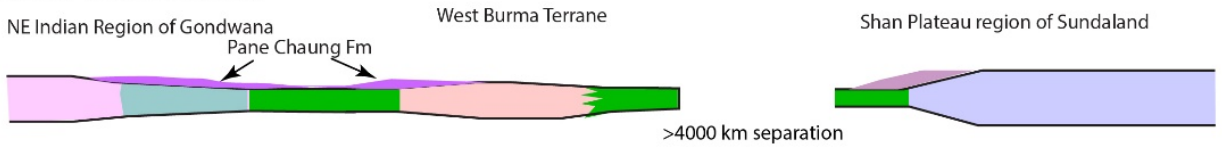

B) Early Cretaceous - $115 \mathrm{Ma}$

$28^{\circ} \mathrm{S}$ (NW corner)- $43^{\circ} \mathrm{S}$ (NE corner)

India starts to rift from Gondwana

Location uncertain

Metamorphism of Pane Chaung Formation to Kanpetlet Schists

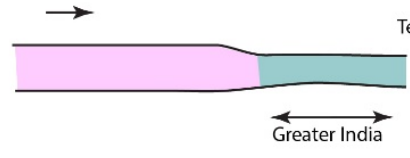

Emplacement of Kalemyo ophiolite (time of metamorphic sole)

thys Ocean

C) Mid-Cretaceous (100-95 Ma)

$22^{\circ} \mathrm{S}$ (NW corner)- $37^{\circ} \mathrm{S}$ (NE corner)

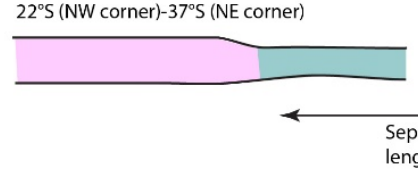

Tethys Ocean
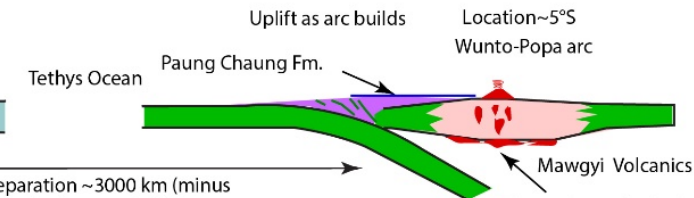

ength of greater India)

uplift

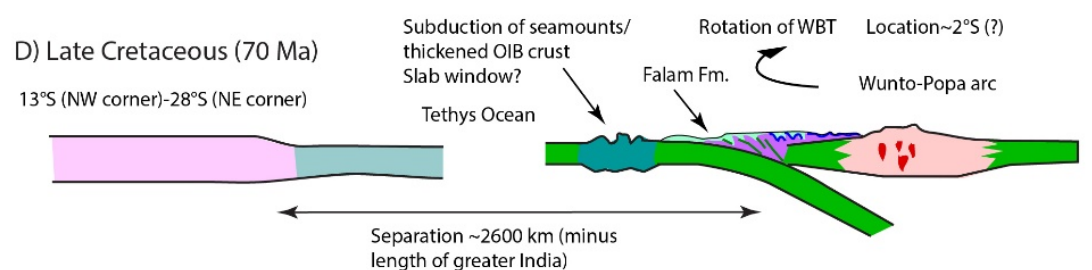

length of greater India)

E) Base Cenozoic (65 Ma)

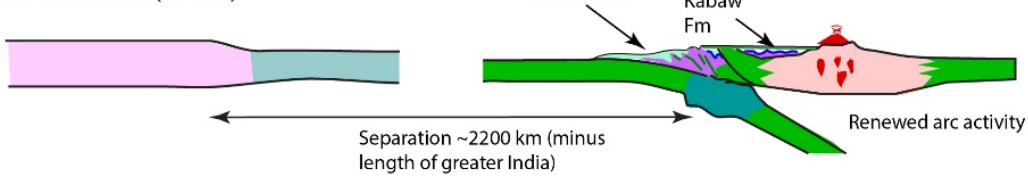

F) Late Eocene (40 Ma)

Location $4^{\circ} \mathrm{N}$ (?)

Shan Plateau region of Sundaland

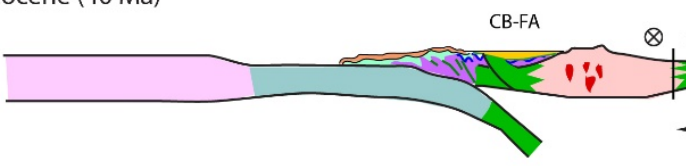

Separation $2100 \mathrm{~km}$

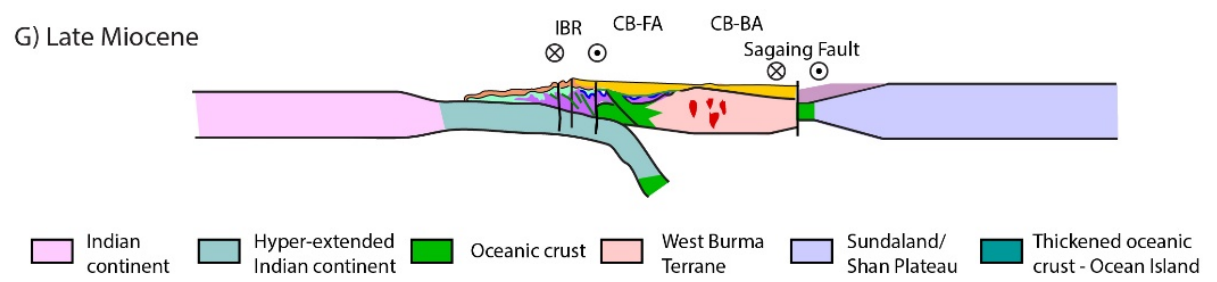



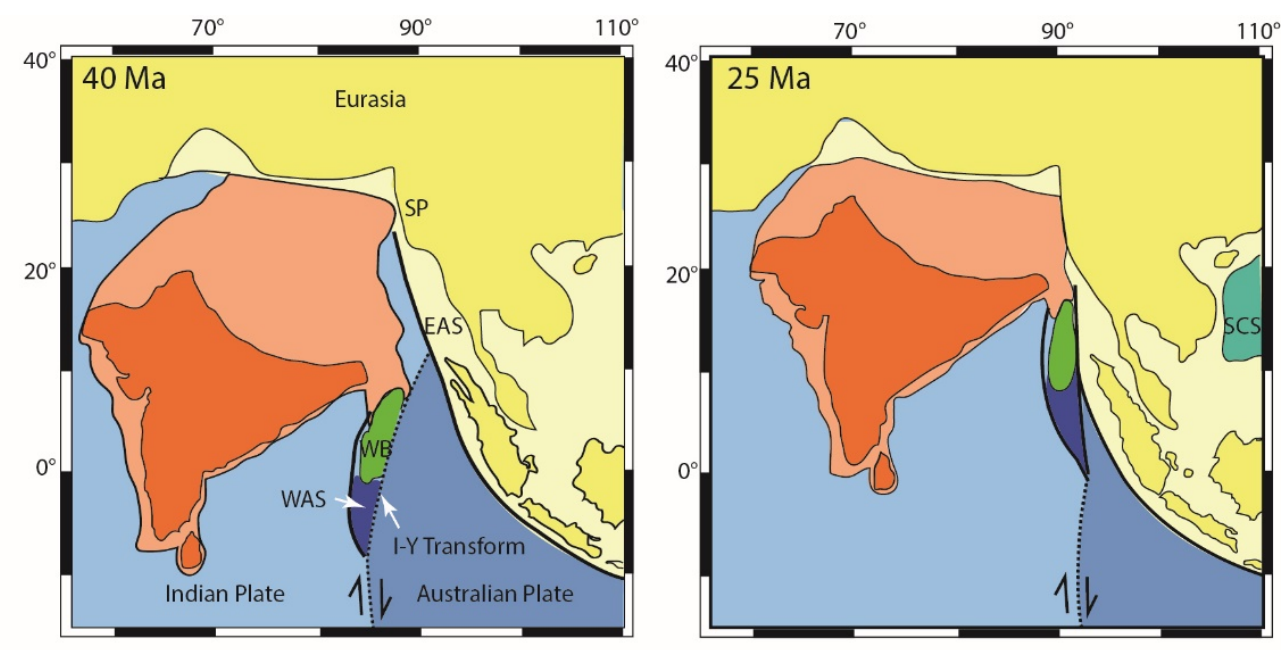

Fig. 31 


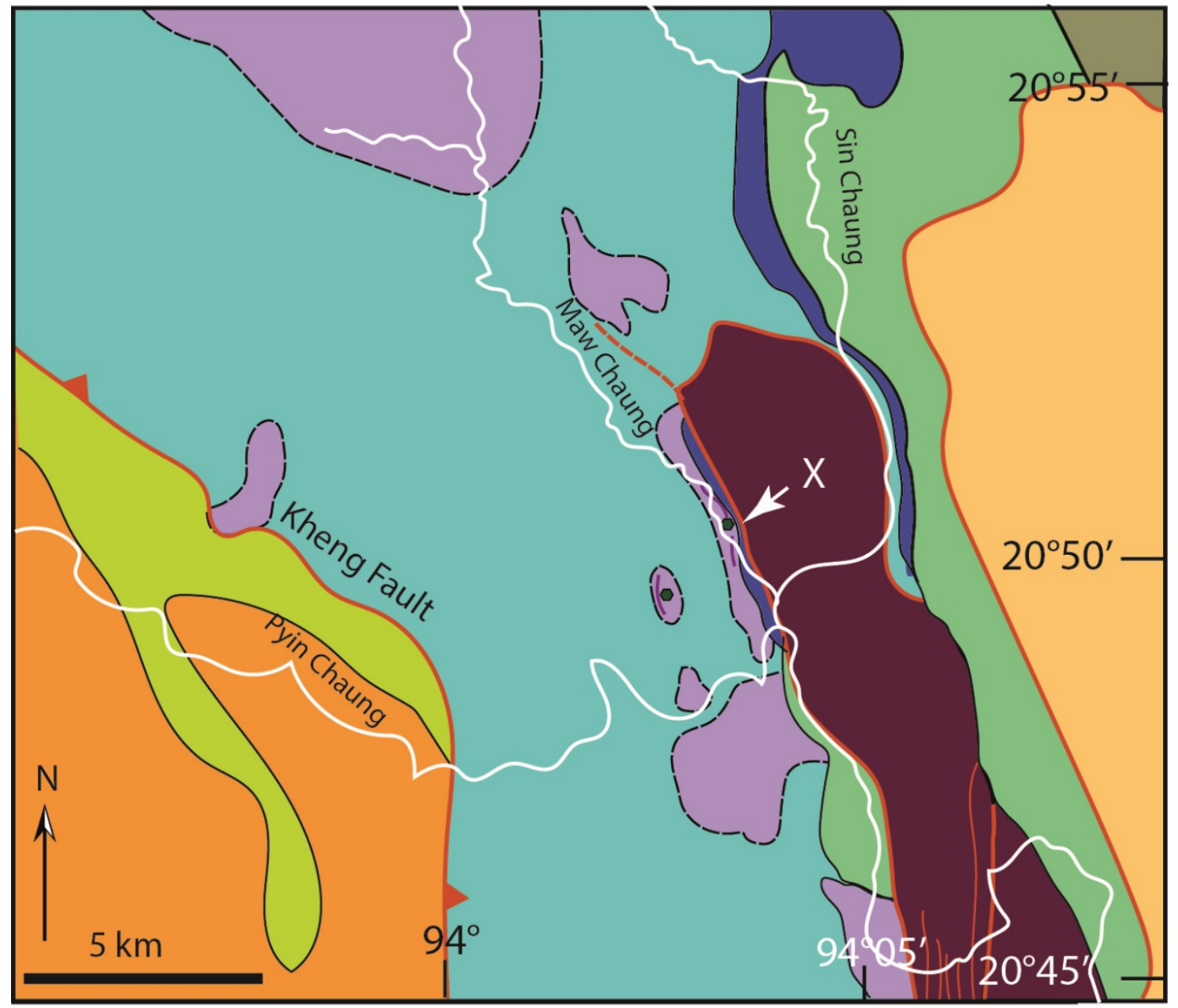

Indo-Burma Ranges

Cretaceous section underlying the Central Basin Central Basin

\begin{tabular}{|c|c|c|c|}
\hline $\begin{array}{l}\text { Chungsung } \\
\text { Formation }\end{array}$ & $\begin{array}{l}\text { Pane Chaung } \\
\text { Formation }\end{array}$ & $\begin{array}{l}\text { Kabaw } \\
\text { Formation }\end{array}$ & $\begin{array}{l}\text { Eocene (clastics) } \\
\text { Minbu Basin }\end{array}$ \\
\hline $\begin{array}{l}\text { Falam } \\
\text { Formation }\end{array}$ & $\begin{array}{l}\text { Kanpetlet } \\
\text { Schist }\end{array}$ & $\begin{array}{l}\text { Paung Chaung } \\
\text { Formation }\end{array}$ & Laungshe Shale \\
\hline $\begin{array}{l}\text { Exotics zone } \\
\text { (Melange) }\end{array}$ & $\begin{array}{l}\text { Stratigraphic } \\
\text { contact }\end{array}$ & Fault & $\begin{array}{l}\text { Serpentinite sheet } \\
\text { Pillow lava }\end{array}$ \\
\hline
\end{tabular}

Fig. A1 
Figure A2

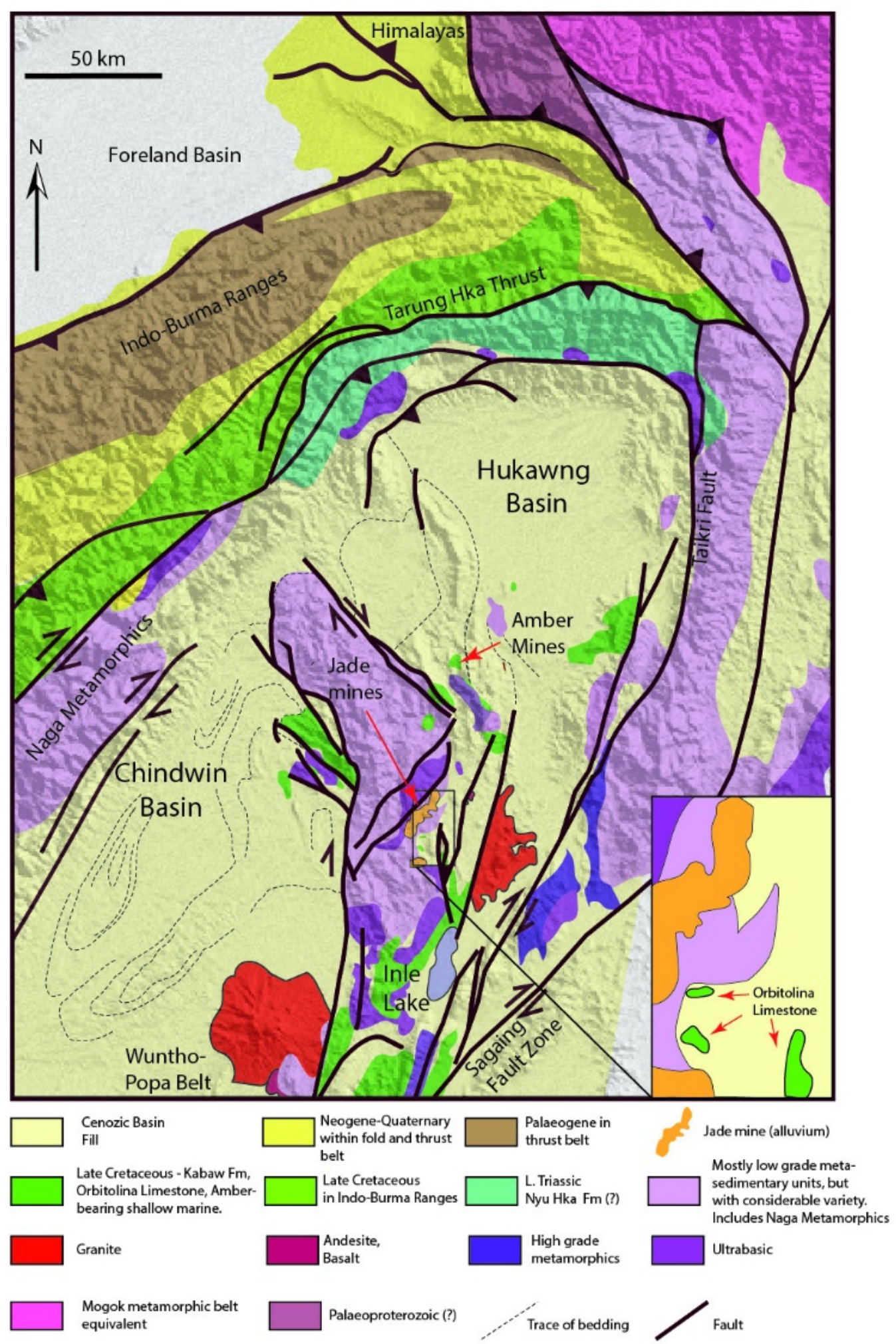




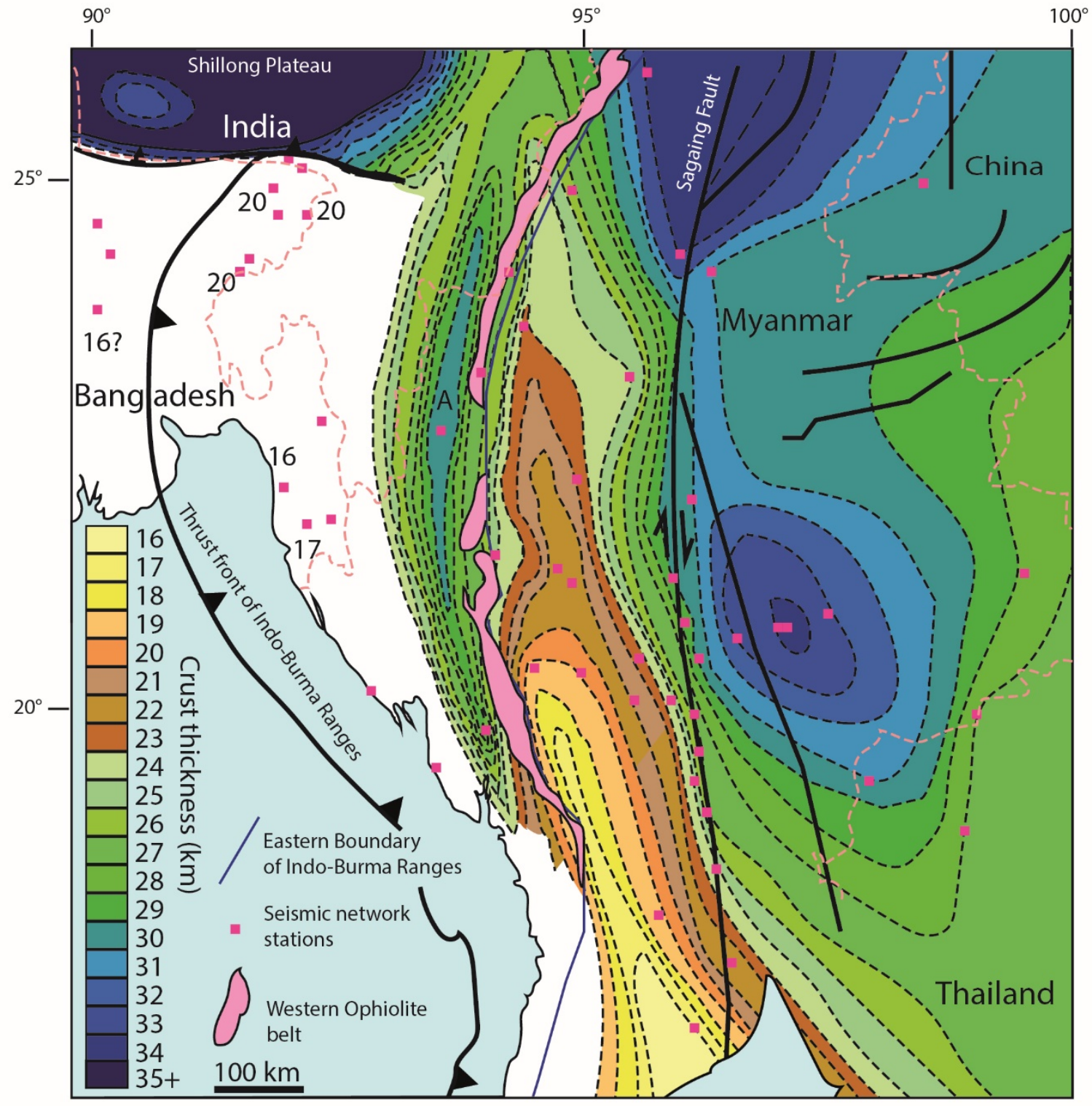

Fig. A3 
